ANDRÉ LUIZ MACHADO DE LIMA

\author{
A CHANCHADA BRASILEIRA E A MÍDIA: \\ O DIÁLOGO COM O RÁDIO, A IMPRENSA, A TELEVISÃO \\ E O CINEMA NOS ANOS 50
}

Dissertação de Mestrado

São Paulo

2007 


\title{
A CHANCHADA BRASILEIRA E A MÍDIA: \\ O DIÁLOGO COM O RÁDIO, A IMPRENSA, A TELEVISÃO \\ E O CINEMA NOS ANOS 50
}

\begin{abstract}
Dissertação apresentada à Escola de Comunicação e artes da Universidade De São Paulo para obtenção do título De Mestre em Ciências da Comunicação. Área de Concentração: Jornalismo.
\end{abstract}

Orientadora: Profa. Dra. Maria do Socorro Nóbrega

São Paulo 2007 
Termos de aprovação

Nome do Autor: André Luiz Machado de Lima

Título da Dissertação/ Tese:

A Chanchada Brasileira e a Mídia:

O diálogo com o Rádio, a Imprensa, a Televisão e o Cinema nos anos 50

Presidente da Banca:

Banca Examinadora:

Prof. Dr. Instituição

Prof. Dr. Instituição

Prof. Dr. Instituição

Prof. Dr. Instituição

Prof. Dr. Instituição

Aprovada em:

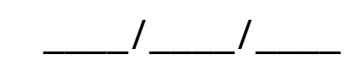


A meus pais,

Pedro Alves Pereira de Lima

e Iracilda Machado de Lima.

Aos tios Odette e Osvaldo. 


\section{AGRADECIMENTOS}

Ao Conselho Nacional de Desenvolvimento Científico e Tecnológico (CNPq) pela bolsa que me permitiu desenvolver diversas etapas desta pesquisa.

À estimada professora Dra. Maria do Socorro Nóbrega, pela orientação desta pesquisa com o devido rigor científico, pelo acolhimento nos momentos mais difíceis e pelo incentivo.

Ao professor Dr. José Luiz Proença, pelo acolhimento da pesquisa ao presidir a Banca Examinadora, em virtude da impossibilidade da presença da minha orientadora Profa. Dra. Maria do Socorro Nóbrega, que teve de se ausentar recentemente para seguir programas de estudos no exterior.

À professora Dra. Helena H. Nagamine Brandão e ao professor Dr. Eduardo Cunha Morettin, pelas valiosas contribuições no Exame de Qualificação.

À profa. Terezinha Tagé, pelo rico diálogo durante o estágio supervisionado em docência no Programa de Aperfeiçoamento do Ensino (PAE), que contribuiu para a ampliação do horizonte desta pesquisa.

A Guillermo Rivera, pelos incomensuráveis préstimos em diversas etapas finais do trabalho.

A Ângela Lima, pelo apoio e incentivo que vem me dedicando ao longo da vida.

A Guilherme Gadelha, pela compreensão dos momentos em que o isolamento se fez imperativo.

A Vanderlei Arruda, pela generosidade e paciência com os preciosos livros de Mikahil Bakhtin, pelo tempo necessário à conclusão da pesquisa.

A Helena Cardoso Freire, pela tradução do Resumo para o inglês.

A Ricardo Alexino, pelo pela sempre torcida para a ampliação do meu horizonte profissional como jornalista e pesquisador.

A Mariana Duccini, pelas ricas interlocuções como jornalista e pesquisadora, que contribuíram para o meu aprimoramento como pesquisador.

A Gustavo Souza, pelos livros essenciais de Jean-Claude Bernardet e pela leitura atenta do Quadro Teórico.

A Fernanda Martins, pela indicação das fundamentais bibliografias sobre narratologia. 
A Cid, pelo "livro chanchadesco".

A José H. Guimarães de Melo pelo profissionalismo na decodificação dos filmes de VHS para DVD.

A Paulo César, da área de Jornalismo da Pós-graduação da ECA, pelo profissionalismo e prontidão em diversas etapas de encaminhamento de projetos e relatórios.

E a todos os familiares e amigos que entenderam as minhas ausências e que torceram, de formas diversas, para a concretização desta pesquisa. 
LIMA, André Luiz Machado de. A chanchada brasileira e a mídia: o diálogo com o rádio, o cinema, a imprensa e a televisão nos anos 50. São Paulo, 2007, p. 177. Dissertação (Mestrado em Ciências da Comunicação). Escola de Comunicações e Artes, Universidade de São Paulo.

\section{RESUMO}

Esta pesquisa investiga o diálogo das produções cinematográficas cômicopopulares denominadas “chanchada brasileira" com os meios de comunicação nos anos 50. Tomando como referências teóricas o princípio dialógico de Mikhail Bakhtin, a Análise do Discurso e a Narrativa Cinematográfica, examina o diálogo dessas produções com a Imprensa, o Rádio, a TV e o próprio Cinema, mostrando as vozes que permeavam e retratavam a sociedade brasileira daquele período. Tais vozes respondem umas às outras ou polemizam entre si numa época em que a mídia passa por um processo de profundas transformações, rumo à lógica mercadológica da sociedade de consumo. Nesse sentido, este estudo busca evidenciar como se processa a interação das redes interdiscursivas entre os meios de comunicação.

Palavras-chave: dialogismo, interdiscurso, polifonia, narrativa, chanchada, paródia, ironia, carnavalização, mídia. 
LIMA, André Luiz Machado de. The Brazilian chanchada and the media: the dialogue with the radio, the cinema, the press and the television in the '50s. São Paulo, 2007, p. 177. Dissertation (MA in Communication Sciences). Escola de Comunicações e Artes, Universidade de São Paulo [School of Communication and Art, University of São Paulo].

\section{ABSTRACT}

This research aims to investigate the dialogue of the popular comical cinematographic productions called "Brazilian chanchada" with the means of communication in the 1950s. Taking as theoretical references Mikhail Bakhtin's dialogic principle, the Discourse Analysis and the Cinematographic Narrative, it examines the dialogue of those productions with the Radio, the Cinema, the Press and the TV, bringing to the surface the voices which pervaded and portrayed the Brazilian society of that period. Such voices respond to each other or raise polemics between themselves in an epoch when the media is undergoing a process of thorough transformation, en route to the marketing logics of the consumer society. In this sense, this study seeks to provide evidence of how the interaction of the interdiscursive networks among the means of communication is processed.

Key words: dialogism, interdiscourse, polyphony, narrative, chanchada, parody, irony, carnivalization, media. 
SUMÁRIO

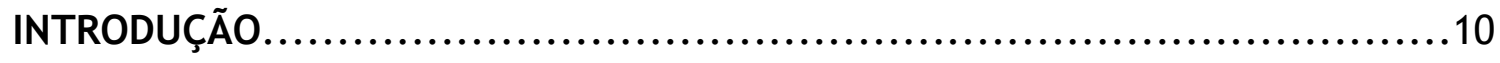

CAPÍTULO I - PERCURSO ANALÍTICO-METODOLÓGICO..........................16

1.1. TEMA E OBJETIVOS................................................... 16

1.2. REVISÃO DA LITERATURA.......................................... 17

1.3. QUADRO TEÓRICO DE REFERÊNCIA....................................39

1.3.1. Conceitos-chave da Análise do Discurso (AD) para a pesquisa......40

1.3.2. A dimensão dialógica do discurso...............................50

1.3.3. 0 discurso do cinema narrativo...................................57

1.3.4. Ponto de vista.................................................. 74

1.3.5. Espaço-tempo.................................................75

1.4. METODOLOGIA........................................................77

1.4.1. Constituição do corpus........................................77

1.4.2. Procedimentos de leitura das narrativas fílmicas..................83

CAPÍTULO II - A NARRATIVA CHANCHADESCA: DOS TEMAS RURAIS AO

COTIDIANO URBANO..................................................... 88

2.2.1. Narrativa clássica............................................92

2.2.2. Estrutura da narrativa chanchadesca.............................94

2.2.4. Dupla identidade.............................................96

CAPÍTULO III - A MÍDIA NA DÉCADA DE 50....................................98

3.1. A mídia rumo à ordem mercadológica...................................98

3.2. O rádio sob o controle do Estado populista.............................112

3.3. A chanchada e a burguesia do cinema paulista...........................119

3.4. A mídia impressa e a estigmatização da chanchada........................127 
CAPÍTULO IV - O DIÁLOGO DA CHANCHADA COM A MÍDIA NOS ANOS 50.....142

4.1. Nem Sansão nem Dalila, o rádio e a televisão.............................142

4.1.1. "Votai em Sansão, um homem de ação".........................142

4.2. A baronesa transviada, o cinema e a mídia impressa.....................161

4.2.1. "Cinema indígena"...........................................161

CONCLUSÃO..........................................................168

BIBLIOGRAFIA........................................................ 170

FILMOGRAFIA........................................................... 177 


\section{INTRODUÇÃO}

O fato é que entre as 'linguagens', quaisquer que elas sejam, são possíveis relações dialógicas (particulares), ou seja, elas podem ser percebidas como pontos de vistas sobre o mundo (Mikahil Bakhtin, 1993a, p. 99).

O cinema é o retrato em movimento de um país. Estudar o discurso cinematográfico como manifestação e representação social de uma época possibilita conhecer a produção de sentidos dos fatos históricos, sociais e culturais vivenciados no cotidiano e reconstituídos em enunciados que se articulam na linguagem fílmica.

Por se inscrever, essencialmente, em um meio de comunicação de massa, a imagem cinematográfica traz à cena a linguagem e os mitemas do povo que quase nunca a pintura, a narrativa literária nem a música dominantes incorporavam, induzindo, ao mesmo tempo, uma "outra articulação do popular com o tradicional, com o moderno, com a história e com a política” (García Canclini, 2000, p. 259).

Em outras palavras, o cinema, como expressão midiática, assimila os discursos correntes nas múltiplas vozes que dialogam no cotidiano e recria-os em 
enunciados verbo-visuais, em imagens cujos sentidos se revelam nas marcas das enunciações que abarcam o contexto que os motivaram e se completam nas relações que estabelecem com os discursos socialmente em voga no momento de sua produção.

A articulação do popular com o culto, tal como assinala Aníbal Ford (1988), é uma característica própria da mídia, que se encarrega de toda uma zona malvista pela cultura culta (aventura, folhetim, mistério, festa, humor) para incorporá-la à cultura de massas.

No âmbito desta pesquisa, faz-se necessário pontuar que nos apropriamos da noção que delimita o erudito do popular justamente por nos situarmos no contexto sócio-histórico dos anos 50, no qual identificamos uma cisão entre cultura alta e baixa na esfera da produção cultural.

Contudo, entendemos que a clássica oposição maniqueísta entre cânone e cultura popular, que perdurou nos últimos cinqüenta anos como paradigma central dos estudos literários, tornou-se atualmente insustentável. Tal noção começou a ser revista a partir da década de 80 , com as abordagens teóricas do desconstrutivismo e do pós-estruturalismo que sentenciaram o fim da separação entre os pólos cultura alta e baixa. 
A separação a qual nos referimos evidencia-se, precisamente, em meio à efervescência cultural no cenário urbano carioca e paulista da década de 50 , na qual se circunscreve com toda força a realização de filmes de diversos gêneros, das comédias musicais chanchadescas a melodramas capitaneados pela produtora paulista Vera Cruz.

É nesse cenário de ebulição cinematográfica, com tendências e enfoques narrativos opostos, em meio à cisão na esfera da produção cultural e à consolidação de uma sociedade de consumo, onde o presente estudo se concentra.

0 interesse em desenvolver esta pesquisa originou-se da constatação de que existe uma lacuna nos estudos sobre a chanchada brasileira, gênero cômicopopular de cinema estigmatizado como subproduto cultural pela elite formadora de opinião (imprensa, intelectuais, cineastas e produtores), particularmente nos anos 50.

Desse modo, a investigação dedica-se a um tema ainda pouco explorado nos estudos a respeito da chanchada: a relação dialógica dos filmes chanchadescos (em princípio posicionados como subprodutos culturais) com a mídia de sua época (em princípio posicionados como veículos ideológicos de uma sociedade de consumo emergente). Entre esses dois vastos espaços discursivos, transitam vozes que se entrecruzam e se fazem presentes nas marcas 
enunciativas do popular gênero cinematográfico. Nesse sentido, o estudo busca evidenciar como se processa a interação das redes interdiscursivas entre o rádio, o cinema, a televisão e a imprensa.

Para tanto, centramos a pesquisa na década de 50 , por se tratar de um período no qual as produções chanchadescas consolidaram-se como gênero cinematográfico cômico-popular, alcançando um novo patamar estéticonarrativo. Por sua vez, os meios de comunicação avançam, naquela década, numa transição rumo à lógica mercadológica decorrente da ascensão da sociedade de consumo.

Segundo Ortiz (2001) há, nos anos 50, a incipiência de um mercado de bens simbólicos, em um período descrito como momento de modernização da mentalidade empresarial e das instituições culturais. Este aspecto de mercantilização iminente está estreitamente associado à massificação dos meios de comunicação, que ampliam sua difusão à proporção que o capitalismo industrial cresce em centros urbanos como Rio de Janeiro e São Paulo.

Apesar de o gênero chanchada também ter-se referido à mídia em filmes produzidos nos anos 40 e 60 (este último período com destaque especial para a televisão), privilegiamos o recorte na década de 50, em razão do crescimento vertiginoso dessas produções em relação aos outros períodos ${ }^{1}$.

\footnotetext{
1 Nos anos 40, a chanchada passa a ser produzida em escala industrial pela Atlântida Cinematográfica, a maior companhia do gênero, conquistando o público no final da década. Nos
} 
O salto no volume de produção de filmes chanchadescos nos anos 50 foi uma conseqüência direta dos investimentos realizados no setor na década de 40 , quando se tentou construir uma cinematografia nacional. O maior incremento na produção ocorreu na segunda metade da década de 50 , como confirmam os dados colhidos por Sérgio Augusto: “[...] desde 1956, o número de fitas nacionais estreadas aumentou (de 32 para 38, em 1957, atingindo a marca de 40 em 1958) [...]" (1989, p. 64-65).

As chanchadas dos anos 50, portanto, constituem-se em um rico material de análise, pois retratam um Brasil em transição, que abdica os valores de uma sociedade pré-industrial e ingressa na ciranda do consumo de bens materiais e simbólicos, cujo modelo teria nos meios massivos (imprensa, rádio, cinema e televisão) a sua principal sustentação.

Ao privilegiarmos como objeto de estudo o discurso de crítica social presente nos filmes chanchadescos, observamos que, entre os segmentos da elite cultural levados criticamente às telas pela chanchada, junto com as instituições que estes representam (o político e a política, o industrial e a fábrica, a grã-fina e os institutos de beleza, o patrão e o escritório), destacam-se os meios de

anos 50, as chanchadas atingem o pleno domínio narrativo e o apogeu comercial ao ampliar o número de espectadores nas salas de exibição. Na década de 60, apesar da maioridade dessas produções, o público esvai-se das salas de exibição. A maioria dos autores que se dedicaram ao estudo da chanchada, atribuem o desgaste sofrido pelo gênero à expansão da televisão e à desumanização das metrópoles brasileiras, marcadamente a partir do surto desenvolvimentista de JK, na segunda metade dos anos 50. 
comunicação como protagonistas de destaque no popular gênero cinematográfico. Nas chanchadas, identificamos a presença do rádio e do locutor/cantor, do próprio cinema e do diretor do estúdio, da imprensa e do jornalista, da televisão e do apresentador de TV, entre outras personagens desse universo midiático representado pelo gênero.

Essa percepção nos motivou a investigar, numa perspectiva dialógica, o discurso da chanchada a respeito da mídia, com o objetivo de evidenciar as articulações existentes entre as comédias musicais denominadas chanchadas e o novo modelo de mídia que se desenha a partir dos anos 50, atrelado à lógica comercial. Nesse sentido, buscamos evidenciar como se processa a interação das redes interdiscursivas entre os meios de comunicação.

Para analisar essa interação na materialidade lingüística verbal e nãoverbal das chanchadas, a pesquisa apoiou-se em duas grandes vertentes dos estudos do discurso: a Análise do Discurso de linha francesa (AD) e a teoria do discurso da narrativa, centrando as reflexões em torno da dimensão dialógicadiscursiva, postulada por Mikahil Bakhtin, que norteia todo o estudo.

O Capítulo I - Percurso Analítico-Metodológico apresenta os conceitos da $A D$, do dialogismo e do cinema narrativo que se articulam com os objetivos da pesquisa. Descreve, por conseguinte, a metodologia empregada na constituição e 
leitura do corpus, a qual privilegia uma análise do discurso chanchadesco em três níveis: verbal, visual e sonoro.

No Capítulo II - A Narrativa chanchadesca: dos temas rurais ao cotidiano urbano, o estudo traça um panorama da estrutura narrativa do gênero.

O Capítulo III - A Mídia na Década de 50 posiciona os meios de comunicação (rádio, cinema, imprensa e televisão) num período histórico que é marcado pelo crescimento da publicidade, num contexto de consolidação da sociedade de consumo.

Por fim, o Capítulo IV - O Diálogo da Chanchada com a Mídia nos Anos 50 examina a interação dos filmes chanchadescos com o rádio, o cinema, a imprensa e a televisão, com base em duas chanchadas recortadas do corpus: Nem Sansão, nem Dalila (1954) e A baronesa transviada (1957).

\section{CAPÍTULO I - PERCURSO ANALÍTICO-METODOLÓGICO}

\section{TEMA E OBJETIVOS}

Com base na dialogia entre cinema popular e mídia, esta pesquisa tem como principal objetivo estudar o diálogo da chanchada brasileira com a mídia radiofônica, impressa (jornal e revista), eletrônica (televisão) e 
cinematográfica no contexto socio-histórico dos anos 50 , buscando identificar como se estabelecem as redes interdiscursivas entre esses meios de comunicação.

Partindo do pressuposto de que a chanchada foi estigmatizada como subproduto cultural por esses meios de comunicação, o presente estudo procura analisar o discurso dialógico chanchadesco sobre a mídia naquele período. Nessa perspectiva, esta pesquisa pretende examinar a imprensa, o rádio, a televisão e o próprio cinema como vozes que se fazem presentes no texto chanchadesco; busca examinar em que período socio-histórico esse diálogo foi mais recorrente, sob que ponto de vista esse diálogo se processou, quais vozes permeiam esse diálogo e quais são as similitudes entre os diálogos estabelecidos pela chanchada com cada meio e qual discurso se apresenta como eixo central nessa rede interdiscursiva.

A pesquisa se propõe, enfim, a examinar o discurso chanchadesco sobre os meios de comunicação dos anos 50 , com base nos conceitos da Análise do Discurso $(A D)$ e da narratologia, apoiando-se, fundamentalmente, nos princípios dialógico e carnavalesco do pensador russo Mikhail Bakhtin.

\section{REVISÃO DA LITERATURA}

A literatura específica sobre o gênero chanchada, apesar de não ser escassa, não apresenta a devida amplitude que o tema merece. Tal como 
mencionamos na Introdução, existe uma lacuna nos estudos sobre a chanchada, uma vez que diversos aspectos sobre tão vasta produção cinematográfica nacional ainda não foram investigados ou devidamente revisados, a exemplo da recepção desses filmes como fenômeno midiático ou do estigma de humor ingênuo e produto mal-acabado que insiste em perdurar sobre o gênero até os dias atuais.

Não cabe no âmbito desta pesquisa enumerar as diversas questões que podem ser suscitadas como instrumentos de reflexão com base no gênero chanchadesco, mas cabe reiterar que a motivação desta dissertação parte do pressuposto de que existe uma relação dialógica da chanchada com a mídia de sua época, a partir do qual lançamos luz sobre um tema ainda pouco valorizado como objeto de investigação no universo acadêmico.

Há, contudo, relevantes dissertações de mestrado, pesquisas e livros que se dedicaram ao estudo do gênero chanchada numa perspectiva socio-histórica, tais como: O tostão furado: um estudo sobre a chanchada, de Miguel W. Chaia ${ }^{2}$; A chanchada no cinema brasileiro, de Afrânio M. Catani e José I. de Melo Souza ${ }^{3}$; “A chanchada e o cinema carioca (1930-1955)" e "From High Noon to Jaws: Carnival and parody in brazilian cinema", capítulos de João Luiz Vieira, respectivamente, nos livros História do cinema brasileiro ${ }^{4}$ e Brazilian Cinema ${ }^{5}$;

\footnotetext{
${ }^{2}$ Dissertação de mestrado apresentada à Faculdade de Filosofia, Letras e Ciências Humanas da USP em 1980.

${ }^{3}$ Livro publicado pela editora Brasiliense em 1983.

${ }^{4}$ Livro organizado por Fernão Ramos e lançado pela Art Editora em 1987.
} 
Este mundo é um pandeiro: a chanchada de Getúlio a JK, de Sérgio Augusto ${ }^{6}$; 0 mundo como chanchada: cinema e imaginário das classes populares na década de 50, de Rosangela de Oliveira Dias ${ }^{7}$; Cinema popular brasileiro e a representação da malandragem: de Oscarito a Mário Fofoca, a chanchada e a telenovela humorística, pesquisa coordenada por Afrânio Mendes Catani ${ }^{8}$; e Paródia $e$ chanchada: imagens do Brasil na cultura de classes populares, de William Reis Meirelles ${ }^{9}$. Autores como Alex Viany (1959), Paulo Emílio Salles Gomes (1980) e Jean-Claude Bernardet (1979), embora não tenham estudado especificamente a chanchada, dedicaram algumas reflexões ao tema em artigos ou ensaios relacionados com o cinema nacional.

Tarefa difícil é demarcar qual autor empreendeu a primeira revisão significativa sobre o estigmatizado filme chanchadesco. O livro Introdução ao cinema brasileiro (1959), de Viany, uma pesquisa histórica do cinema nacional baseada em vasta documentação, é considerado pela maioria dos autores como o marco inicial de uma releitura do gênero chanchada. Diz esse autor sobre o cômico cinema popular:

Não obstante seus óbvios defeitos, a chanchada serviu para provar que o filme brasileiro podia ser um bom negócio e, pondo na tela os trejeitos e o linguajar da gentinha do Rio de Janeiro, acabou de vez com a lenda, criada por alguns tantos filmes sérios, de que 0

\footnotetext{
${ }^{5}$ Livro organizado por Robert Stam e Randal Johnson em 1995.

${ }^{6}$ Livro publicado pela Companhia das Letras em 1989.

7 Dissertação de mestrado apresentada ao Instituto de Ciências Humanas e Filosofia da Universidade Federal Fluminense, Niterói, em 1990, e transformada em livro em 1993.

${ }^{8}$ Relatório final de pesquisa coordenada por Afrânio Mendes Catani no Centro de Estudos LatinoAmericanos sobre Comunicação (Celacc), vinculado à Escola de Comunicações e Artes da Universidade de São Paulo, e apresentado ao CNPq em 1998.

9 Livro lançado pela editora Eduel em 2005, escrito por Meirelles com base na dissertação de mestrado Cinema e história, o cinema brasileiro nos anos 50, apresentada à Universidade Estadual de São Paulo (Unesp) de Assis, em 1989.
} 
brasileiro não sabia comportar-se defronte da câmara e de que a língua portuguesa não prestava para os diálogos cinematográficos (1959, p.133-134).

Tal reconhecimento, sem dúvida, está associado ao fato de o intelectual Viany ter conhecido, na prática, o modo como se realizava uma chanchada. Em 1953, criou o argumento, o roteiro e dirigiu Agulha no Palheiro, produzida pela Flama, um sucesso de bilheteria.

No ensaio “Cinema: trajetória no subdesenvolvimento" (1980), Salles Gomes reconhece que a produção ininterrupta de filmes musicais e de chanchada durante cerca de vinte anos, ou a combinação de ambos, trata-se de um marco cinematográfico que se desenvolveu no Rio de Janeiro, a partir dos anos 40, contrariamente aos interesses dos grupos estrangeiros. O autor observa nas chanchadas uma característica eminente de brasilidade:

\begin{abstract}
[as chanchadas são] [...] modelos de espetáculos que possuem parentesco em todo o Ocidente, mas que emanam diretamente de um fundo brasileiro constituído e tenaz em sua permanência. A esses valores relativamente estáveis os filmes acrescentavam a contribuição das invenções cariocas efêmeras em matéria de anedota, maneira de dizer, julgar e de se comportar, fluxo contínuo que encontrou na chanchada uma possibilidade de cristalização mais completa do que anteriormente na caricatura ou no teatro de variedades (Salles Gomes, 1980, p. 95).
\end{abstract}

As revisões que tratam do tema com mais especificidade e consolidam a noção de chanchada como um gênero cômico cinematográfico ampliam-se a partir do final da década de 70 e início dos anos 80 . 0 livro Filmusical brasileiro e chanchada (1977), de Rudolf Piper, é considerado uma referência pelo seu pioneirismo; no entanto, a tentativa do autor de realizar uma análise histórica e 
cultural mais aprofundada da chanchada resulta numa abordagem factual, ilustrada por cartazes e cenas de filmes, imagens alinhavadas por um discurso, por vezes, opinativo. Cabe, contudo, avaliarmos a leitura "histórica" que o autor dedica à comédia musical.

Logo nas primeiras linhas do livro, Piper escreve em tom opinativo que, “na esteira da onda de nostalgia, revalorizou-se, por fim, algo de profundamente brasileiro: a chanchada. E nem poderia ser diferente, porque o público já estava cansado dos canastrões, das Marilyns e dos Glenn Miller de origem importada" (1977, p. 7).

Para Piper, a fita ${ }^{10}$ Nhô Anastácio chega de viagem ${ }^{11}$, comédia de 15 minutos realizada em 1908, pode ser considerada "a primeira chanchada nacional" ou "pelo menos [...] a predecessora do gênero" (1977, p. 11). Nessa fita, o autor observa que já estão presentes

\begin{abstract}
as linhas mestras que a chanchada herdou do teatro cômico: o trapalhão (Nhô Anastácio), o turismo (paisagens do Rio, que sempre 'embelezaram' os argumentos das chanchadas), o namoro, a música (indiretamente representada pela cantora, já que o filme era mudo), a confusão (originada pela vinda da esposa) e o final feliz, que voltaria a colocar tudo nos eixos, eliminando a tensão (1977, p. 11).
\end{abstract}

\footnotetext{
${ }^{10}$ Assim se denominavam os curtos filmes realizados nos início do século XX, entre as décadas de 1910 e 1920.

11 Nhô Anastácio narra as peripécias de um mulato que resolve passear no Rio de Janeiro e enamora-se de uma cantora, situação que se complica com a súbita chegada de sua esposa. Exibido no Grande Cinematógrapho Pathé, foi filmado por Júlio Ferraz e interpretado por José Gonçalves Leonardo.
} 
Depois dessa comédia cinematográfica, o autor aponta o lançamento de outras, inclusive as de "tipo carnavalesco", como Pela vitória dos clubes brasileiros (1909) e Pega na chaleira (1909), e "comédias de costumes", como Os capadócios da Cidade Nova (1909) e O nono mandamento (1909). Piper identifica, em 1911, uma importante "chanchada": As aventuras de Zé Caipora, baseada na história em quadrinhos de Ângelo Agostini para o jornal O malho.

A nosso ver, Piper indiferencia essas produções por não demarcá-las numa periodização ou, antes, delimitá-las em filmes cantantes ou filme-revistas, pois as considera ora "comédias de costumes", ora "filmes carnavalescos", ora “chanchadas". Para os estudiosos da história do cinema nacional, a fita Nhô Anastácio chegou de viagem é considerada a primeira comédia musical do cinema brasileiro. Sérgio Augusto a aponta como "uma remota precursora da chanchada, o território favorito dos conflitos mais pitorescos entre a cidade e o campo e marido e mulher" (1989, p. 85).

Com efeito, o cinema brasileiro chega à sátira de costumes, comum no teatro de revista, dois anos depois da exibição de Nhô Anastácio, com o lançamento do filme-revista Paz e amor, no centro do Rio de Janeiro, em abril de 1910. Entre a estréia do gênero filme-revista e o despontar do gênero chanchada, há o florescimento do filme musical carnavalesco, com mais freqüência na década de 30. 
Abordando o tema com o rigor de uma investigação, a dissertação $O$ tostão furado (1980), de Chaia, desenvolve a hipótese de que há uma tensão interna nos filmes chanchadescos que se processa em dois níveis ${ }^{12}$ : o nível da totalidade fílmica, no qual Chaia circunscreve a chanchada como um produto da indústria cultural cujo discurso fílmico estrutura-se com mensagens homogêneas repetidas regularmente, e o nível das unidades narrativas mínimas e personagens, que têm significado no conjunto do filme e na relação que estabelecem entre si, podendo assumir uma relativa autonomia. Nessas unidades a chanchada apresenta sua verve cômica-caricatural.

No nível da totalidade fílmica, Chaia identifica uma temática geral baseada na realização de um desejo/objetivo por uma personagem principal em decorrência de um lance de sorte (prêmio, herança, sorteio, sucesso no mundo artístico). Entre o protagonista e seu objetivo intercalam-se encrencas, conflitos, vilões que atrapalham, amigos que ajudam. O dinheiro é o artifício mais viável para a realização desse projeto, e é a partir desse meio que o autor observa a polarização entre incluídos e excluídos da sorte, entre rico e pobre. 0 mundo artístico como sinônimo de sucesso, as relações campo-cidade e atrasomodernidade, o caipira e o homem urbano são as características destacadas pelo autor como constitutivas da chanchada nesse nível geral.

\footnotetext{
${ }^{12}$ Conceitos desenvolvidos por Christian Metz em A significação no cinema. São Paulo: Perspectiva, 1972.
} 
No nível das unidades narrativas e personagens, Chaia elenca três categorias relacionadas com a vertente cômico-caricatural: 1) preocupação com a sobrevivência e com o cotidiano; 2) ênfase na origem rural que engendra uma série de relações de vizinhança e amizade; 3) contato com valores urbanos. Segundo o autor, nesse nível cômico-caricatural, a chanchada apresenta sua característica para a avaliação e crítica à situação vivida pelas personagens que sobrevivem à sua maneira, agem e falam com “maior grau de liberdade”.

Ao articular esses dois níveis, o autor define a chanchada como produto da indústria cultural que se sustentou em um contexto socio-histórico marcado pelo projeto desenvolvimentista com dependência do capital estrangeiro. Nesse contexto, em que há uma emergência de grupos populares no espaço urbanoindustrial, a estrutura de classes é tênue. Chaia aponta que a chanchada retratou justamente a parcela da população excluída do espaço de participação política, social e econômica. 0 autor sustenta que as personagens

não se enquadram no padrão burguês estabelecido para 0 desenvolvimento urbano-industrial vigente na sociedade brasileira nas décadas de 50 e 60 . São seres que não participam do pacto social estabelecido entre grupos sociais naqueles anos. [...] A chanchada trata dos simplórios que não entram no jogo desenvolvimentista. Vivem sem um projeto mais significativo do que aquele de se adaptar ao dia-a-dia, de partilhar um mundo urbano incompreensível na sua realidade socioeconômica. Uma boa forma de se apreender e tentar compreender esta realidade é através da comicidade e do caricatural [...] (1980, p. 96-97).

O trabalho de Dias, O mundo como chanchada (1993), toma o filme chanchadesco como um veículo de interpretação do imaginário das classes 
populares $^{13}$ brasileiras na década de 50. A autora tem como pressuposto que a grande popularidade das chanchadas reside no fato de estas retratarem por meio da sátira e do deboche as mazelas da sociedade brasileira, o mundo cultural das populações que formavam o seu público em potencial. “Não ficávamos passivos diante do cinema que nos era imposto. Oscarito, Grande Otelo e outros artistas das chanchadas lavavam a alma da população mais pobre ao tornarem-se verdadeiros heróis" (1993, p. 10).

Ao representar esse mundo de forma criativa e personalíssima pela interpretação dos atores, a chanchada mescla personagens com artistas que conquistam a empatia do público pelo gestual derivado do circo e do humor revisteiro, elementos familiares em razão da sua origem popular. Outro fator que aproxima os filmes chanchadescos do gosto do público, na visão da autora, é a utilização exacerbada da sátira, do deboche e da irreverência em textos clássicos reformulados para as chanchadas, em vez da sisudez e do respeito reclamados pelos eruditos. Para Dias, o grande sucesso das chanchadas é uma prova da circularidade das diversas formas de cultura evidenciada em cada cena filmada. As chanchadas significam "a união, mais do que fortuita, da sátira com o naturalismo hollywoodiano, somada às expressões da cultura popular brasileira” (1993, p. 20).

\footnotetext{
${ }^{13}$ A autora entende por "classes populares" o conjunto dos trabalhadores, operários, subalternos, populares, habitantes de periferias, favelas e subúrbios, migrantes e mobilizados em sindicatos, conforme aponta: SADER, Éder e PAOLI, Maria Célia. "Sobre 'classes populares' no pensamento
} 
Outro aspecto destacado por Dias na chanchada é a representação dos migrantes e da mulher nos enredos, a qual em nenhum momento apresenta-se como "ufanista" ou "irreal". Na ótica chanchadesca, os migrantes, depois de enfrentar alguns percalços, sempre acabam prosperando. A cidade representa o grande atrativo, o lugar onde o migrante tem a chance de "melhorar de vida", "viver com mais conforto", "ganhar mais". Por sua vez, as mulheres da chanchada têm uma participação bem mais marcada na vida pública, contrastando com a realidade da mulher brasileira, que se restringia nos anos 50 basicamente ao espaço doméstico, à vida de dona de casa. Ao contrário desse perfil, as mulheres chanchadescas são mais independentes, saem para o mundo, migram ou trabalham no meio artístico, conforme atesta a autora:

As chanchadas da década de 1950 sempre apresentavam em seus enredos mulheres que trabalhavam fora e freqüentavam o mesmo espaço público que os homens: hotéis, boates, estúdios de televisão, de cinema, e outros locais de trabalho. Entretanto, isso não parecia ser tão corriqueiro, pelo menos no que se refere à grande parte da população feminina" (1993, p. 86).

Apesar da extrema concisão, A chanchada no cinema brasileiro (1983), de Catani e Souza, é relevante pelo conteúdo de crítica social que os autores reconhecem nas chanchadas. Catani e Souza identificam diversos aspectos da realidade socio-política brasileira retratados nesses filmes, tais como a carestia, a falta d’água, os baixos salários, a inflação e a política desenvolvimentista, tanto no Rio de Janeiro, então capital federal, como em todo o país. Os encontros, desencontros e conflitos entre homem rural e urbano também são 
destacados pelos autores. Ressaltam, também, a consolidação da Atlântida, como maior produtora carioca e, conseqüentemente, brasileira, entre 1941 e 1947.

Catani e Souza (1983), assim como Bernardet (1979), assinalam que a chanchada, ao utilizar a paródia, apropria-se do modelo estrangeiro, valendose de um processo antropofágico para devolver ao público brasileiro uma paródia bem-humorada em um contexto que recria a idéia de identidade nacional. É por meio da paródia que a chanchada procura atrair o grande público, tentando capitalizar o sucesso do filme estrangeiro, incorporando gêneros norte-americanos de filmes, como os musicais, o policial, o western, a reconstrução de épocas. Paródias como Matar ou Correr (1954) e Nem Sansão nem Dalila (1954), entre outros, pautam-se nos originais realizados em Hollywood, só que são produzidos nos cenários de papelão de Jacarepaguá.

Entre os autores que trataram do tema chanchada, Sérgio Augusto pode ser considerado o cronista do gênero. A abordagem de Este mundo é um pandeiro: a chanchada de Getúlio a JK (1989), em estilo de crônica, enfatiza o caráter ideológico embutido nos filmes. A importância do livro para esta investigação reside no fato de o autor ser o único a questionar a função dos meios de comunicação na chanchada, mencionando a presença da mídia 
impressa, radiofônica e televisiva, apesar de não ter-se detido numa análise mais aprofundada sobre esses veículos nos filmes chanchadescos.

Segundo o autor, a chanchada teceu alguma espécie de crítica à imprensa, pois ao considerar as caracterizações "bizarras" como a de um fotógrafo de Massagista de madame (1959), que carrega um crachá com a palavra press na aba do chapéu, “[...] não seria lícito esperar que as chanchadas tivessem uma visão sem preconceitos do trabalho jornalístico" (1989, p. 169).

Sérgio Augusto constata que personagens repórteres foram encarnados por galãs como Anselmo Duarte (Carnaval em Marte, 1954) e Cyll Farney (O homem do Sputnik, 1959), mas, geralmente, apurar notícias era tarefa de personagens secundárias, tal como a colunista de fofocas do mundo artístico interpretada por Renata Fronzi em Vai que é Mole (1960).

Algumas personagens jornalistas, conforme observa o autor, conseguem chegar ao fim da história como heróis, a exemplo do repórter policial Fernando (Allan Lima) de O Camelô da Rua Larga (1958), em que abre caminho para a captura de uma quadrilha de falsários. Há chanchadas, entretanto, que tratam os jornalistas com o humor de crítica social típico do gênero, pois algumas personagens desse tipo, como aponta Sérgio Augusto, “[...] começavam e terminavam como bufões à cata de furos, como o Dondoca (Pagano Sobrinho) da 
chanchada paulistana Vou te Contá $[1958]^{14}$, enredado no rapto de uma criança em pleno carnaval carioca" (1989, p. 169).

Uma cena de Nem Sansão nem Dalila (1954) é avaliada por Sérgio Augusto como uma resposta da chanchada às críticas da imprensa:

[...] A primeira reação do personagem de Cyll Farney ao noticiário sobre a máquina do tempo do professor Incognitus [...] era de incredulidade: 'Coisas da imprensa', dizia ele, sem dúvida devolvendo na mesma moeda a má vontade com que as chanchadas costumavam ser tratadas nos jornais (1989, p. 169).

Contudo, a fala da personagem Hélio (Cyll Farney) é, precisamente, outra, e tem um sentido bem mais contundente em relação à imprensa: “Que nada! Isso é história para vender jornal”. A enunciação "Coisas da imprensa”, produzida por Sérgio Augusto (1989) como um discurso citado com base em cena de Nem Sansão nem Dalila (1954), apesar de descredenciar, no enunciado do autor supracitado, a veracidade da imprensa, tem um sentido mais genérico por não delimitar a ação. Já o enunciado verbal "Que nada. Isso é história para vender jornal”, que complementa seu sentido com a imagem de Hélio segurando o jornal e comentando a notícia com outra personagem em um salão de cabeleireiros, é enfático ao especificar que a imprensa produz histórias mirabolantes e forjadas a fim de incrementar a tiragem de jornais.

\footnotetext{
${ }^{14}$ Chanchada produzida pela companhia paulista Maristela.
} 
Ao avaliar o papel da mídia em De Vento em Popa (1957), Sérgio Augusto também comete um equívoco. O autor chama a atenção para a definição que a personagem Eloína (Eloína), uma empregada doméstica, dedica à “entrevista jornalística", para quem entrevista é "tudo aquilo que a gente diz e não sai publicado". Entretanto, as seqüências verbais a cargo da personagem Eloína significam justamente o inverso: “Entrevista é tudo aquilo que a gente não diz e sai publicado" $(1989,169)$.

De fato, faz mais sentido, pois a crítica refere-se à imprensa que distorce as palavras do entrevistado, moldando o discurso ao editar a entrevista, conforme a linha ideológica do veículo de comunicação. Quanto ao discurso da empregada doméstica ter algum efeito de crítica à imprensa, Sérgio Augusto (1989) pondera que "pode-se alegar que a personagem de Eloína, afinal, carecia de credibilidade", emendando com outro exemplo de personagem para afirmar que as chanchadas criticavam, sim, a imprensa: “[...] Não era uma pessoa de poucas luzes quem definia o jornal como uma casa de marimbondo ('quanto mais a gente mexe, mais leva ferroada') em Massagista de Madame (1959), e sim um profissional do ramo: o colunista disfarçado de massagista, interpretado por Zé Trindade" (1989, p. 169-170)

A nosso ver, mesmo sendo alegada a falta de credibilidade a Eloína - além de empregada doméstica a personagem anda às voltas com a bebida (para a elite cultural da época uma profissional cuja atividade está associada ao "fazer", e 
não ao "saber”, poderia ter uma opinião desse nível? Não soaria inverossímil?) —, é justamente esse fato, a inversão de papéis, que chama a atenção no filme: uma empregada doméstica, representante das classes populares, emitir uma opinião própria não apenas sobre a imprensa, mas explicar a uma (pseudo) assistente (Mara/Sonia Mamede) de um (pseudo) cientista (Oscarito), que se apropria do discurso da elite intelectual para alcançar seus objetivos, qual é o significado de uma entrevista.

Em De Vento em Popa (1957), tal como fica evidente nessa cena, a troca de identidade e a inversão dos papéis sociais são comuns (empregada doméstica com opinião própria sobre a imprensa; falsa assistente de um cientista; falso cientista, falso estudante de física atômica etc.), conforme a "fórmula" da narrativa chanchadesca ${ }^{15}$.

A representação crítica ao colunismo social, aponta Sérgio Augusto, foi muito freqüente nas chanchadas, por essa razão, "em vista [...] do tratamento pouco cordial dispensado às atividades parasitárias do colunismo social, em alta nas chanchadas no período juscelinista, é possível afirmar que o jornalismo recebeu as bordoadas nas saliências certas" (1989, p. 170).

O autor observa que a representação da alta burguesia, figura sempre presente nas chanchadas, abria caminho para personagens colunistas sociais:

\footnotetext{
${ }^{15}$ A respeito da narrativa chanchadesca ver o tópico 2.3. A narrativa chanchadesca: dos temas rurais ao cotidiano urbano.
} 
“Eles mudavam apenas de nome ou apelido: Dagô (Samba em Brasília) ${ }^{16}$, Gustavo (Com a Mão na Massa $)^{17}$, Charles de Troá (O Batedor de Carteiras $)^{18}$."

Sérgio Augusto identifica como modelo o "indefectível Ibrahim Sued, caricaturado até mesmo através de algumas das expressões que consagrou nos anos 50. Em Metido a Bacana [1957], um epígono de Ibrahim qualificava um príncipe recém-chegado ao Brasil de 'very khar'. A grã-fina interpretada por Renata Fronzi em É de Chuá [1958] chamava-se Maria Xangai. No pitoresco jargão suedês, 'khar' identificava coisas boas e 'xangai', coisas ruins”.

Para o autor, o colunista social de O homem do Sputnik (1959), Jacinto Pouchard (trocadilho e amálgama de Jacinto de Thormes com Jean Pouchard, interpretado por Cyll Farney), foi o único de seu tipo colocado acima do bem e do mal. "Talvez por ser interpretado pelo galã do filme (Cyll Farney), fugia ao estereótipo pejorativo, criando outro estereótipo: o do colunista social de má consciência, impaciente com as frivolidades da grã-finada e extremamente atencioso com os mais humildes companheiros de redação” (1989, p. 170).

Outra cena de O homem do Sputnik (1959) é analisada por Sérgio Augusto, a do repórter Alberto (Alberto Peres) saindo às pressas para cobrir o desfecho da queda do Sputnik no Brasil e dizendo “Acorda, Brasil!”, a um fotógrafo que dormia em um canto da redação. Para o autor, a ironia não se limitava ao país, mas à imprensa, “indiretamente gozada por dormir no ponto na hora de retratar

\footnotetext{
${ }^{16}$ Companhia Cinedistri, 1960 (nota nossa).

17 Distribuidora Franco-Brasileira, 1958 (nota nossa).
} 
com empenho e fidelidade o país que o espectador deixara do lado de fora do cinema". A imprensa da chanchada focalizava o Brasil "com desmensurado interesse, pouco importando a real expressão das ocorrências beneficiadas com uma manchete de primeira página” e os personagens repórteres inspiravam-se, vez por outra, em matrizes importadas (1989, p. 170).

Quanto ao rádio Sérgio Augusto assinala que, em alguns filmes, as personagens ouviam música pelo rádio e, ocasionalmente, uma notícia exclusivamente importante. Um exemplo é a chanchada Carnaval no Fogo (1949), na qual o rádio tem a dupla função de divertir e informar logo nas três primeiras seqüências:

\begin{abstract}
Na primeira tomada do filme, um cartaz anunciava um concerto no Teatro Municipal do Rio. Na segunda tomada, Oscarito aparecia regendo o tema anunciado no cartaz. Só quando a câmera se distanciava do comediante é que percebíamos que ele fingia reger o concerto, transmitido pelo rádio. Em seguida, Oscarito tirava o fraque, assumindo a sua verdadeira identidade: era faxineiro do hotel Copacabana Palace. Duas ou três cenas depois, ele e um companheiro de faxina (Modesto de Souza) dançavam o Minueto de Boccherini quando um boletim de última hora interrompia a música para informar que uma joalharia havia sido assaltada no centro da cidade. Nesse ponto, a câmera avançava até o aparelho de rádio e, quando se afastava, a ação já fora transferida para o esconderijo dos assaltantes (1989, p. 168).
\end{abstract}

O autor observa que bem modesto foi o papel da televisão nas chanchadas, geralmente apresentada como veículo exclusivo de shows e gincanas. Os jornais, por sua vez, pouco apareciam nos filmes, se considerada a freqüência com que jornalistas e referências à imprensa circulavam nas chanchadas.

\footnotetext{
${ }^{18}$ Distribuidora Nova América, 1958 (nota nossa).
} 
Conforme avaliamos nos filmes que constituem o corpus desta pesquisa, ao contrário do que afirma Sérgio Augusto (1989), não é nada tímida a presença da televisão nos enredos chanchadescos, alguns deles também criados nos anos 40 e início dos $60^{19}$. Na década de 50, a televisão é retratada de forma irônica ou paródica em chanchadas como Nem Sansão nem Dalila ${ }^{20}$ (discurso irônico, ao descrever a televisão como "a maravilha do século", a invenção do futuro), Absolutamente certo ${ }^{21}$ (discurso parodístico sobre um programa de TV) e Com água na boca ${ }^{22}$ (discurso irônico sobre os patrocinadores dos programas de TV).

Em Cinema brasileiro, propostas para uma história, Jean-Claude Bernardet observa a chanchada como uma produção a qual coube a função básica de levar o espectador a rir de si mesmo:

Os espectadores se projetariam sobre os personagens grotescos destes filmes e ririam deles, possibilitando uma catarse que aliviaria o complexo de inferioridade de um público/povo que se despreza quando se compara aos países industrializados, que não se sente suficientemente ativo no processo histórico de seu país, e, ao mesmo tempo, consolidaria o complexo de inferioridade (1979, p. 82).

O autor considera os filmes chanchadescos "comédias esculachadas" nas quais "o povo se despreza ante uma comparação com os países desenvolvidos". Mas reconhece o conteúdo de crítica social em algumas chanchadas, como em Nem Sansão nem Dalila (1954), “um dos melhores filmes políticos brasileiros”, no

${ }^{19}$ Carnaval no fogo (1949/Atlântida/Rio de Janeiro); Vai que é mole (1960/Herbert Richers/Rio de Janeiro); Marido de mulher boa (1960/Herbert Richers/Rio de Janeiro); O dono da bola (1961/Herbert Richers/Rio de Janeiro); Virou bagunça (1961/Watson Macedo-Cinedistri/Rio de Janeiro); Três colegas de batina (1961/Watson Macedo-Cinedistri/Rio de Janeiro).

${ }^{20}$ Realizada em 1954.

${ }^{21}$ Produzida em 1957. 
qual a personagem Sansão (Oscarito) comete uma sucessão de golpes políticos, numa paródia a Getúlio Vargas. São os problemas intrinsecamente ligados à vida cotidiana brasileira que realmente alimentam as piadas, as situações nas chanchadas.

A chanchada, na ótica de Bernardet, foi o único gênero cinematográfico realmente comercializado no mercado interno, pois esses filmes "davam dinheiro". E o recurso utilizado por essas películas como fórmula de sucesso é a paródia, um fenômeno usual no cinema popularesco brasileiro: "Alguns momentos tornaram-se antológicos, como a paródia [...] de Romeu e Julieta ${ }^{23}$ feita por Oscarito e Grande Otelo. Essa paródia inclui-se entre as inúmeras caricaturas, encontradas nesses filmes, da cultura culta e das elites intelectuais" (1979, p. 80).

Para o autor, a paródia trata-se de uma "avacalhação, um esculacho do modelo: ela degrada, macula o modelo opressor". Mas, para que a degradação funcione, é necessário que o modelo permaneça modelo. "Num jogo contraditório, ela ao mesmo tempo confirma o modelo enquanto tal e o degrada. A paródia é inclusive a confissão de que, no momento, não se consegue substituir o modelo por outro" (1979, p. 81). Entre as paródias dirigidas aos sistemas de dominação cultural, o autor destaca as pautadas nos filmes norte-americanos, diferenciando os momentos de imitação e de paródia na chanchada:

\footnotetext{
${ }^{22}$ Realizada em 1956.

${ }^{23}$ Cena do filme Carnaval no fogo, produzido pela Atlântida (1949) [nota nossa].
} 
A cenografia e coreografia dos números musicais provém muito de uma estética norte-americana. Aí não se trata de paródia, mas sim de imitação. Mas há momentos em que a chanchada não imita, mas parodia o modelo americano, e há dois casos em que a atitude paródica foi a própria inspiração dos filmes: Nem Sansão nem Dalila (1954) e Matar ou correr (1954), ambos de Carlos Manga, paródias de filmes americanos pouco antes lançados no Brasil, respectivamente Sansão e Dalila de Cecil B. de Mille” (1979, p. 80)

Bernardet pondera que, apesar de os momentos paródicos serem freqüentes em inúmeras chanchadas, a paródia sistematicamente elaborada como princípio de um filme inteiro é rara e encontra-se principalmente nos filmes de Carlos Manga. A forma mais comum nas chanchadas, segundo o autor, é o pastiche $e^{24}$.

No texto "A chanchada e o cinema carioca (1930-1955)", de cunho histórico, Vieira aponta a paródia como um traço característico das chanchadas. Essas produções parodiam a cultura estrangeira, especialmente o cinema dominante, pois há “uma preocupação em expor algumas feridas da vida política e social do país" (1987, p. 158). O autor pontua que as chanchadas de Carlos Manga, especialmente as musicais, demonstram mais fascínio pelo universo de Hollywood. A paródia, inserida no universo da tradição carnavalesca e da sátira, surge como uma resposta possível do cinema subdesenvolvido que, ao procurar imitar um cinema dominante, ri de si próprio.

Em "From high moon to jaws: Carnival and parody in brazilian cinema" (1995), Vieira aprofunda o tema sobre a utilização da paródia não apenas pela

\footnotetext{
${ }^{24}$ Espécie de imitação criativa de um texto.
} 
chanchada, mas também por outros gêneros cinematográficos, assinalando que a manifestação paródica assume diversas formas no cinema brasileiro, tais como a imitação de personagens da cultura pop (Oscarito em De Vento em Popa como "Melvis Prestes" é uma paródia a Elvis Presley) ou de figuras históricas, geralmente identificadas com determinada elite cultural (Oscarito travestido de “Helena de Tróia” em Carnaval Atlântida), ou segue aproximadamente a estrutura narrativa do filme original (caso de Nem Sansão nem Dalila).

Para o autor, Nem Sansão nem Dalila (1954), de Carlos Manga, usa o que talvez seja a mais perfeita metáfora de uma paródia no cinema brasileiro: enquanto no original Sansão e Dalila (1951), de Cecil B. de Mille, a força reside no cabelo da personagem Sansão/Victor Mature, no filme brasileiro a força materializa-se na peruca usada por Sansão/Oscarito. Em outros termos, o filme brasileiro está para a superprodução hollywoodiana assim como a peruca de oscarito está para o cabelo natural do ator americano. "Comparando as duas situações, vemos que a força do cabelo real, artificializado em um acessório (a peruca), é a metáfora da força de um sistema desenvolvido de uma economia poderosa, em oposição à força simulada de um cinema que imita” (1995, p. 257).

O relatório de pesquisa Cinema popular brasileiro e a representação da malandragem: de Oscarito a Mario Fofoca, a chanchada e a telenovela humorística (1998), trata da representação da malandragem no cinema popular brasileiro por meio de estudo comparativo entre chanchadas dos anos 50 e outras 
produções posteriores, dos anos 60,70 e 80 . 0 objetivo original, como descreve Catani, era realizar um estudo comparativo entre dois gêneros cômicos em meios de comunicação de massa: a chanchada (cinema) e a telenovela humorística (televisão). Mas o projeto foi reformulado, excluindo da análise a telenovela humorística, em razão da impossibilidade de acesso a essas produções, especificamente as da Rede Globo de Televisão, e da escassez financeira de realizar o trabalho de campo no Rio de Janeiro.

Desse modo, o relatório pontua que a chanchada inicialmente personifica o malandro ingênuo, interpretado por grandes atores, como Grande Otelo. Com a evolução da narrativa do gênero, esse malandro é substituído por caracterizações mais realistas, em função das mudanças socioeconômicas da década de 50 , que exigiam a valorização do trabalho. Um traço relevante da tipologia da "personagem malandro" é a sua imagem visual, a vestimenta que adota, que representa "mais uma forma de distinção social e cultural. [...] um desejo de auto-afirmação e um propósito de ascender socialmente” (1998, p. 24-25). Tratase de um estudo mais descritivo-interpretativo do que propriamente analítico.

O livro Paródia e chanchada: imagens do Brasil na cultura de classes populares (2005), de Meirelles, busca traçar um panorama histórico da chanchada como portadora das manifestações da cultura das classes populares. De forma bastante genérica, o autor situa o filme chanchadesco como fonte histórica, em que a paródia torna-se uma linguagem particular através da qual as classes 
populares se expressam, "ao ridicularizar os atos, costumes e práticas dos dominantes”. Para tanto, o autor analisa as paródias Carnaval Atlântida (1952) e Nem Sansão nem Dalila (1954), situando a primeira no campo da luta pelo centro da cultura (cultura popular versus cultura erudita) e a segunda no âmbito do direito à política.

Em suma, esses autores contribuíram para a contra-estigmatização da chanchada, gênero prosaico cinematográfico de verve cômica-popular, que até os dias atuais ainda permanece estigmatizado pela imprensa e pelo imaginário coletivo como produção cultural prosaica, trivial, ingênua, não raramente confundida com a pornochanchada, gênero criado e desenvolvido nos anos 70, misturando elementos da chanchada com erotismo ${ }^{25}$.

\subsection{QUADRO TEÓRICO DE REFERÊNCIA}

Esta pesquisa privilegia uma abordagem teórica do discurso como fenômeno da dialogia, tal como postula o estudioso da linguagem Mikhail Bakhtin. Referenciada no princípio dialógico desse autor, a investigação desenvolve-se apoiada nos conceitos da Análise do Discurso de linha francesa (AD) e da narrativa cinematográfica. Com esta referência conceitual, buscamos examinar as vozes que se entrecruzam e se fazem presentes nas marcas enunciativas do discurso narrativo do gênero cinematográfico chanchada. 
Em princípio, apresentaremos os fundamentos da $A D$ aos quais nos filiamos nesta pesquisa e a relação que estes estabelecem com as reflexões de Bakhtin a respeito do dialogismo. Em seguida, exploraremos a concepção bakhtiniana de discurso dialógico e proposições referentes à narrativa cinematográfica, aproximando-se do nosso objeto, para o qual empregaremos as categorias de análise construídas com base neste instrumental teórico.

\subsubsection{CONCEITOS-CHAVE DA AD PARA A PESQUISA}

As teorias que abarcam a AD, desenvolvidas na França a partir dos anos 60, originam-se de um quadro epistemológico que engloba quatro áreas do conhecimento: a lingüística, o materialismo histórico, a teoria do discurso e a psicanálise, esta última relacionada com a questão do sujeito. Atuando nesse campo interdisciplinar, a $A D$ considera o funcionamento lingüístico e textual como parte de um contexto socio-histórico de produção, articulando o interior com o exterior do enunciado, o plano lingüístico com o plano social (o lugar de investimentos sociais, históricos, psíquicos).

Nessa perspectiva, a linguagem é um fenômeno estudado não apenas em relação ao seu sistema interno, mas também em relação ao diálogo e ao discurso como espaço da heterogeneidade, de interação intersubjetiva e interdiscursiva,

\footnotetext{
${ }^{25}$ A respeito do estigma negativo atribuído à chanchada ver tópico 3.1. A mídia impressa:
} 
de negociação, de confronto, de polêmica entre o um e o outro, sendo a questão da alteridade central para AD.

Em linhas gerais, os conceitos que norteiam a AD deslocaram-se de uma concepção homogeneizadora da língua e do sujeito para uma concepção heterogênea do discurso e do sujeito. Tais reformulações teóricas, demarcadas como AD-1, AD-2 e AD-3, são atribuídas principalmente a Pêcheux.

$\mathrm{Na}$ AD-1, Pêcheux baseia-se nos postulados de ideologia de Louis Althusser $^{26}$ e de discurso de Michel Foucault ${ }^{27}$ para desenvolver os conceitos de formação ideológica e formação discursiva, articulando-os ao reformular as proposições foucaultianas de formação discursiva. Nessa acepção, o discurso é concebido como uma das instâncias em que a materialidade ideológica se concretiza. Assim, qualquer formação ideológica ${ }^{28}$ tem como um de seus

\footnotetext{
jornais e revistas que estigmatizaram a chanchada.

${ }^{26}$ Althusser, ao realizar uma releitura de Marx, no ensaio Ideologia e aparelhos ideológicos do Estado (1970), elabora uma teoria da ideologia, distinguindo-a da ciência e desmembrando-a em duas teorias: "teoria da ideologia em geral" e "teoria das ideologias particulares", cujo objeto seria o estudo da deformação entre o real vivido e a representação que se faz desse real, sendo a linguagem o lugar privilegiado em que a ideologia se materializa. A partir das ideologias particulares, que exprimem posições de classe, o autor estabelece uma diferenciação entre ARE (aparelhos repressores do Estado) e AIE (aparelhos ideológicos do Estado): enquanto os primeiros "funcionam de uma maneira massivamente prevalente pela repressão (inclusive física), embora funcione secundariamente pela ideologia", os segundos "funcionam de um modo massivamente prevalente pela ideologia, embora funcionando secundariamente pela repressão [...]" (Althusser, 1974, p. 47). Na concepção de ideologia em geral, a ideologia é entendida como a abstração dos elementos comuns a qualquer ideologia concreta.

27 Foucault influencia a constituição da AD, ao publicar, em 1969, Arqueologia do saber, voltando-se para a análise de diferentes práticas discursivas como dispositivo enunciativo e institucional. 0 autor define o discurso como um conjunto de enunciados que "têm seus princípios de regularidade em uma mesma formação discursiva".

${ }^{28}$ Constituem-se por um conjunto complexo de atitudes e representações que não são nem individuais, nem universais, mas que dizem respeito às posições de classe em conflito umas com as outras. Cada formação ideológica pode compreender várias formações discursivas interligadas (Brandão, 2004).
} 
componentes uma ou várias formações discursivas interligadas. São as formações discursivas que, numa formação ideológica específica e levando em conta uma relação de classe, determinam “o que pode e deve ser dito" a partir de uma posição e conjuntura dadas, ou seja, a partir das condições de produção ${ }^{29}$. A noção de sujeito, por seu turno, é determinada pela posição do lugar de onde se fala, isto é, do interior de uma formação discursiva, regulada por uma formação ideológica.

Na AD-2, a formação discursiva passa a ser concebida como um espaço estrutural que se relaciona com seu exterior ao ser "invadida" por outras formações discursivas que nela se repetem, sob a forma de pré-construídos ${ }^{30}$ e de discursos transversos, fornecendo-lhes evidências discursivas fundamentais (Pêcheux, 1990). Nesse sentido, a noção de formação discursiva torna-se inseparável da concepção de interdiscurso, que surge para denominar o exterior específico que irrompe no interior de uma formação discursiva. O conceito de formação discursiva como dispositivo estrutural fechado ainda é mantido, mas, por outro lado, esse fechamento é fundamentalmente instável por ser o resultado paradoxal da irrupção de um “exterior”, levando Pêcheux a reconhecer o discurso como objeto heterogêneo.

29 As condições de produção, para Pêcheux, são definidas pelos lugares ocupados pelos interlocutores na estrutura de uma formação social. Desse modo, as CPs dizem respeito à instância na qual o discurso é produzido: o contexto histórico-social, os interlocutores, o lugar de onde falam e a imagem que fazem de si, do outro e do referente. A noção de condições de produção substituiu a noção vaga de "circunstâncias" nas quais um discurso é produzido, para explicitar que se trata de estudar nesse contexto o que condiciona o discurso (Brandão, 2004; Charaudeau e Maingueneau, 2004). 
$\mathrm{Na}$ perspectiva do primado do interdiscurso sobre o discurso, tal como postula Maingueneau (1989), toda formação discursiva constitui seu domínio de saber articulando um conjunto de formulações aceitáveis, ao determinar "o que pode e deve ser dito", e excluindo formulações inaceitáveis a esse domínio, ao estabelecer "o que não pode e não deve ser dito". Esse domínio do saber próprio à formação discursiva constitui-se numa dinâmica, ao mesmo tempo, de delimitação e de deslocamento do seu interior.

O fechamento de uma formação discursiva, portanto, não caracteriza um corpus discursivo homogêneo, mas a tentativa do enunciador de dar coerência e uniformidade ao conjunto, de eliminar as contradições próprias de todo discurso resultantes dos embates que se travam numa zona fronteiriça na qual se inscrevem diversas formações discursivas. “O próprio de toda formação discursiva é dissimular, na transparência do sentido que nela se forma, a objetividade material contraditória do interdiscurso, que determina essa formação discursiva como tal” (Pêcheux, 1988, p. 162).

Nesse sentido, na AD-3, há um deslocamento teórico da noção de "máquina discursiva estrutural" para "máquinas discursivas paradoxais". 0 sujeito do discurso, concebido inicialmente como puro efeito de assujeitamento decorrente da identificação com determinada formação discursiva, passa a ser

\footnotetext{
30 Noção introduzida por Paul Henry, que diz respeito aos elementos produzidos em outros discursos, anteriores ao discurso em estudo e independentemente dele. Cabe frisar que todo
} 
influenciado por outros discursos originários de outras formações discursivas. A noção de sujeito é definida, nesse caso, pela relação dinâmica entre identidade e alteridade, relação que se situa no espaço discursivo criado entre interlocutores, que é o texto. Nessa ótica, a formação discursiva apresenta-se não mais como a expressão estabilizada da "visão de mundo" de um grupo social, mas como domínio no qual a relação com o outro deve ser percebida independentemente de qualquer forma de alteridade marcada.

Em outras palavras, os enunciados apresentam uma dupla face: um “direito” e um “avesso” que são indissociáveis. Nesse prisma, a identidade de uma formação discursiva não deve ser buscada numa análise fechada, voltada exclusivamente para seu interior, mas evidenciada numa análise que privilegie o diálogo da formação discursiva com outras formações discursivas que atravessam o seu campo.

Para Maingueneau, uma formação discursiva não deve ser concebida como um bloco compacto que se opõe a outros, mas como uma realidade “heterogênea por si mesma". Relacionando tal assertiva com o objeto desta pesquisa (o discurso da chanchada), não poderíamos colocar a formação discursiva do filme chanchadesco em oposição à formação discursiva do filme melodramático ou sócio-histórico, mas como uma formação discursiva que no embate dialógico assimila elementos de outros discursos, pois o interdiscurso 
consiste em um processo de reconfiguração incessante ${ }^{31}$ no qual uma formação discursiva é levada [...] a incorporar elementos préconstruídos, produzidos fora dela, com eles provocando sua redefinição e redirecionamento, suscitanto, igualmente, o chamamento de seus próprios elementos para organizar sua repetição, mas também provocando, eventualmente, o apagamento, o esquecimento ou mesmo a denegação de determinados elementos (Maingueneau, 1976, p. 24).

Entretanto, a AD, ao levar em conta as condições de uso da linguagem, busca apreender a singularidade desse uso, distinguindo um discurso de outro, e, por outro lado, procura construir uma generalidade, inserindo esse uso particular, esse discurso, em um domínio comum. Esse procedimento a princípio contraditório, como assinala Orlandi, é decorrente da necessidade metodológica de estabelecer tipologias de discurso que teriam, para a $A D$, a mesma função classificatória que têm as categorias na análise lingüística. Trata-se de “[...] um princípio organizador, do primeiro passo para a possibilidade de se generalizarem certas características, se agruparem certas propriedades e distinguirem classes” (Orlandi, 2002, p. 217).

A questão da tipologia, na $A D$, tem várias definições formuladas por autores como Benveniste, Dubois, Guespin, Mandarin, Maingueneau, entre outros. A que nos interessa é a noção adotada por Maingueneau. O autor nos lembra que a $A D$ tem por especificidade procurar construir modelos de discurso articulando esses modelos sobre condições de produção: “[..] a AD não pode

\footnotetext{
${ }^{31}$ Grifo do autor.
} 
deixar de refletir sobre o gênero quando aborda um corpus ${ }^{32}$. Um enunciado ‘livre’ de qualquer coerção é utópico” (1989, p. 38).

Em outros termos, os enunciados apresentam-se não apenas como fragmentos de língua próprios desta ou daquela formação discursiva, mas também como amostras de um certo gênero de discurso. Há, para Maingueneau, dois tipos extremos de discurso: discursos muito complexos, para os quais a relação com as condições de produção seria tênue (a exemplo do discurso teológico), e discursos muito difusos, em que a relação com as condições de produção seria mais imediata (a exemplo do discurso ordinário cotidiano ou conversa). Como ponto de equilíbrio, o autor aponta uma articulação mais estreita entre o discurso político e as condições de produção. Nessa ótica, todo gênero é produto histórico, a materialização de um fenômeno dinâmico que é o processo discursivo, e por essa razão não é possível desvincular o estudo do tipo da sua relação com o funcionamento discursivo.

“Em termos de constituição formal, o que determinará o tipo de discurso é o modo como esse traço aparece em um discurso, em relação às suas condições de produção" (Orlandi, 2002, p. 235). Desse modo, cabe reiterarmos que não há tipos puros de discurso; determinadas características que costumamos atribuir a um dado discurso se fazem presentes também em outros.

${ }^{32}$ Grifo nosso. 
Nesta investigação, delimitamos o amplo espaço discursivo ${ }^{33}$ da chanchada como um gênero prosaico, com base nos postulados de Bakhtin sobre gêneros do discurso. Esse recorte foi estabelecido com base na percepção de que o discurso chanchadesco tem como "matéria-prima” o universo das enunciações cotidianas. No gênero prosaico chanchadesco, identificamos elementos característicos, porém não exclusivos, dessa formação discursiva, a exemplo da carnavalização e de formas estilísticas como a paródia, a ironia e a caricatura presentes em sua narrativa, princípios nos quais o marginalizado e o excluído tornam-se o centro do enunciado. Nessa perspectiva, observamos a chanchada como um espaço interdiscursivo atravessado por diversas formações discursas, como o discurso político, o discurso médico, o discurso intelectual, o discurso midiático, enfim, toda sorte de diálogos cotidianos e de enunciações provenientes de diversos segmentos sociais (instituições públicas e privadas) que circulavam no contexto socio-histórico da década de 50.

Em consonância com Orlandi (2002), entendemos que a escolha de um gênero discursivo não se faz em “abstrato", mas decorre da concepção de discurso do analista, do modelo de análise que utiliza. Para Maingueneau (1989), cabe ao analista definir, em função de seus objetivos, os recortes genéricos que lhe parecem pertinentes. Mas a interpretação de qualquer tipologia não deve ser

\footnotetext{
${ }^{33}$ Segundo Maingueneau (1989, p. 116-117), universo discursivo “é o conjunto de formações discursivas, de todos os tipos que coexistem, ou melhor, interagem em uma conjuntura. Esse conjunto é finito, mas inapresentável [...] corresponde [...] ao que J.R. Maradin reformulando um termo de Foucault chamava de arquivo". Campo discursivo, na acepção do autor, é "[...] um conjunto de formações discursivas [...] que se delimitam por uma posição enunciativa em dada região", a exemplo do campo discursivo religioso, literário, jornalístico, entre outros.
} 
feita de forma automática; os resultados devem ser associados ao contexto sóciohistórico do texto-objeto de análise.

A noção de formação discursiva como campo da interdiscursividade e da heterogeneidade (AD-3) que the são constitutivas não exclui a relação fundamental entre discurso e ideologia. Neste estudo, entendemos ideologia como uma visão, uma concepção de mundo de um determinado segmento social numa dada conjuntura sócio-histórica. Essa perspectiva nos leva a compreender os fenômenos lingüísticos e ideológicos como noções estreitamente ligadas numa relação em que a linguagem é uma das instâncias em que a ideologia materializase. Nesse sentido, aproximamo-nos dos postulados de Bakhtin sobre a linguagem, para quem não há palavra neutra e, por conseguinte, todos os discursos são ideológicos. Essa concepção de ideologia como algo próprio ao signo não elimina, necessariamente, a noção marxista de ideologia como escamoteamento e dissimulação da realidade, se entendermos ideologia como uma forma legítima de pensar o mundo.

Tal como pontua Brandão, o recorte do mundo pela visão de um determinado segmento social, atravessado pela subjetividade, embora se apresente como verdadeiro, pode ser incompatível com os modos de organização da realidade. Nesse sentido, a ideologia pode ser vivida de forma inconsciente ou ser produzida intencionalmente. "Isso pode ocorrer em determinados discursos 
como o político, o religioso, o da propaganda, enfim, os marcadamente institucionalizados” (2004, p. 31). Esses discursos recortam a realidade, mas o real, por um mecanismo de manipulação, não se mostra como tal, uma vez que, intencionalmente, omitem-se, atenuam-se ou falseiam-se dados, tais como as contradições subjacentes nas relações sociais. Essa maneira de ver o mundo é o recorte que uma determinada instituição ou segmento social em um dado sistema faz da realidade, retratando, ainda que de forma enviesada, uma visão de mundo. Partimos do pressuposto de que essa noção geral de ideologia aplica-se ao discurso narrativo da chanchada, uma vez que este abriga uma ideologia ambígua, uma visão de mundo da ideologia populista dominante em sua época e, ao mesmo tempo, uma concepção de mundo das classes subalternas.

No quadro desta pesquisa, vale destacar ainda a distinção apontada por Foucault (1969) entre enunciado e enunciação. Para o autor, enquanto a enunciação é um acontecimento que não se repete e define-se como uma particularidade situada e datada, o enunciado define-se por sua repetibilidade. Nesse sentido, o conceito de enunciado, para a $A D$, é tido como o produto de um processo e a enunciação é o processo que o produz e nele deixa marcas da subjetividade, da intersubjetividade, da alteridade que caracterizam a linguagem em uso.

A dimensão sociointeracionista da linguagem, concebida por M. Bakhtin, é assimilada pelo quadro teórico da $A D$, que reconhece o ato de enunciação como 
uma forma de interação social, na qual o outro (a figura do destinatário a quem está voltada toda alocução) desempenha um papel essencial na constituição do significado. É na relação dinâmica com a alteridade que o sujeito, sociohistoricamente e ideologicamente situado, constitui a interação com o outro, assumindo diferentes posições enunciativas e ideológicas, quer com elas se aliando, quer com elas se confrontando. Como sujeito histórico, processa-se nele uma memória discursiva, pois a toda formação discursiva, como assinala Maingueneau, é associada uma memória discursiva, “constituída de formulações que repetem, recusam e transformam outras formulações” (1989, p. 115). Para Pêcheux, “[...] a memória discursiva seria aquilo que, face a um texto, surge como acontecimento a ler, vem restabelecer os 'implícitos' (quer dizer, mais tecnicamente, os pré-construídos, elementos citados e relatados, discursos transversos etc.)" (1999, p. 52).

\subsubsection{A DIMENSÃO DIALÓGICA DO DISCURSO}

O dialogismo, conforme aponta Bakhtin, é um princípio que constitui a linguagem e dá sentido ao discurso, o qual jamais é individual, mas produto de interlocuções e do diálogo entre discursos. Em outros termos, o discurso relaciona-se intrinsecamente com outros discursos numa rede múltipla de vozes que se entrecruzam. Nas palavras do autor:

A orientação dialógica é naturalmente um fenômeno próprio a todo o discurso. [...] Em todos os seus caminhos até o objeto, em todas as direções, o discurso se encontra com o discurso de outrem e não pode deixar de participar, com ele, de uma interação viva e tensa (Bakhtin, 1993a, p. 88). 
Existem duas grandes noções de dialogismo que compõem os estudos de Bakhtin, cada qual com um papel definido: uma que trata do diálogo entre interlocutores e outra que se refere ao diálogo entre discursos.

A primeira delas, também denominada de diálogo interacional, abarca quatro aspectos centrais: 1) interação entre interlocutores, que é o princípio fundador da linguagem ${ }^{34}$; 2) sentido do enunciado, que depende da relação entre sujeitos, ou seja, o sentido constrói-se na produção e na interpretação dos enunciados; 3) intersubjetividade, que é anterior à subjetividade, uma vez que a relação entre interlocutores não apenas funda a linguagem e dá sentido ao enunciado, mas constrói os próprios sujeitos produtores do enunciado; 4) interação social, que se manifesta na relação entre sujeitos (entre os interlocutores que interagem) e dos sujeitos com a sociedade (Barros, 1997).

A segunda acepção de dialogismo, a de diálogo entre discursos ou interdiscursividade, diz respeito à materialização da dialogia no discurso, ou seja, às relações que mantêm com outros discursos. De acordo com essa noção, todo discurso é dialógico por natureza, pois se constrói na interação com a fala alheia, no diálogo entre vozes que se completam, respondem umas às outras ou polemizam entre si, a partir de pontos de vista diferentes, no contexto verbal e não-verbal. Assim concebido, o discurso apenas se torna produtor de sentido na interação com outros discursos. 
Nesta pesquisa, nos situamos nesse plano de discursividade - do diálogo entre vozes -, buscando examinar o efeito polifônico criado pelo discurso da narrativa chanchadesca sobre a mídia. Esse efeito de sentido, estreitamente associado ao princípio dialógico, foi minuciosamente examinado por Bakhtin na obra de Dostoiévski, na qual o autor identificou a criação de um gênero romanesco essencialmente novo, o romance polifônico, cuja orientação da narração (ou enunciação), independentemente de quem a conduza, é permeada pela multiplicidade de vozes que deixam suas marcas em um mesmo enunciado. Nesse sentido, todo enunciado, determinado socialmente e historicamente, é potencialmente uma arena de lutas em que vozes, situadas em diferentes posições, geram maior ou menor efeito polifônico, numa relação de aliança, oposição ou polêmica. No efeito polifônico, o discurso é atravessado por outros discursos com os quais dialoga.

Ao considerar a linguagem um fenômeno sociointeracionista, Bakhtin assinala que não há palavra (linguagem) neutra, pois ela está sempre carregada de um conteúdo ou de um sentido ideológico ou vivencial. A palavra é o signo ideológico por excelência, caracterizando-se pela plurivalência, uma vez que é produto da interação social e retrata as diferentes formas de significar a realidade, conforme diferentes posicionamentos das vozes que circulam socialmente. Para o autor,

\footnotetext{
${ }^{34}$ Bakhtin amplia a noção dos lingüistas saussurianos, ao considerar não apenas a linguagem essencial para a comunicação, mas também a relação dialógica entre sujeitos.
} 
[...] a língua não conserva mais formas e palavras neutras que 'não pertencem a ninguém' [...] Todas as palavras evocam uma profissão, um gênero, uma tendência, um partido, uma obra determinada, uma pessoa definida, uma geração, uma idade, um dia, uma hora. Cada palavra evoca um contexto ou contextos, nos quais ela viveu sua vida socialmente tensa; todas as palavras e formas são povoadas de intenções (Bakhtin, 1993a, p. 100).

Nesse prisma, o discurso jamais é individual, pois se constrói no plano social, no horizonte ideológico, entre pelo menos dois interlocutores ou no diálogo entre discursos, ou seja, no relacionamento com outros discursos. De acordo com o teórico russo, o problema, numa análise dialógica, não consiste em saber apenas quais são os estilos de linguagem, mas identificar sob que ângulo dialógico esses estilos se confrontam ou se opõem.

O dialogismo postulado por Bakhtin é constituído pelo dito (contexto verbal) e pelo não-dito (contexto não-verbal). O dito é apenas um dos elementos da enunciação, na qual também opera o não-dito, que nada mais é do que uma enunciação formada a partir de uma outra focalização. O seguinte excerto de $M$. Holquist (1990, p. 61) esclarece esse aspecto do discurso dialógico: “[...] o discurso não reflete a situação, ele é a situação ${ }^{35 "}$.

Em outras palavras, a situação é parte integrante do enunciado, indispensável à sua constituição semântica. Para o discurso ser apreendido em sua totalidade é essencial que se considere o que está além do verbal. Assim, o sentido da palavra é totalmente determinado por seu contexto, e há tantas

${ }^{35}$ grifo nosso. 
significações possíveis quantos contextos possíveis (Bakhtin / V.N. Volochinov, 2004).

O autor assinala, ainda, que os contextos possíveis de uma única e mesma palavra são freqüentemente opostos. Exemplos clássicos dessa oposição podem ser encontrados nas réplicas de um diálogo, nas quais uma única e mesma palavra pode figurar em dois contextos mutuamente conflitantes. Assim, toda palavra comporta duas faces, pois ela é determinada tanto pelo fato de que procede de alguém, como pelo fato de que dirige-se a alguém, constituindo-se como o produto da interação do locutor e do ouvinte. No contexto global inerente à produção de sentido pelo discurso, o discurso vive fora de si mesmo, orientado para seu objeto. "Estudar o discurso em si mesmo, ignorar a sua orientação externa, é algo tão absurdo como estudar o sofrimento psíquico fora da realidade a que está dirigido e pela qual ele é determinado" (Bakhtin, 1993a, p. 99).

Mantendo a concepção bakhtiniana de dialogismo, tomamos o enunciado como um elemento constitutivo da dialogia, como uma produção discursiva que, surgida de maneira significativa em um determinado momento social e histórico, não pode deixar de tocar os diversos fios dialógicos tecidos pela consciência ideológica em torno de um dado objeto de enunciação, não pode deixar de ser participante ativo do diálogo social, emergindo desse diálogo como seu prolongamento, sua réplica. Nesse sentido, 
[...] o enfoque dialógico é possível a qualquer parte do enunciado, inclusive a uma palavra isolada, caso esta palavra não seja interpretada como uma palavra impessoal da língua, mas como signo da posição semântica de um outro, como representante do enunciado de um outro, ou seja, se ouvirmos a voz do outro. Por isso, as relações dialógicas podem penetrar no âmago do enunciado, inclusive no íntimo de uma palavra isolada se nela se chocam dialogicamente duas vozes (Bakhtin, 1997, p. 184).

Na relação dialógica a palavra está sempre orientada para um interlocutor concreto, situado no plano socio-histórico e no horizonte ideológico. Em Marxismo e filosofia da linguagem, Bakhtin assinala que a verdadeira essência da língua não é constituída por um sistema abstrato de formas lingüísticas nem pela enunciação monológica isolada, nem pelo ato psicofisiológico de sua produção, mas pelo fenômeno social da interação verbal. A natureza da enunciação é produto da interação social e as relações dialógicas manifestam-se em qualquer enunciado, sendo possíveis entre os estilos de linguagem, os dialetos sociais, desde que estes sejam entendidos como posições semânticas, que nestes ouçamos a voz do outro, os sentidos que se estabelecem nessa interação.

Dentro desse quadro enunciativo-discursivo, adotamos a definição de enunciado como o produto de um processo dialógico, resultado de uma enunciação, noção que converge com a natureza do enunciado assimilada pela $A D$ com base em Foucault. É nessa perspectiva que entendemos texto como enunciado. Dito de outra maneira, o diálogo materializa-se no discurso, que, por seu lado, concretiza-se no enunciado/texto. A enunciação é o processo de confecção do enunciado/texto. 
Uma vez que a interação dialógica dos discursos materializam-se em enunciados voltados para algum destinatário, o ponto-chave do dialogismo é entender um discurso dentro de outro discurso, isto é, buscar a interdiscursividade que se processa na enunciação e se concretiza no enunciado. Ao enunciar, o enunciador instaura um diálogo com o discurso do destinatário na medida em que o concebe como um elemento ativo, pois o discurso, constituindo-se na atmosfera do já-dito, é determinado ao mesmo tempo pela réplica ainda não-dita, mas solicitada e já prevista. Nas palavras de Bakhtin,

O discurso vivo e corrente está imediata e diretamente determinado pelo discurso-resposta futuro: ele é que provoca esta resposta, pressente-a e baseia-se nela. Ao se construir na atmosfera do 'jádito', o discurso é orientado ao mesmo tempo para o discursoresposta que ainda não foi dito, discurso, porém, que foi solicitado a surgir e que já era esperado. Assim é todo diálogo vivo (1993a, p. 89).

As vozes, por seu turno, compreendem diálogos, negociações que se processam na produção de um enunciado. Essas vozes precedem os enunciados, fazendo-se presentes neles no momento de sua produção (na enunciação), pois o produtor do discurso é sempre um respondente em maior ou menor grau.

Segundo Maingueneau, a orientação dialógica do discurso não se limita aos enunciados que trazem a figura do interlocutor, pois no espaço discursivo o outro não é “[...] nem um fragmento localizável, nem uma citação, nem uma entidade exterior, não é necessário que ele seja atestável por alguma ruptura visível da compacidade do discurso [...]” (1984, p. 31). 
Bakhtin nos lembra que cada esfera de atividade, cada campo de atuação social, ao produzir um enunciado, tem concepções diversas de destinatários (com diferentes faces, perfis, dimensões), fazendo aparecer e circular diferentes gêneros discursivos. No plano da mídia, entendemos que é por meio do jogo dialógico que ela assume um papel fundamental na construção e circulação de discursos no contexto socio-histórico.

Em suma, a perspectiva enunciativa-discursiva de Bakhtin reconhece as marcas enunciativas como discursivas. Tal concepção considera não apenas as marcas verbais deixadas no enunciado, mas os rastros da enunciação de um lugar histórico e social do sujeito, de uma posição discursiva que circula entre discursos e faz circular discursos, na vida, na arte e nas ciências.

\subsubsection{O DISCURSO DO CINEMA NARRATIVO}

As abordagens teóricas da narratologia são numerosas e variadas, pois seu estudo, relativamente novo no campo da literatura e, particularmente, no âmbito do cinema, tem sido alvo de controvérsias e discussões. Nesta pesquisa, não entraremos no debate relativo às várias acepções correntes da narrativa. Interessa-nos as principais convergências entre noções pertinentes com o modelo analítico-teórico que tentamos projetar. Para tanto, buscamos em Lefebve (1970), Bremond (1973), Genette (1972), Aumont e Marie (1988), Aumont et al. 
(1995), Vernet (1995), Vanoye e Goliot-Lété (1994); Metz (1972; 1973; 1991) e Eco $(1979 ; 1992)$ as similitudes a propósito do discurso narrativo, com o objetivo de procedermos uma análise do discurso fílmico chanchadesco em três níveis: verbal, visual e sonoro ${ }^{36}$.

Na esteira de Propp, que chamou a atenção para a existência de um plano de organização global da narrativa, muitos foram os teóricos que se debruçaram no prolongamento da análise estrutural da narrativa. Há duas principais vertentes dessas investigações: a primeira, eminentemente teórica, propõe-se a reconstituir uma "língua universal da narrativa” por meio da formulação de categorias e regras combinatórias. Essa corrente foi capitaneada, entre outros, pelos trabalhos de Roland Barthes, Bremond e Greimas. Para Barthes, que sintetiza esse objetivo, a análise da narrativa tem a função de reunir narrativas para extrair delas uma estrutura (Barthes, 1973).

A segunda vertente considera estrutura não como sinônimo de categorias e regras invariantes, mas denomina na organização específica de cada texto narrativo o conjunto de elementos funcionalmente necessários e textualmente pertinentes. Desse modo, numa análise que se pretende descritiva, há um certo consenso em relação aos subdomínios que devem ser levados em conta quando se examina a estrutura de uma narrativa concreta: no plano da história, levamse em conta as ações, as personagens e os espaços nas suas relações de interdependência, considerando o peso estrutural específico de cada um desses

\footnotetext{
${ }^{36}$ Os procedimentos de leitura do objeto estão descritos detalhadamente no tópico 1.4.2.
} 
elementos (ações decisivas para o desenrolar da trama, ações subsidiárias de natureza indicial, distinção entre personagens principais, secundárias etc.) (Reis e Lopes, 1994).

Entendemos que analisar um filme consiste em um exercício de interpretação crítica que, de certa maneira, implica “desconstruir” o objeto visando à “reconstrui-lo". Tal como pontua Eco (1992), a interpretação crítica não comporta uma conotação avaliativa que geralmente se emprega ao termo crítica, mas se interessa pelo sentido e pela produção de sentido. Em outros termos, busca averiguar hipóteses pertinentes com a obra como um todo.

Nesta investigação, alinhamo-nos à segunda vertente da análise "estrutural" da narrativa, mais flexível, uma vez que esta nos permite “construir" um modelo analítico-descritivo para examinarmos o discurso narrativo da chanchada, materializado no enunciado que se presentifica no espaço-tempo diegético. O que está em pauta é o estudo da narrativa enquanto discurso e não da narrativa enquanto história.

Mas como definimos, no quadro deste estudo, narrativa, ou melhor, o discurso que se materializa no texto narrativo? Tal como define Lefebve, convenhamos em chamar narrativa

a todo o discurso que nos dá a evocar um mundo concebido como real, material e espiritual, situado num espaço determinado, num tempo determinado, refletido a maioria das vezes num espírito 
determinado que, ao invés da poesia, pode ser o de uma ou de várias personagens tanto quanto o do narrador (1975, p. 170).

Esse mundo da narrativa suposto real só se torna acessível pelo discurso, pois ao invés da experiência cotidiana, nunca dele conheceremos senão o que o autor nos quer efetivamente dizer.

Para Bremond, todo ciclo narrativo consiste em um discurso que integra uma sucessão de acontecimentos de interesse humano na unidade de uma mesma ação. Isto quer dizer que onde não há sucessão não há narrativa, mas, por exemplo, descrição (se os objetos do discurso são associados por uma contigüidade espacial), dedução (se eles estão implicados) ou efusão lírica (se eles evocam uma metáfora ou metonímia):

Onde não há integração na unidade de uma ação, não há narrativa, mas somente cronologia, enunciação de uma sucessão de fatos não coordenados. Onde enfim não há implicação de interesse humano (onde os acontecimentos relacionados não são produzidos nem por agentes nem sofridos por pacientes antropomorfos) não pode haver narrativa, porque é somente por relação com um projeto humano que os acontecimentos tomam significação e se organizam em uma série temporal estruturada (1973, p. 114).

O cinema, genuinamente um meio de registro, pôde tornar-se narrativo, entre outras razões ${ }^{37}$, porque originalmente a sua representação se dá através da imagem figurativa em movimento, matéria própria à expressão cinematográfica. A imagem do cinema, por não ser única, não ser fixa (o fotograma sobre a

\footnotetext{
${ }^{37} 0$ encontro do cinema e da narração também foi possível em razão da busca de legitimidade da expressão cinematográfica como arte, o que implicou, num primeiro momento, a "apropriação", pelo cinema, de elementos narrativos da literatura, especialmente do romance.
} 
película é captado no meio de outros inúmeros fotogramas) e tampouco independente do tempo, ofereceu à ficção a duração (o tempo) e a transformação (o espaço diegético ou extra-diegético que se transforma na sua relação com o tempo) ${ }^{38}$ (Aumont et al.; Vernet, 1995).

Essa especificidade do movimento na imagem cinematográfica coadunouse com a estrutura de qualquer ficção, que consiste, segundo a concepção estruturalista de Bremond $(1973)^{39}$, no encaminhamento de um estado inicial a um estado final, podendo ser esquematizada por uma série de transformações que se encadeiam através de sucessões de ações, umas geradoras das outras, em um mecanismo de causa e efeito: virtualidade (missão a cumprir) - atualização (realização da missão) - acabamento (missão cumprida). Ou, por outro lado: virtualidade (missão a cumprir) - não atualização (passividade) - não acabamento (missão não cumprida).

$\mathrm{Na}$ estrutura da narrativa cinematográfica, é necessário considerar a participação de todos os elementos que se associam com os diálogos organizados

Dessa forma, o cinema passou a "contar histórias", já que não tinha a vocação de narrá-las por procedimentos específicos (Vernet, 1995).

${ }^{38}$ Segundo Vernet (1995), qualquer objeto representado no cinema, por mais estático que seja, a exemplo de uma paisagem, pelo simples fato de ser filmado, está sujeito à duração e à transformação.

39 Em linhas gerais, Bremond (1973) propõe uma análise estrutural da narrativa classificando os acontecimentos em dois tipos fundamentais: degradação previsível e melhoramento a obter. Para o autor, uma seqüência narrativa (unidade que compreende uma sucessão de "átomos narrativos" unidos por uma relação de solidariedade\} resulta da combinação de três fases do desenrolar de qualquer processo: virtualidade, atualização e acabamento. Nesse sentido, a seqüência narrativa comporta momentos de risco e são essas seqüências elementares que, combinadas, constituem os fios da história e constróem seqüências mais complexas, cujas configurações típicas são o encadeamento, o encaixe e a alternância. 
numa determinada seqüência. A narrativa é o enunciado em sua materialidade, que se encarrega da história a ser contada. “[...] esse enunciado que, no romance, é formado apenas de língua, no cinema, compreende imagens, palavras, menções escritas, ruídos e música, o que já torna a organização da narrativa fílmica mais complexa. [...]” (Vernet, 1995, p. 106).

Para o autor, dada a complexidade do cinema narrativo, em linhas gerais seus elementos devem estar organizados de acordo com algumas exigências, entre as quais são fundamentais: a) a denotação, que permite o reconhecimento dos objetos e das ações mostradas na imagem, ou seja, a organização da narrativa deve estabelecer o primeiro nível de leitura do filme; b) a coerência interna do conjunto narrativo, que se estabelece em função de fatores como estilo do diretor, gênero no qual a narrativa se insere, período histórico no qual é produzida; c) a ordem da narrativa e seu ritmo, que são estabelecidos em função de um encaminhamento de leitura que é imposto ao espectador. Assim, consideram-se os efeitos narrativos (humor, suspense, surpresa etc.).

Mas a ordem da narrativa cinematográfica não é simplesmente linear, podendo ser entendida como uma rede significante, um tecido de fios entrecruzados, em que um elemento narrativo pode pertencer a muitos circuitos. Nesse sentido, nem tudo no cinema narrativo é narrativo-representativo. "O cinema narrativo dispõe [...] de todo um material visual que não é 
representativo: os escurecimentos e as aberturas, a panorâmica corrida, os jogos ‘estéticos’ de cor e composição” (Vernet, 1995, p. 92).

O mesmo aspecto observa Lefebve (1975), para quem os objetos da diegese $^{40}$, no cinema, não são dados apenas segundo duas dimensões, tal como a encenação e o diálogo dramático ou cômico. Além desses campos, existe um estilo cinematográfico como há um estilo e uma caracterização do ator. A experimentação da linguagem cinematográfica na filmagem, planos longos ou curtos, perspectiva alterada pela câmera, o jogo de cores, a montagem constituem outros artifícios propriamente narrativos. Para certos processos, como o flash-back, mantêm-se em aberto à questão de saber se antes pertencem à narração ou à diegese.

Algumas aberturas de filmes, nas quais os créditos mesclam-se com o início da história, após um prólogo, podem ser consideradas diegéticas, por estarem inseridas no campo da narrativa. Outras, são claramente extradiegéticas, uma vez que se situam no plano da narração. 0 importante, numa análise da narrativa fílmica, é saber distinguir o limite entre um campo e outro, que, de fato, é tênue.

Segundo Vernet (1995) é fundamental não esquecermos de que a estreita interação entre cinema e narrativa permitem estabelecer um modelo próprio ao

\footnotetext{
${ }^{40}$ Em linhas gerais, o espaço-tempo onde se desenvolve a ação e vivem as personagens.
} 
narrativo cinematográfico, diferente, segundo certos aspectos, de um narrativo teatral ou romanesco. Uma demonstração da existência de um modelo próprio do cinema narrativo é a absorção, pelo romance contemporâneo, das técnicas cinematográficas: montagem, cortes bruscos, simultaneidade.

Entre os diversos traços dos filmes narrativos, um princípio tradicional da narração é proporcionar ao espectador a impressão de um desenvolvimento lógico que deve necessariamente desembocar num fim, numa solução. Por seu turno, a maneira de filmar uma cena orienta seu sentido, gerando efeitos narrativos diversos, como aponta Vernet: “Filmar a função 'perseguição' (unidade narrativa) em montagem alternada de planos 'perseguidoresperseguidos (figura significante cinematográfica) terá um efeito narrativo diferente de uma filmagem, a partir de um helicóptero, em plano-seqüência (ou outra figura cinematográfica) [...]” (1995, p. 97).

A primeira forma de tratamento, ao acelerar o ritmo narrativo pela montagem alternada, poderá ter um efeito de intensificação do suspense, enquanto a segunda maneira provavelmente colocará em evidência o esforço e o cansaço dos perseguidos em sua vã empreitada, ao destacar em plano-sequiência aéreo a imensidão da área que deverão percorrer para escapar de onde estavam confinados. Essa questão do efeito narrativo relaciona-se intrinsecamente com a noção de ponto de vista ou foco narrativo. 
Mas antes de nos determos no conceito de ponto de vista, vejamos como Lefebve (1975) diferencia narração e narrativa no campo literário ${ }^{41}$. Existe uma distinção e ligação estreita entre, de um lado, o discurso verbal que nos instrui sobre um mundo suposto como real, a narração (que também, por vezes, se diz enunciação), e, no outro extremo, esse próprio mundo (lugares, tempo, personagens, ações), a narrativa propriamente dita (ou ficção, ou representação ${ }^{42}$, ou, ainda, diegese). Também podemos circunscrever a narrativa como enunciado. Nessa perspectiva, qualquer narrativa, em princípio, apresentase como um mecanismo constituído por narração e diegese, podendo ser sintetizado no seguinte esquema:

narrativa $=$ narração $->$ diegese

Para Genette (1972), na narratologia a enunciação caracteriza-se como “o ato narrativo produtor”, que corresponde à instância da narração. Nessa acepção, o discurso das personagens funciona como um simulacro do ato enunciativo, no interior do próprio discurso narrativo, ou seja, no universo espaço-temporal dos eventos narrados.

\footnotetext{
${ }^{41}$ Por considerarmos complexo o cinema narrativo, que, na sua origem, inspirou-se na narrativa romanesca para criar suas próprias formas de dispor acontecimentos e estabelecer as ações das personagens, adotamos a noção literária de diegese para delimitar o discurso narrativo.

42 Termo empregado por Aumont et al., que define o cinema "representativo e narrativo", cujas fronteiras são difíceis de traçar, como o conjunto de filmes que "[...] contam uma história situando-a num certo universo imaginário que eles materializam pela representação" (1995, p. 26).
} 
No entanto, Lefebve (1975) assinala que é difícil precisar as fronteiras entre narração e diegese, apesar de a diegese não existir por si mesma. Desse modo, não se pode dizer com precisão onde a diegese (o espaço-tempo imaginário em que vivem as personagens) começa e acaba na narração. Em razão da sua natureza imaginária, é difícil determinar os elementos próprios da diegese, bem como a sua estrutura e seus limites. "A diegese confunde-se com os sentimentos que transmite e, ao mesmo tempo, distingue-se deles. Por isso, constitui um discurso. Todo o elemento da diegese é considerado como real [da realidade fictícia], mas também como um signo, um símbolo ou um indício ${ }^{43 ”}$ (Lefebve, 1975, p. 191).

Há uma imbricação da narração com a diegese. Essa estreita relação “narração-diegese” está na origem do caráter imaginário da narrativa. 0 mundo da diegese está, portanto, descolado da realidade prática. Nele “vivemos” um tempo, um espaço, uma sucessão, uma causalidade, simultaneamente semelhantes e alheios aos da nossa vida real. Nesse sentido, "a narração indica a diegese, mas ao mesmo tempo dissimula-a e denuncia-a", pois, com efeito, existe entre narração e diegese a mesma relação que entre significante e significado na linguagem, mas, aponta o autor, com uma pequena diferença: esse significado é automaticamente “presentificado", pois nos é dado simultaneamente como imaginário e como real; solicita-se-nos que o aceitemos como verdadeiro, mas também como fictício.

\footnotetext{
${ }^{43}$ Diz o autor, "segundo a expressão de R. Barthes em 'Analyse structurale des récits', Communications, $\mathrm{n}^{\circ} 8$ ".
} 
Posto que a diegese é concebida como o conjunto dos elementos que é dado como real, para compreendê-la de fato faz-se necessário entender a natureza e a extensão desses elementos: situações, ações, personagens, juízos emitidos, implicações ideológicas etc. No universo diegético, cada coisa significa. Toda ação supõe um acontecimento a vir, e todo ato e objeto são portadores de uma conotação social. Articulando essa noção com a narrativa chanchadesca, tomamos como exemplo o filme O homem do Sputnik (1959), em que o ato de Anastácio Fortuna (o herói caipira do enredo, interpretado por Oscarito) esconder o suposto satélite russo Sputnik no fundo do poço artesiano de sua casa, segundo a orientação do colunista social e jornalista Jacinto Pouchard (o herói bom moço da trama, encarnado por Cyll Farney), supõe uma intenção e uma cena futura, em que o Sputnik e os heróis desempenharão, naturalmente, um papel, qual seja: despistar os agentes dos governos imperialistas russo, americano e francês que entram na "Guerra Fria" pelo domínio da corrida espacial.

Em O camelô da Rua Larga (1958), duas malas têm funções conotativas diversas: uma delas é a mala do camelô Vicente (Zé Trindade), um malandro "boa praça” que vende bugigangas na rua que dá nome ao título do filme e, por esse motivo, vive fugindo do "rapa" (da batida policial) com seus artigos escondidos numa mala. No espaço diegético dessa chanchada, a mala de Vicente, apesar de abrigar produtos contrabandeados, representa a vida itinerante e o ganha-pão do camelô (o homem simples brasileiro que precisa ser versátil e 
criativo para ganhar dinheiro em um país com alto índice de inflação e desemprego). A outra mala, que é trocada por Vicente por engano no camarim de uma casa de shows musicais, tem uma conotação moral positiva para o desfecho da história, mas com um sentido completamente diferente da primeira mala. Na segunda mala, o camelô e seu amigo jornalista, Fernando (Allan Lima), encontram dinheiro falsificado, abrindo caminho para que uma quadrilha de falsários seja detida. Ou seja, a conotação moral é de que o crime não compensa.

Esses elementos da narrativa formam um sistema dotado de uma certa completude, isto é, cada um deles reenvia necessariamente a todos os outros. Mas esse indício, conforme pontua Lefebve (1975), é também a narrativa na sua totalidade que pode apresentar-se como símbolo. Em O homem do Sputnik (1959), por exemplo, a abundância de livros numa estante do gabinete do chefe de Estado russo é um indício do dogmatismo comunista, parodiado no filme.

Para Genette $\left(1972^{44} ; 1983\right)$, a diegese está relacionada com o universo espaço-temporal onde se desenrola a história, representando portanto o local do significado, o “mundo possível” que enquadra, valida e confere inteligibilidade à história. Ao transpor essa concepção para o cinema, Vernet (1995) entende diegese como o espaço das relações entre um conjunto significante e um conjunto significado, dado que apenas o fato de o cinema representar um objeto de forma que ele seja reconhecido é um ato que implica que se quer dizer algo a 
propósito desse objeto. Considerando essa perspectiva, tomamos como exemplo a imagem de um "pandeiro" em um filme chanchadesco. Por estar inserida em um número musical ou figurar em outra cena qualquer, essa imagem não corresponde, apenas, ao termo "pandeiro", pois transmite, implicitamente, um enunciado do tipo “eis um pandeiro" ou “isto é um pandeiro", cuja intenção é fazer com que o objeto signifique algo além de sua simples representação, pois, como nos lembra Vernet, “[...] qualquer objeto já é signo de outra coisa, já está preso em um imaginário social e oferece-se, então, como o suporte de uma pequena ficção" (1995, p. 101).

No cinema, assim como no teatro, a encenação apresentada é um fragmento de uma continuidade mais vasta que se estende para além dos limites espaciais e temporais da narrativa. No momento em que o filme é projetado, já existe uma ação. A cena em que se passa a ação reenvia necessariamente a um mundo exterior em que outras ações e outros fatos intervêm, os quais nos são referidos apenas pela atitude ou pelas palavras das personagens, tal como na narrativa diegética (Lefebve, 1975).

Essa questão do "mundo exterior" suscita um outro problema específico do cinema: a relação entre campo e fora de campo no quadro fílmico. Segundo define Aumont et al. (1995), esses campos, apesar da evidente diferença entre ambos ("o campo é visível; o fora de campo não é”), pertencem a um mesmo

\footnotetext{
${ }^{44}$ Em Figures III (1972), Genette utiliza o termo diegese como sinônimo de história.
} 
espaço imaginário perfeitamente homogêneo, denominado pelo autor de espaço fílmico ou cena fílmica.

A importância similar desses campos decorre de o espaço fora de campo estar vinculado, essencialmente, ao campo, pois só existe em função deste. Ou seja, é a partir do campo (a porção de espaço imaginário que está contida dentro do quadro), que se percebe o fora de campo, no qual não há mais imagem, mas se faz existente em torno do campo.

O autor qualifica o campo e o fora de campo como espaços igualmente imaginários; primeiro, porque considera o caráter imaginário do campo ("que decerto é visível, 'concreto', se quisermos, mas nada tangível”), e, segundo, em razão da homogeneidade e reversibilidade entre campo e fora de campo, uma vez que ambas são importantes para a definição do espaço fílmico:

\footnotetext{
Essa igual importância tem, aliás, um outro motivo, o fato de a cena fílmica não se definir unicamente por traços visuais; em primeiro lugar, o som nela desempenha um grande papel; ora, entre o som emitido 'dentro do campo' e um som emitido 'fora de campo', o ouvido não conseguiria estabelecer a diferença; essa homogeneidade sonora é um dos grandes fatores de unificação do espaço fílmico por inteiro. Por outro lado, o desenvolvimento temporal da história contada, da narrativa, impõe que se leve em consideração a passagem permanente do campo para fora de campo, portanto, sua comunicação imediata [...] (Aumont et al., 1995, p. 25).
}

Há outras abordagens sobre a noção de fora de campo, como a de Pascal Bonitzer (1976), que propõe a idéia de um fora de campo heterogêneo ao campo, o qual poderia ser definido como o "espaço da produção" (no sentido lato da 
terminologia). Este espaço seria aquele em que funciona a aparelhagem técnica, o trabalho de direção e, metaforicamente, o trabalho de escrita ${ }^{45}$.

Nesta investigação, conservaremos a noção de fora de campo como espaço fílmico, homogêneo ao campo, tal como a define Aumont et al. (1995). Para delimitar o "espaço da produção", também em consonância com o autor, adotaremos a terminologia fora de quadro, idéia que se refere ao "artefato da produção do filme”.

De acordo com Metz (1972) e Vernet (1995), é dentro do texto fílmico, na sua narrativa, que se encontram os indícios da enunciação desse texto. Contudo, Metz (1991) pontua que não devemos limitar a enunciação fílmica à enunciação verbal (partes dialogadas de um filme, a “conversa”), apesar de os diálogos fílmicos empregarem o aparelho dêitico ${ }^{46}$. Numa interlocução verbal oral, os dêiticos fornecem informações sobre a enunciação através da própria enunciação, enquanto os dêiticos dos diálogos de um filme fornecem informações não sobre a enunciação do filme, mas sobre uma enunciação interna, ela mesma enunciada pelo filme. Desse modo, o autor propõe que se conceba "[...] um aparelho enunciativo que não seja essencialmente dêitico (e portanto

\footnotetext{
${ }^{45}$ Apesar da interessante questão originada por esta visão de "espaço da produção", que enfatiza o "engodo que a representação fílmica constitui, ocultando [...] sistematicamente qualquer vestígio de sua própria produção" (Aumont et al., 1995, p. 29), no âmbito deste estudo não nos deteremos detalhadamente nesta abordagem. As condições em que foram produzidas as chanchadas e como se posicionavam diretores e atores estão vinculadas ao próprio discurso chanchadesco.

46 "Chama-se dêitico qualquer marca, qualquer indicador que remete tanto ao locutor quanto à situação de enunciação. Os mais comuns são os pronomes pessoais, os pronomes e adjetivos
} 
antropomorfo), pessoal (como os pronomes denominados dessa maneira) e que não imite tão de perto este ou aquele dispositivo lingüístico” (Metz, 1991, p. 21).

Coerentes com as teorias da AD francesa e os princípios bakhtinianos do discurso dialógico, entendemos que uma análise da narrativa fílmica deve visar à apreensão do discurso ideológico do cinema, uma vez que concebemos o cinema como veículo dos discursos que circulam socialmente em um determinado contexto histórico. Nesse prisma, as tipologias de personagem podem ser consideradas representativas não apenas de um período do cinema como também de um período da sociedade.

É nessa perspectiva que as noções bakhtinianas de dialogismo e gêneros discursivos tornam-se centrais para este estudo. As tipologias de personagem (o malandro, o bom moço, a boa moça, o caipira, o artista de rádio, cinema e televisão, o jornalista, o diretor de cinema e produtor de TV, o palhaço, o trabalhador assalariado) e de intradiscursos (parodístico, irônico, satírico, caricatural) que identificamos na narrativa chanchadesca dialogam com diversos segmentos sociais dos anos 50, e a mídia apresenta-se como um dos principais elementos desse discurso cinematográfico. Na narrativa fílmica, o dialogismo compreende a confrontação de pontos de vista, ideologias e valorações de cuja articulação deduzimos a estrutura do universo ficcional representado. 
É no espaço-tempo narrativo que buscaremos conhecer o diálogo da chanchada com a mídia. Nesta pesquisa, o dialogismo é considerado como a relação interativa entre os processos discursivos nos planos lingüísticos e metalingüísticos, da qual decorre a produção de sentidos. É nessa perspectiva que adotamos a noção de discurso dialógico na investigação do diálogo da chanchada com a mídia nos anos 50, isto é, na apreensão do discurso narrativodialógico do gênero prosaico chanchada.

Ao situarmos esta investigação no campo das relações dialógicas entre meios de comunicação, faz-se necessário pontuarmos a nossa concepção de mídia. Para tanto, tomamos como referência a noção de Thompson (1995; 1998) a respeito da mídia, que a define como um sistema cultural complexo que, por um lado, compreende uma dimensão simbólica que abarca a construção, o armazenamento, a reprodução e a circulação de produtos carregados de sentidos, tanto para seus enunciadores (os media) como para os enunciatários (seus leitores, espectadores etc.). Por outra parte, possui uma dimensão contextual (espaço-temporal), uma vez que esses produtos midiáticos são fenômenos sociais.

Em relação às mídias em pauta neste estudo (impressa, rádio, televisão e cinema), percebemo-las como meios que se relacionam com toda ficção produzida a partir da segunda metade do século XX, em processos de adaptação, de reprodução ou de recriação ficcional. A estreita relação entre mídia e 
narração, mídia e ficção, constitui-se nos meios de comunicação através das linguagens que lhes são próprias e predominantes, ou seja, a linguagem verbal na imprensa (jornal/revista), a oral no rádio e a verbo-visual na televisão e no cinema. Tomadas como meios de narração, essas mídias interagem umas com as outras numa rede dialógica em que seus universos narrativos se interpenetram.

\subsubsection{PONTO DE VISTA}

A questão do ponto de vista ou foco narrativo, do qual emana a "voz narrativa" é estudada por diversos autores e não se reduz ao ângulo a partir do qual se conta a história. 0 narrador pode se esconder atrás da história para dar a impressão de que esta evolui por si mesma como se fosse autônoma, deixando a trama correr livremente, como se fosse observada de uma "janela transparente", ou intervir, explicitando suas opiniões. Ou, ainda, assumir a posição de narrador onisciente, que tudo sabe. Outras vezes, faz com que saibamos mais do que as próprias personagens. Enfim, o narrador escolhe as posições que situa as personagens de acordo com o seu objetivo narrativo (Xavier, 2003).

Lefebve nos lembra que a narrativa "nunca nos fornece senão precisamente uma 'visão', isto é, uma perspectiva necessariamente incompleta, lacunar, ‘anamorfoseada' de um certo real” (1975, p. 186). Ao adotar um ponto de vista sobre o real, toda narrativa é subjetiva e ideológica. 
A possibilidade de um observador descobrir novos ângulos em relação ao que é observado é extremamente valorizada por Bakhtin. É nesse sentido que o dialogismo configura-se como o processo de interação com o outro segundo a multiplicidade dos pontos de visão. Para o autor, a focalização é determinada pela lei do posicionamento, a qual determina o prisma do campo visual e conduz a percepção do sujeito. Mas o olhar que o sujeito lança ao mundo cria uma simultaneidade de percepções, de tal forma que o ponto de vista único não implica uma unicidade de configuração. Por um lado, a percepção é ativada por um único foco; por outra parte objeto ou evento pode ter uma focalização múltipla e simultânea, considerando-se os espectros de perspectivas possíveis que nele incidem (Machado, 1995).

A focalização que nos interessa neste estudo é o ponto de vista das personagens, pois entendemos que é por meio do discurso encarnado por alguns tipos criados pela chanchada, como o jornalista, o diretor de cinema, a artista ou o produtor de televisão, o locutor de rádio, ou outras personagens que se relacionam com os meios de comunicação, que a chanchada dialoga de forma mais direta com a mídia de sua época.

\subsubsection{ESPAÇO-TEMPO}

A relação espaço-tempo apresenta-se como uma instância narrativa essencial para a análise de qualquer discurso diegético, pois como assinala 
Bakhtin, "em arte e em literatura, todas as definições espaço-temporais são inseparáveis umas das outras [...]” (1993a, p. 349).

Nesta pesquisa, interessa-nos a apreensão do espaço narrativo como "espaço social”, que se configura em função da presença de tipos e figurantes que ilustram, numa dada dinâmica temporal, os ambientes e segmentos sociais. A relação do espaço com o tempo, a transformação de uma disposiçãa espacial numa disposição temporal, encontra-se fortemente condicionada pelo ponto de vista, seja quando este se limita a uma descrição exterior, seja quando ativa a focalização interna de uma personagem.

À integração indissolúvel do tempo no espaço Bakhtin denomina de cronotopo, o qual consiste no centro organizador dos principais acontecimentos temáticos da narrativa, em que os nós do enredo são feitos e desfeitos, os acontecimentos se concretizam e ganham corpo. No cronotopo, o tempo é tido como uma quarta dimensão de espaço. Resumidamente, Bakhtin define cronotopo artístico-literário como uma instância narrativa na qual

ocorre a fusão dos indícios espaciais e temporais num todo compreensivo e concreto. [...] o tempo comprime-se, condensa-se, torna-se artisticamente visível; o próprio espaço intensifica-se, penetra no movimento do tempo, do enredo e da história. Os índices do tempo transparecem no espaço, e o espaço reveste-se de sentido e é medido com o tempo (1993a, p. 211). 
$\mathrm{Na}$ perspectiva que observamos o espaço-tempo, com atributos de natureza sócio-histórica, este nos remete para o sistema ideológico que se apresenta de forma predominante na narrativa.

\subsection{METODOLOGIA}

\subsubsection{CONSTITUIÇÃO DO CORPUS}

A constituição do corpus desta investigação originou-se da hipótese de que a chanchada, um gênero cinematográfico estigmatizado como subproduto cultural pelos meios de comunicação de sua época, teria constituído um discurso crítico sobre esses meios, estabelecendo uma relação dialógica com a imprensa (jornal/revista), o rádio, a televisão e o próprio cinema. A partir dessa premissa, formulamos algumas indagações que nos orientaram na seleção do corpus, quais sejam: a) Em que período socio-histórico esse diálogo foi mais recorrente? b) Sob que ângulo ou ponto de vista esse diálogo se processou? c) Quais vozes permeiam esse diálogo? d) Quais são as similitudes entre os diálogos estabelecidos pela chanchada com cada meio e qual discurso se apresenta como eixo central nessa rede interdiscursiva?

O levantamento preliminar dos dados identificou, entre os anos 40,50 e 60, vinte e seis filmes chanchadescos que se referem não apenas à imprensa, mas também ao rádio, à televisão e ao cinema: 
1) Carnaval no fogo (1949/Atlântida/Rio de Janeiro), em que o rádio tem a dupla função de divertir e informar; 2) Estou aí (1949/Cine Produções Fenelon-Estúdios Cinédia/Rio de Janeiro), com a personagem Diretor da Rádio (Ronaldo Lupo); 3) Agüenta firme, Izidoro (1950/Rio de Janeiro/Estúdios Cinédia), em que duas personagens são Locutores de Rádio; 4) Carnaval Atlântida (1952/Atlântida/Rio de Janeiro), em que manchetes de revistas servem de cenário a um número musical em um estúdio cinematográfico, com as personagens Diretor de Cinema/Cecílio B. de Milho (Renato Restier) - uma paródia ao diretor norte-americano Cecil B. de Mille -, e Professor de História Grega/Roteirista (Oscarito); 5) Carnaval em Caxias (1953/Flama-Atlântida/Rio de Janeiro), com Jece Valadão interpretando um Camelô e Locutor de Rádio; 6) Carnaval em Marte (1954/Brasil Vita/Rio de Janeiro), com Anselmo Duarte como Repórter; 7) Nem Sansão nem Dalila (1954/Atlântida/Rio de Janeiro), em que o ditador Sansão (Oscarito) interfere na programação da "Rádio" do "Reino de Gaza"; 8) Carnaval em lá maior (1955/Maristela-Emissoras Unidas/São Paulo), com a personagem Diretor de TV (Blota Jr.); 9) Vamos com calma (1955/Atlântida/Rio de Janeiro), com abordagem sobre o mundo do Rádio; 10) Com água na boca (1956/Herbert Richers/Rio de Janeiro), em que há o Diretor de TV (Zeloni), e os palhaços Carequinha (Carequinha) e Fred (Fred Villar) e a Mocinha/Marina (Anilza Leoni), que se tornam estrelas de TV; 11) Rio fantasia (1956/Watson Macedo/Rio de Janeiro), em que um aparelho de TV é comprado, numa modesta pensão, para que os hóspedes assistam à estréia da amiga-hóspede (Eliana) como artista de televisão; 12) $A$ baronesa transviada (1957/Watson Macedo/Rio de Janeiro), em que a manicure Gonçalina Piaçava (Dercy Gonçalves) torna-se estrela e produtora de uma comédia cinematográfica, é entrevistada por um Repórter (Pedro Farah) e trabalha em um estúdio em que atuam as personagens Produtor de Cinema (Guillermo Masseratti), Diretor de Cinema (Catalano) e atriz de cinema (Suely Borel); 13) Absolutamente certo (1957/Cinedistri/São Paulo), em que há as personagens Televisinha/Dona Bela (Dercy Gonçalves), Apresentador de Programa de Auditório/Aurélio Campos (Luiz Orini) e Locutor Esportivo de TV (Pedro Luiz); 14) Com jeito vai (1957/CinedistriHerbert Richers/Rio de Janeiro), em que há um Fotógrafo (Chiquinho); 15) De vento em popa (1957/Atlântida/Rio de Janeiro), em que a personagem Eloína (Eloína), uma empregada doméstica, define entrevista como "tudo aquilo que a gente não diz e sai publicado" e um falso professor, Max Scott (Oscarito), fala com a imprensa por meio de "códigos secretos" durante uma coletiva; 16) Garotas e samba (1957/Atlântida/Rio de Janeiro), que se refere ao mundo do Rádio; 17) O camelô da Rua Larga (1958/Cinedistri/Rio de Janeiro), em que um Repórter Policial (Allan Lima) abre caminho para a captura de uma quadrilha de falsários; 18) Vou te contá (1958/Maristela/São Paulo), com a personagem Repórter (Pagano Sobrinho); 19) Garota enxuta (1959/Herbert Richers/Rio de Janeiro), em que Nelly (Nelly Martins) passa por filha do presidente Aporonga Popó (Ankito) para conseguir um lugar como cantora em programa de TV; 20) Massagista de madame (1959/Herbert Richers/Rio de Janeiro), em que um Repórter Fotográfico (Wilton 
Franco) carrega no crachá a palavra "press" e Zé Trindade encarna um Colunista Social "invisível"; 21) 0 homem do Sputnik (1959/Atlântida/Rio de Janeiro), com Cyll Farney como o Colunista Social Jacinto Pouchard do jornal "Tribuna da Cidade"; 22) Marido de mulher boa (1960/Herbert Richers/Rio de Janeiro), com a personagem Técnico de TV (Geraldo Alves); 23) Vai que é mole (1960/Herbert Richers/Rio de Janeiro), em que Renata Fronzi interpreta uma colunista de fofocas do mundo artístico; 24) $O$ dono da bola (1961/Herbert Richers/Rio de Janeiro), com referência a um programa de auditório televisivo; 25) Três colegas de batina (1961/ Watson Macedo-Cinedistri/Rio de Janeiro), em que Chacrinha encarna um fotógrafo; 26) Virou bagunça (1961/Watson MacedoCinedistri/Rio de Janeiro), com as personagens diretor de TV (Nicolino Cupello) e rapaz da TV (Gonzaga Vasconcelos) (Lima, 2002; Sérgio Augusto, 1989; Dias, 1993).

Essa constatação nos levou a empreender uma segunda leitura horizontal sobre o corpus, a qual nos permitiu observar uma maior reincidência dos meios de comunicação nas chanchadas produzidas a partir dos anos 50 , muitas delas recordistas de bilheteria, a exemplo de O homem do Sputnik (1959), que centralizou sua temática na produção da notícia numa redação de jornal. Ao delimitarmos, por fim, a investigação na década de 50, selecionamos dezenove chanchadas daquele período, quais sejam:

1) Agüenta firme, Izidoro (1950/Rio de Janeiro/Estúdios Cinédia), em que duas personagens são Locutores de Rádio; 2) Carnaval Atlântida (1952/Atlântida/Rio de Janeiro), em que manchetes de revistas servem de cenário a um número musical em um estúdio cinematográfico, com as personagens Diretor de Cinema/Cecílio B. de Milho (Renato Restier) - uma paródia ao diretor norte-americano Cecil B. de Mille -, e Professor de História Grega/Roteirista (Oscarito); 3) Carnaval em Caxias (1953/Flama-Atlântida/Rio de Janeiro), com Jece Valadão interpretando um Camelô e Locutor de Rádio; 4) Nem Sansão nem Dalila (1954/Atlântida/Rio de Janeiro), em que o ditador Sansão (Oscarito) interfere na programação da "Rádio" do "Reino de Gaza"; 5) Carnaval em Marte (1954/Brasil Vita/Rio de Janeiro), com Anselmo Duarte como Repórter; 6) Carnaval em lá maior (1955/Maristela-Emissoras Unidas/São Paulo), com a personagem Diretor de TV (Blota Jr.); 7) Vamos com calma (1955/Atlântida/Rio de Janeiro), com abordagem sobre o mundo do Rádio; 8) Com água na boca (1956/Herbert Richers/Rio de Janeiro), em que há o Diretor de TV (Zeloni), e os palhaços Carequinha 
(Carequinha) e Fred (Fred Villar) e a Mocinha/Marina (Anilza Leoni), que se tornam estrelas de TV; 9) Rio fantasia (1956/Watson Macedo/Rio de Janeiro), em que um aparelho de TV é comprado, numa modesta pensão, para que os hóspedes assistam à estréia da amiga-hóspede (Eliana) como artista de televisão; 10) A baronesa transviada (1957/Watson Macedo/Rio de Janeiro), em que a manicure Gonçalina Piaçava (Dercy Gonçalves) torna-se estrela e produtora de uma comédia cinematográfica, é entrevistada por um Repórter (Pedro Farah) e trabalha em um estúdio onde há as personagens Produtor de Cinema (Guillermo Masseratti), Diretor de Cinema (Catalano) e atriz de cinema (Suely Borel); 11) Absolutamente certo (1957/Cinedistri/São Paulo), em que há as personagens Televisinha/Dona Bela (Dercy Gonçalves), Apresentador de Programa de Auditório/Aurélio Campos (Luiz Orini) e Locutor Esportivo de TV (Pedro Luiz); 12) Com jeito vai (1957/CinedistriHerbert Richers/Rio de Janeiro), em que há um Fotógrafo (Chiquinho); 13) De vento em popa (1957/Atlântida/Rio de Janeiro), em que a personagem Eloína (Eloína), uma empregada doméstica, define entrevista como "tudo aquilo que a gente não diz e sai publicado" e um falso professor, Max Scott (Oscarito), fala com a imprensa por meio de "códigos secretos" durante uma coletiva; 14) Garotas e samba (1957/Atlântida/Rio de Janeiro), que se refere ao mundo do Rádio; 15) O camelô da Rua Larga (1958/Cinedistri/Rio de Janeiro), em que um Repórter Policial (Allan Lima) abre caminho para a captura de uma quadrilha de falsários; 16) Vou te contá (1958/Maristela/São Paulo), com a personagem Repórter (Pagano Sobrinho); 17) Garota enxuta (1959/Herbert Richers/Rio de Janeiro), em que Nelly (Nelly Martins) passa por filha do presidente Aporonga Popó (Ankito) para conseguir um lugar como cantora em programa de TV; 18) Massagista de madame (1959/Herbert Richers/Rio de Janeiro), em que um Repórter Fotográfico (Wilton Franco) carrega no crachá a palavra "press" e Zé Trindade encarna um Colunista Social "invisível"; 19) O homem do Sputnik (1959/Atlântida/Rio de Janeiro), com Cyll Farney como o Colunista Social Jacinto Pouchard do jornal "Tribuna da Cidade" (Lima, 2002; Sérgio Augusto, 1989; Dias, 1993).

A título de registro do caminho percorrido na construção do recorte, não podemos deixar de citar as sete películas que, apesar de se referirem à mídia, foram excluídas do corpus, em razão de terem sido produzidas nas décadas de 40 e 60:

1) Carnaval no fogo (1949/Atlântida/Rio de Janeiro), em que o rádio tem a dupla função de divertir e informar; 2) Estou aí (1949/Cine Produções Fenelon-Estúdios Cinédia/Rio de Janeiro), com a 
personagem Diretor da Rádio (Ronaldo Lupo); 3) Vai que é mole (1960/Herbert Richers/Rio de Janeiro), em que Renata Fronzi interpreta uma colunista de fofocas do mundo artístico; 4) Marido de mulher boa (1960/Herbert Richers/Rio de Janeiro), com a personagem Técnico de TV (Geraldo Alves); 5) 0 dono da bola (1961/Herbert Richers/Rio de Janeiro), com referência a um programa de auditório televisivo; 6) Virou bagunça (1961/Watson Macedo-Cinedistri/Rio de Janeiro), com as personagens diretor de TV (Nicolino Cupello) e rapaz da TV (Gonzaga Vasconcelos); 7) Três colegas de batina (1961/Watson Macedo-Cinedistri/Rio de Janeiro), em que Chacrinha encarna um fotógrafo (Lima, 2002; Sergio Augusto, 1989).

Para o estudo do objeto em questão, com base numa terceira filtragem do corpus e considerando fundamentalmente os meios com os quais a chanchada relacionou-se de forma mais aproximada, ou seja, o rádio ${ }^{47}$ e o próprio cinema ${ }^{48}$, decidimos, enfim, empreender a análise em dois filmes cujas temáticas dedicamse principalmente a essas mídias, mas também se referem à televisão e à imprensa:

1) Nem Sansão nem Dalila (1954/Atlântida/Rio de Janeiro), com o enfoque no rádio ${ }^{49}$; 2) A baronesa transviada (1957/Watson Macedo/Rio de Janeiro), cuja narrativa volta-se para o cinema ${ }^{50}$.

Todo o percurso de recorte até chegar à amostragem baseou-se numa minuciosa leitura dos filmes disponíveis e em um levantamento empreendido nas filmografias contidas nos livros Este mundo é um pandeiro, de Sergio Augusto (1989), O mundo como chanchada, de Dias (1993), na monografia $A$ imagem do

\footnotetext{
${ }^{47}$ Do rádio, a chanchada herdou a linguagem lítero-musical popular dos programas de auditório e das radionovelas, além de emprestar cantores e atores.

${ }^{48}$ Por ser a chanchada um gênero pertencente ao meio cinema, preferimos aprofundar a análise da mídia cinema.

49 Este filme também menciona a televisão, em um programa de rádio, como "a maravilha do século".

${ }^{50}$ Este filme também se refere, de forma secundária, à imprensa.
} 
jornalismo na chanchada brasileira: como a Atlântida representou a imprensa em seus filmes na década de 50, de Lima (2002), e em dados pesquisados nos sites das companhias produtoras, como Atlântida, Cinedistri, entre outras.

Cabe lembrar que alguns importantes filmes realizados nos anos 50 pelas produtoras Atlântida Cinematográfica, Maristela, Cinedistri, Flama, Brasil Vita, Produções Cinematográficas Herbert Richers, entre outras, perderam-se em função da má conservação ou dificilmente são encontrados porque não existem cópias dessas chanchadas nos acervos de cinematecas, colecionadores e locadoras do circuito comercial. No caso da Atlântida, diversos títulos destruíram-se num incêndio ocorrido em seus estúdios em 1952 e numa inundação em seus depósitos em 1971.

Com efeito, a etapa de levantamento e reunião do corpus foi a que apresentou mais dificuldade para a evolução da pesquisa, exigindo um trabalho de garimpo em locadoras, na Cinemateca Brasileira e nos canais de TV a cabo que veiculam chanchadas. Os filmes em VHS disponíveis para locação foram transcodificados para DVD e os raros títulos lançados em DVD, como Absolutamente certo (1957) e A Baronesa transviada (1957), foram adquiridos para ser agrupados aos títulos circunscritos na década de 50. Superadas as dificuldades iniciais, entendemos que as quatro chanchadas escolhidas - Nem Sansão nem Dalila (1954/Atlântida); Absolutamente certo (1957/Cinedistri); A Baronesa transviada (1957/Watson Macedo); e O homem do Sputnik 
(1959/Atlântida) -, em razão do destaque que dispensam em seus enredos à imprensa, ao rádio, à televisão e ao cinema, constituem um material consistente para a análise do discurso narrativo da chanchada sobre os meios de comunicação nos anos 50 .

\subsubsection{PROCEDIMENTOS DE LEITURA DAS NARRATIVAS FÍLMICAS}

Nas primeiras leituras do material para a seleção e recorte do corpus, identificamos núcleos temáticos ou inspirações para a construção das categorias de análise. Essas categorias constituem-se no instrumental analítico básico que emerge do quadro teórico de referências empregado.

A delimitação da formação discursiva chanchada como um gênero prosaico, permitiu-nos recortar dois tipos de discursos que se nos afiguram como mais recorrentes no diálogo da chanchada com a mídia: o discurso parodístico e o discurso irônico, utilizados como recursos estilísticos com grande regularidade enunciativa nas películas chanchadescas, visando a atingir um efeito cômico ${ }^{51}$. Esses discursos, encarnados essencialmente pelas personagens, quer na caracterização, quer no ponto de vista que estas assumem, foram identificados no universo diegético dos filmes com base nos rastros enunciativos que caracterizam a paródia e a ironia.

\footnotetext{
${ }^{51}$ Os efeitos de humor na chanchada são criados por meio de diversas formas estilísticas, como paródia, ironia, sátira, caricatura, deboche, pastiche, pastelão, entre outros.
} 
No discurso parodístico, estabelece-se a assimilação de um texto primitivo, reestruturando-o e, ao mesmo tempo, negando-o, numa forma paralela de releitura do texto original, gerando uma imagem invertida, ampliada ou reduzida. No discurso irônico, por seu turno, a palavra tem duplo sentido, voltando-se para o objeto do discurso como palavra comum e para um outro discurso, numa espécie de emprego ambíguo da linguagem do outro, porém revestido de orientação oposta à do outro, contradizendo e contrariando o discurso original.

Tanto na paródia como na ironia, a fusão de vozes é impossível, pois elas provêm de mundos diferentes gerando um efeito polifônico. Esses tipos de discursos têm como traço comum a palavra com duplo sentido, voltado para o objeto do discurso enquanto palavra comum e para um outro discurso. Assim, a característica principal desses discursos é a bivocalidade da palavra dialógica, ou seja, em um só discurso ocorrem duas orientações semânticas, duas vozes.

A principal diferença entre o discurso parodístico e irônico situa-se na tênue fronteira entre negação e ambivalência: a paródia, partindo do enunciado primitivo, nega-o para reconstruir um novo enunciado com "acento" próprio; a ironia apropria-se do enunciado original para contradizê-lo, com uma idéia oposta, acentuando o duplo sentido, a ambivalência ${ }^{52}$. Bakhtin aponta a ambigüidade como elemento intrínseco aos discursos parodístico e irônico:

\footnotetext{
${ }^{52}$ A principal diferença do discurso estilizado em relação à paródia e à ironia é a manutenção do sentido criado no texto original. Na estilização, a idéia do autor não entra em choque com a
} 
Ao discurso parodístico é análogo o emprego irônico e todo emprego ambíguo do discurso do outro, pois também nesses casos esse discurso é empregado para transmitir intenções que the são hostis. No discurso prático da vida é extremamente difundido esse emprego do discurso do outro, sobretudo no diálogo em que um interlocutor muito amiúde repete literalmente a afirmação do outro interlocutor, revestindo-a de novo acento e acentuando-a a seu modo com expressões de dúvida, indignação, ironia, zombaria, deboche etc. (1997, p. 195).

Segundo a ótica bakhtiniana, no discurso irônico "a segunda voz, uma vez instalada no discurso do outro, entra em hostilidade com seu agente primitivo e o obriga a servir a fins diametralmente opostos. 0 discurso se converte em palco de luta entre vozes" (Bakhtin, 1997, p. 194).

A paródia, conforme assinala Bakhtin, é um elemento inseparável da sátira menipéia e de todos os gêneros carnavalizados, configurando-se como um discurso no qual se encontram duas orientações interpretativas que tornam a linguagem dupla, transgressora. Parodiar é criar o duplo destronante, o mesmo “mundo às avessas”; por essa razão, a paródia é ambivalente. Engolindo e transformando o texto primitivo, a paródia abarca vozes que se fazem ouvir numa leitura polifônica. O discurso parodístico pode ser bastante variado, pois se pode parodiar

o estilo de um outro enquanto estilo; pode-se parodiar a maneira típico-social ou caracterológico-individual de o outro ver, pensar e falar. Em seguida, a paródia pode ser mais ou menos profunda: podem-se parodiar apenas as formas superficiais do discurso como se

idéia do outro, mas a acompanha no sentido que esta assume, fazendo apenas este sentido tornar-se convencional. Na paródia e na ironia, "o autor também fala a linguagem do outro, 
podem parodiar até mesmo os princípios profundos do discurso do outro. [...] a despeito de todas as possíveis variedades do discurso parodístico, a relação entre o autor e a intenção do outro permanece a mesma. Essas aspirações estão orientadas para diferentes sentidos [...] $(1997$, p. 194).

Eleitas as categorias de análise (discurso parodístico e discurso irônico), a leitura foi empreendida com base em três níveis discursivos-operacionais que materializam essas categorias no espaço diegético: o verbal (representado pelos diálogos), o extra-verbal (presentificado na imagem em que transcorrem os dispositivos técnicos próprios da linguagem fílmica - planos, movimentos de câmera, ritmo da montagem - e os elementos cênicos - cenário, personagens, encenação) e o sonoro (trilhas musicais e ruídos).

Adotamos como instrumento analítico-descritivo a segmentação dos filmes em blocos narrativos (uma série de planos $^{53}$ associados por uma unidade narrativa), com base no modelo proposto por Aumont e Marie $(1988)^{54}$. Essa divisão permitiu a identificação de narratemas (unidades mínimas de uma narrativa capaz de representar um evento $)^{55}$ relacionados com os objetivos da

mas, diferentemente da estilização, reveste essa linguagem de orientação semântica diametralmente oposta à orientação do outro" (Bakhtin, 1997, 194).

53 Uma vez que o termo plano é fartamente empregado de forma empírica no vocabulário técnico do cinema, abrangendo um conjunto de parâmetros (dimensões, quadro, ponto de vista, movimento, duração, ritmo, relação com outras imagens), neste estudo delimitamos plano como unidade de duração, visto que empregamos um modelo analítico que privilegia blocos narrativos compostos de sucessivos planos. Também utilizamos o termo plano nos seguintes contextos: para descrever o tamanho (plano geral, plano médio, plano americano etc.), referirse ao movimento (plano fixo ou em movimento) e deter-se na questão do ponto de vista, já que esses elementos são essenciais para uma análise baseada na narrativa.

${ }^{54}$ Aumont e Marie (1988) propõem dois instrumentos de descrição: a decupagem (divisão do filme em planos) e a segmentação (divisão do filme em seqüências).

${ }^{55} \mathrm{O}$ termo narratema é empregado por Coste (1989). 
pesquisa. Desse modo, selecionamos e nomeamos dois narratemas, um para cada filme, quais sejam:

1) "Votai em Sansão, um homem de ação" (Nem Sansão nem Dalila - discurso parodístico)

2) "Cinema indígena" (A baronesa transviada - discurso irônico)

No nível verbal, dos diálogos, utilizamos como dispositivo auxiliar de análise o método dos termos-pivôs ${ }^{56}$, que se afina com a estrutura dos narratemas delimitados nos discursos parodístico e irônico. Com base nos termos-pivôs, examinamos os implícitos, as vozes que permeiam esses discursos, observando o modo como as marcas da enunciação se materializam no texto. Como assinala Bakhtin (1997), discursos como o parodístico e o irônico podem ser individualizados no matiz lexical se este sugerir algum enunciado de um outro ao qual dada palavra é tomada de empréstimo ou em cujo espírito ela se constrói.

Nos níveis visual e sonoro, procedemos a análise com base no ponto de vista e na tipologia das personagens, privilegiando, entre as modalidades de representação dos diferentes segmentos de informação diegética, a configuração do espaço-tempo como ambiente social. Nesse universo narrativo, não nos restringimos apenas aos componentes físicos que servem de cenário ao desenrolar da ação e à movimentação das personagens, mas à focalização, que

\footnotetext{
${ }^{56}$ Método utilizado pela $A D$ desde que possa ser empregado como um dispositivo auxiliar para a análise, que não neutralize a complexidade sintática e enunciativa, nem elimine o contexto (Maingueneau, 1989).
} 
interfere decisivamente na representação do espaço-tempo como horizonte ideológico.

A análise dos filmes iniciou-se com o processo de impregnação, ou seja, com a leitura e releitura de cada narrativa fílmica, até o domínio completo de todos os narratemas. Inicialmente procedemos à leitura, em separado, de cada um dos narratemas (leitura vertical). Após essa etapa, efetuamos a leitura do conjunto dos blocos narrativos (leitura horizontal). A leitura do conjunto de narratemas nos três níveis (verbal, visual e sonoro) permitiu estabelecer relações que viabilizam as interpretações dos sentidos e efeitos decorrentes desses discursos em relação à mídia.

\section{CAPÍTULO II - A NARRATIVA CHANCHADESCA: DOS TEMAS RURAIS AO COTIDIANO URBANO}

O discurso narrativo das primeiras chanchadas centrava-se nas temáticas carnavalescas - princípio que o gênero nunca abandonou -, rurais ou juninas, alinhavadas com números musicais criados para divulgar as marchinhas de carnaval. O efeito cômico nas chanchadas era criado pela repetição de situações comuns à comédia - o pastelão, o pastiche, o travestimento ou o simples aparecimento de um ator-personagem conhecido. A partir da segunda metade dos anos 40, quando o gênero começou a incorporar a crítica social ao cotidiano urbano, os temas rurais e juninos foram sendo abandonados e a sua narrativa 
tornou-se mais complexa. Os enredos passaram a narrar histórias que se desenvolvem nos centros urbanos.

Tratam do homem urbano que se desumaniza, da deficiência do transporte coletivo, do alto preço do leite, da classe médica ineficiente, da falta d’água, da poluição na Lagoa Rodrigo de Freitas, da política populista do governo federal, da construção de Brasília, do rádio, da imprensa, do cinema e da televisão.

Na década de 50, a narrativa da chanchada já não se pautava apenas em caricaturas e na imitação, mas se constrói na paródia ao cinema hollywoodiano, com astros e estrelas do teatro de revista, números musicais de cantores e cantoras de rádio, temas carnavalescos e piadas sobre as mazelas cotidianas dos brasileiros. Quando se aprimorou nas tramas, inseriu outro ingrediente: a intriga amorosa com um desenrolar conhecido e com final feliz. E a paródia, amplamente utilizada nos filmes de José Carlos Burle (Carnaval Atlântida) e Carlos Manga (Nem Sansão nem Dalila; Matar ou Correr), produzidos pela Atlântida.

A chanchada é um gênero de comédia investido dos elementos da narrativa clássica do cinema, baseada nos musicais de hollywoodianos, que se valem da sucessão de campo e contra-campo, de planos em close, de planos médios e abertos, movimentos simples de câmera, enfim, de uma linguagem a serviço do ato narrativo baseado no cômico-popular. 
Em meio aos baixos orçamentos e à narrativa linear presente na maioria dos filmes chanchadescos, há amostras de "sofisticação": em O homem do Sputnik (Atlântida/1959), por exemplo, a abertura dos créditos constitui-se uma narrativa extradiegética cujo discurso refere-se, por meio de formas geométricas em estilo Oscar Niemeyer, à nova capital federal (Brasília, que substituirá, em breve, a sede do poder, até então no Rio de Janeiro). O enunciado dessa abertura reflete, ainda, o avanço tecnológico e a corrida espacial, a modernidade que chega ao Brasil. Apesar de discursos elaborados como este, a linguagem cinematográfica da chanchada não utilizou recursos técnicos sofisticados como montagem vertical, câmera solta ou planos longos, nem planos-seqüência, comuns ao cinema experimental da época, como o cinema novo, que ensaiava os primeiros passos no fim da década de 50 . Até porque as produções chanchadescas eram feitas às pressas, em escala industrial e com baixos orçamentos. É evidente que, na maioria dos filmes do gênero, a maior parte dos atores não interpretam a contento. Há nas chanchadas, sem sombra de dúvida, uma precariedade, que levou os críticos a considerá-las comédias apressadas sem conteúdo.

No entanto, é da falta, da carência de recursos, que o gênero encontra alternativas criativas para produzir filmes. O homem do Sputnik (1959) e De vento em popa (Atlântida/1957), premiado pela crítica como o melhor filme daquele ano, são chanchadas que se destacam por terem aprimorado os 
elementos que caracterizam a narrativa chanchadesca: musical carnavalesco, humor e crítica social aos costumes brasileiros.

Movidas pelo espírito carnavalesco, as chanchadas superaram suas limitações formais aprimorando-se nas paródias, reconhecendo que teriam de abandonar a forma impecável e valorizar o cotidiano (o não o eterno) e o riso (o não o sério), que deveriam gargalhar de si mesmas, para poder realizar filmes, em vez de simplesmente copiar o modelo estrangeiro.

As chanchadas não apenas copiavam o estilo dos musicais hollywoodianos, mas suas narrativas imprimiam um acento próprio aos filmes, ao parodiar, ironizar, debochar, satirizar as produções norte-americanas. A imitação e o pastiche também foram freqüentes, e as zonas entre essas formas e a paródia, o pastiche, a ironia, a sátira, a caricatura, por vezes se cruzam na chanchada.

O mimetismo presente nas chanchadas, apontado por Bernardet (1979), Vieira (1995) e Sérgio Augusto (189), com efeito, ocorre em relação aos cenários, aos trajes e à formula narrativa de mesclar o enredo com números musicais, mas a chanchada transcende à mera imitação por meio da paródia e da carnavalização próprias a grande parte dos filmes.

Essas formas são comuns ao gênero prosaico do discurso. Entre elas, a paródia foi bastante utilizada na literatura, no teatro leve, musical, em revistas, 
vaudevilles. La Belle Hélène, musica de Offenbach, tornou-se Abel-Helena e La filli de Madame Angôt virou $A$ filha de Maria Angu, em revistas de Artur Azevedo, dramaturgo brasileiro do teatro de revista.

Embora tenha se desenvolvido em outros países, em nenhum deles o gênero chanchada colocou tanto o "sotaque" nacional em seus filmes como nas comédias musicais brasileiras. Sergio Augusto (1989) nota que, se as nossas produções chanchadescas fossem comparadas às outras chanchadas (mexicana, argentina, cubana, portuguesa e italiana), que também procuravam transplantar o espírito carnavalesco - mesmo quando seus cantores entoavam tarantelas, árias de opereta, tangos, fados, chulas, mambos, boleros, congas e rumbas -, as comédias musiciais brasileiras têm a seu favor o próprio carnaval ao vivo, a “segunda vida do povo, baseado no princípio do riso", conforme lembra Bakhtin. (1997)

\subsubsection{NARRATIVA CLÁSSICA}

A narrativa chanchadesca segue o padrão linear da narrativa clássica norte-americana. Em nenhuma chanchada encontramos narrativas arrojadas, construídas apenas no plano visual como podemos observar no filme dirigido por Mário Peixoto e produzido pela Cinédia, Limite $(1931)^{57}$, que segue a tradição de “um cinema europeu proposto na década de 20 por Epstein, Dullac, Gance,

\footnotetext{
${ }^{57}$ Limite é considerado por estudiosos do cinema brasileiro, como Vieira (1987), um dos marcos da década de 30 e a melhor contribuição brasileira para a avant-garde internacional.
} 
Eisenstein ou mesmo Vertov", a qual propõe imagens que ganham sentido no ritmo dado pela montage (1987).

Nas chanchadas a montagem é linear, assim como a utilização de planos: a composição das cenas fílmicas tem como base planos médios para introduzir uma cena, planos e contra-planos americanos, para apresentar o diálogo entre as personagens, e planos gerais para os números musicais. Os primeiros planos são utilizados geralmente para destacar um cantor de sucesso das rádios, como Cauby Peixoto em com Água na boca (1956) ou Maysa, numa boate de O Camelô da Rua Larga (1958), Ivon Curi em Garotas e samba (1957), ou Doris Monteiro, numa cena romântica de canção em De Vento em Popa (1957).

Os primeiros planos também são utilizados com freqüência para dar ênfase a um objeto, como a cigarreira de Carnaval no Fogo (1949), que tem uma função na troca de identidade entre duas personagens, ou para destacar manchetes de jornais, aparelhos de rádio, televisão, entre outros elementos que têm uma função essencial para o desenrolar da narrativa.

Os movimentos de câmera resumem-se basicamente a abertura de plano através de zoom e a panorâmicas. Os travellings são raros e usados em cenas externas para acompanhar carros em movimento, como acontece na fuga de Horácio em Nem Sansão nem Dalila (1954) pelas ruas do Rio de Janeiro ou na 
externa em que Zé do Lino (Anselmo Duarte) passeia no centro de São Paulo em Absolutamente (1957).

\subsubsection{A ESTRUTURA DA NARRATIVA CHANCHADESCA}

Carlos Manga delimita a estrutura narrativa chanchadesca em quatro estágios: 1) mocinho e mocinha se metem em apuros; 2) cômico tenta proteger os dois; 3) vilão leva vantagem; 4) vilão perde vantagem e é vencido - o esquema só era alterado quando o mocinho, por força das circunstâncias, revelava-se um espertalhão. Esses estágios constituíam a fórmula geral das chanchadas (Sérgio Augusto, 1989).

As chanchadas, particularmente nos anos 50 , levavam às telas os segmentos sociais do mais diferentes matizes. Entre as personagens do gênero, além do vilão, há a presença de dois heróis: o herói-bom-moço (o tipo galã) e o (anti-)herói cômico (o tipo popular-malandro-palhaço), que se mete em trapalhadas, comete algumas contravenções, mas é “boa praça” e, no fim do enredo, ajuda o mocinho a resolver o problema armado pelo vilão ou a encontrar uma solução para a confusão na qual estão metidos. A heroína é a mocinha (geralmente namorada do herói-bom-moço). Há, ainda, as antiheroínas cômicas ou vilãs. 
Esses tipos foram interpretados por atores com tradição no circo, no teatro mambembe e de revista e no rádio, que guardavam grandes heranças populares, acrescentando muitas vezes passagens de suas vidas modestas e cheias de dificuldades aos papéis que encarnavam, a exemplo de Grande Otelo, Zé Trindade, Zezé Macedo, Dercy Gonçalves e Oscarito, o maior astro da Atlântida, que satirizou muitas personalidades famosas da época, como Getúlio Vargas, Rita Hayworth, Gary Cooper e Elvis Presley, e clássicos da literatura, como Hamlet e Romeu e Julieta. Na narrativa cômica da chanchada misturavamse circo-carnaval-teatro-rádio.

A recuperação das origens rurais, mais recorrente nos anos 40 , e o destaque dado aos valores ligados à amizade e à vizinhança são temas presentes na chanchada. Nas narrativas são mostrados, igualmente, o espanto das personagens diante de certos costumes urbanos, como a recusa ou não-adaptação à burocracia, a posição contrária à corrupção e a propensão para a assimilação de certos valores urbanos, sendo o mais expressivo o contato com a televisão, introduzida no país há poucos anos.

Para Chaia (1980), as personagens das chanchadas são agentes que não assimilaram a individualização da sociedade urbano-industrial, mas nem por isso são esmagados ou achatados pelas relações que se estabelecem no interior da sociedade. 


\subsubsection{DUPLA IDENTIDADE}

Quase todas as personagens da chanchada têm o seu duplo, a dupla identidade que se estabelece pela simples troca de papéis em decorrência de um equívoco ou uma confusão que será resolvida no fim da trama, ou ainda em razão de um sonho de melhoria de vida, ou por obra do destino mágico. Em Nem Sansão nem Dalila (1954), o barbeiro Horácio transforma-se em Sansão, um político populista, mas não se esquece da sua origem simples de barbeiro, nem das mazelas que assolam o Rio de Janeiro. Neste caso, a mudança não passa de um sonho e a personagem retorna à condição inicial. Outras vezes, as personagens alcançam um novo patamar social por obra da sorte.

A inversão de papéis entre as personagens ou a falsa identidade verificamse até nos títulos dos próprios título filmes, a exemplo de 0 falso detetive (1950). Situações em que ocorrem troca de identidade ou melhoramento da condição inicial das personagens são freqüentes nas chanchadas: em Com água na boca (1956), os palhaços circenses Carequinha (Carequinha) e Fred (Fred Villar) transformam-se em astros da televisão, junto com a desajeitada mocinha Marina (Anilza Leoni), que com perseverança e muita sorte torna-se garotapropaganda de TV. Em De Vento em Popa (1957), uma empregada doméstica tem opinião própria sobre a imprensa.

Na chanchada O homem do Sputnik (1959) o verdadeiro nome do colunista social Jacinto Pouchard (Cyll Farney) é Nelson, um profissional do jornalismo que 
almeja ser repórter investigativo. No decorrer da narrativa, Anastácio Fortuna (Oscarito), um simples homem da zona rural, transforma-se no assediado "homem do Sputnik" e passa a viver no mundo da high society, mas no fim prefere voltar à condição inicial. Em Carnaval Atlântida (1952), o erudito professor Xenofontes (Oscarito), especialista em história grega clássica travestese de Helena de Tróia para ensaiar os diálogos de uma cena do épico “Helena de Tróia”, filme que será engavetado e substituído por um musical carnavalesco.

Chaia (1980) assinala que a narrativa chanchadesca, geralmente, constituise de tema básico e é conduzida por uma personagem que tem um objetivo a ser realizado. Esse projeto termina sendo concretizado por obra do acaso, como num passe de mágica, e não devido a qualquer esforço pessoal ou habilidade específica.

A partir desse tema central, o filme desenvolve-se por meio de uma série de confusões e conflitos para, no final, tudo se resolver harmoniosamente, com o herói salvos e os vilões punidos. "Paralelamente à ação básica, desenvolve-se a ação do vilão, que procura se apossar ou se beneficiar do lance de sorte, e a ação do personagem-amigo, que ajuda a realização do objetivo colocado e também participa ativamente dos quiproquós” (Catani e Souza 1983, 72-73) 
Em Absolutamente Certo (1957), um gráfico recebe um prêmio num programa de televisão de perdas e ganhos e realiza seus sonhos: comprar uma cadeira de rodas para o pai e casar-se. Para Miguel Chaia (1980), na chanchada o “dinheiro é colocado como o artifício que, quando ao alcance dos personagens, permitirá a realização do objetivo ou a solução do conflito. Face a este artifício caracterizam-se os incluídos e os excluídos na sorte”. Em suma, a chanchada traduz o espírito do hedonismo consumista, no qual o dinheiro permeia as relações sociais em todos os níveis: no cotidiano, nos desejos, nos sonhos, no lazer.

\section{CAPITULO III - A MÍDIA NA DÉCADA DE 50}

\subsection{A MÍDIA RUMO À ORDEM MERCADOLÓGICA}

Na década de 50, multiplicaram-se no Brasil os empreendimentos culturais com perfil empresarial. A introdução da televisão na cidade de São Paulo (1950) e o dinamismo crescente na área publicitária, com a entrada das multinacionais (GM, Bayer, Ford, Colgate, Palmolive etc.) nas campanhas, marcaram o início da mercantilização da cultura. Como aponta Ortiz (2001), nos anos 50 o segmento publicitário desenvolveu-se em estreita relação com as matrizes americanas, que trouxeram para o Brasil as técnicas de vendas de produtos. 
Com efeito, esse cenário começou a se desenvolver a partir dos anos 40, quando se consolida o que os sociólogos denominam de sociedade urbanoindustrial, contexto histórico em que há a presença de diversas atividades associadas a uma cultura popular de massa no Brasil. Essa "sociedade de massa" incipiente era uma decorrência da modernização pela qual passava o país, particularmente após a Segunda Guerra Mundial.

Nesse período, o país foi marcado pelo crescimento da industrialização e da urbanização, pela transformação do sistema de estratificação social com a expansão da classe operária e das camadas médias, pela implementação da burocracia e dos novos modelos de controle gerencial, pelo crescimento populacional e desenvolvimento do setor terciário no lugar do setor agrário. É nesse contexto mais amplo que foram "redefinidos os antigos meios (imprensa, rádio e cinema) e direcionadas as técnicas como a televisão e o marketing" (Ortiz, 2001, p. 39).

Com efeito, os meios de comunicação expandiram-se com uma certa rapidez nas grandes cidades na década de 50 . No entanto, o processo de mercantilização da cultura foi atenuado pela impossibilidade de desenvolvimento econômico mais generalizado no país. Naqueles anos, a "indústria cultural” e a cultura popular de massa emergente ainda eram bastante incipientes, por essa razão não é possível aplicar à sociedade brasileira dos anos 50 o conceito de indústria cultural introduzido pelos frankfurtianos Adorno e Horkheimer. As 
empresas culturais existentes buscavam expandir suas bases materiais, mas os “obstáculos que se interpunham ao desenvolvimento do capitalismo brasileiro colocavam limites concretos para o crescimento de uma cultura popular de massa. Faltavam a elas um traço característico das indústrias da cultura, o caráter integrador" (Ortiz, 2001, p. 48).

O conceito frankfurtiano pressupõe que os indivíduos, no capitalismo avançado, encontram-se atomizados no mercado e, dessa forma, podem ser “agrupados" em torno de determinadas instituições. A concepção é de que a indústria cultural é autoritária porque integra as pessoas do alto, impondo uma forma de dominação que as "sintoniza" a um centro ao qual elas estariam “ligadas”, padronizando-as. Em suma, Adorno e Horkheimer entendem que os espaços individualizados na sociedade moderna são invadidos pela extensão das fronteiras da racionalidade capitalista e integrados em um único sistema. Nesse sentido, a idéia de um centro, onde se agrupam as instituições legítimas, é fundamental para que se possa falar de uma sociedade de massa no interior da qual operam as indústrias da cultura.

É inegável o mérito dos estudos desenvolvidos pela Escola de Frankfurt, particularmente, o conceito de indústria cultural. Entretanto, cabe questionarmos a concepção maniqueísta que circunscreve os meios de comunicação num processo de degradação cultural, massificante. Essa visão 
exclui a heterogeneidade própria às produções culturais e às relações entre os meios de comunicação.

O discurso fílmico das chanchadas, no qual cabem as ideologias das elites e das massas populares, reflete a cisão existente entre elite e povo no Brasil da década de 50. A idéia de cultura popular enquanto cultura "baixa”, em oposição à cultura “alta”, uma produção ideológica do século XVIII, ainda encontrava-se arraigada nas classes hegemônicas do país nos anos 50 .

Por outro lado, nesse período processa-se o fenômeno cunhado por García Canclini (1997) de hibridação cultural - a coexistência da cultura popular, erudita e de massa no contexto da sociedade urbana, deflagrada a partir da migração do campo para a cidade nas décadas de 30 e 40 -, que se faz presente nas películas chanchadescas. Enquanto gênero popular de cinema, a chanchada absorve essa hibridação, ao mesclar em seus enredos o culto, o popular e o massivo.

Para Martín-Barbero (1997), o popular está inserido no massivo porque faz parte do cotidiano dos cidadãos. Com o surgimento das massas urbanas, a noção de popular mudou de sujeito homogêneo (íntegro e resistente) ou mero produto de manipulação para uma justaposição conflitiva com o massivo, pois há a sobrevivência, no massivo, de matrizes culturais (populares) em conflito. 
O autor assinala que a relação intrínseca do massivo com o popular fica evidente na estética dos meios de comunicação, na qual prevalece "a narrativa do romance popular e do melodrama, a narrativa do exagero e do paradoxo, de paixão e emoção" (1997, p. 309-321).

A chanchada dos anos 50 insere-se nesse contexto, uma vez que as bilheterias da Atlântida, a maior produtora do gênero, chegaram a superar o número de ingressos vendidos de alguns filmes de Hollywood. A popularidade da chanchada a transforma em meio massivo e vice-versa. Ou seja, há a absorção da cultura popular pela chanchada e da cultura de massa pelo público/povo.

Martín-Barbero reconhece a predominância de um modelo hegemônico nos meios de comunicação de massa que não tolera as diferenças e que opera a dissolução. Mas por esses meios também passam brechas, uma vez que eles são feitos de contradições e neles se expressam demandas diversas.

A imbricação culto-popular-massivo evidencia-se na chanchada por meio do discurso de crítica social que o gênero produziu, particularmente nos anos 50. Ao transitar por variados universos, das tradições para o mundo moderno, do campo para a cidade, do Rio de Janeiro para o Reino de Gaza, da clandestinidade para a formalidade, os personagens das chanchadas espelhavam o estranhamento entre cultura popular e de elite presentes no Brasil daqueles anos. 
No Brasil dos anos 50, apesar do processo de centralização iniciado pela Revolução de 30 e fortalecido pelo Estado Novo, a sociedade brasileira ainda era fortemente marcada pelo localismo. Mesmo o rádio, o meio de comunicação mais popular no país, encontrava dificuldade de se expandir devido ao subdesenvolvimento da sociedade brasileira. Nos anos 50 , a rede de comunicação por rádio ainda não havia se desenvolvido suficientemente para cobrir o território nacional; uma parcela considerável da população ${ }^{58}$ era excluída da radiodifusão. Um exemplo é o número de aparelhos de rádio, que salta de 2,5 milhões em 1952 para 4,7 milhões em 1962.

Apesar do subdesenvolvimento brasileiro, novos empreendimentos surgiram no início da década de 50 nas principais capitais do país, como os jornais Tribuna da Imprensa (1949) e Última Hora (1951), que introduzem novas técnicas de apresentação gráfica e inovações na cobertura jornalística. Nessa época, o Diário Carioca inovou no uso do lead (abertura de texto jornalístico) e torna-se o primeiro a empregar uma equipe de copidesque em sua redação. 0 Jornal do Brasil é totalmente reformulado, fato que tem grande impacto sobre as transformações subseqüentes na imprensa brasileira.

Essas mudanças surgiram, em parte, sob a influência da imprensa norteamericana. Alguns jornalistas que viveram nos Estados Unidos durante os anos 40, como Pompeu de Souza, Danton Jobim e Samuel Wainer, levaram sua experiência para o Diário Carioca e para o Última Hora, a partir da década de 50. No fim dos

\footnotetext{
${ }^{58} \mathrm{Na}$ década de 50 , o Brasil possuía, em média, 80 milhões de habitantes.
} 
anos 50, Alberto Dines introduziu novas idéias no Jornal do Brasil, como resultado de sua passagem pelo Los Angeles Times" (Abreu, 1996).

Foi assim que, na década de 50, a imprensa brasileira começou a se distanciar de uma de suas tradições: o jornalismo de combate, de crítica, de doutrina e de opinião. Essa forma de jornalismo convivia com o jornal popular, que tinha como características o grande espaço para os fait divers (pequenas notícias diárias), para a crônica e para a publicação de folhetins. A atualidade política não estava ausente, mas era apresentada com um texto pouco objetivo.

0 jornalismo de opinião, de forte influência francesa e dominante desde os primórdios da imprensa brasileira até a década de 60 , foi gradualmente substituído pelo modelo norte-americano, que privilegia a informação e a notícia e separa o comentário pessoal da transmissão objetiva e impessoal da informação.

O colunismo social também começou a se difundir nos jornais nos anos 50 . O colunista Ibrahim Sued foi o exemplar máximo desse gênero naquele período, com seu estilo próprio de inventar termos que entraram na moda, como champanhota, niver, su, ademã, de leve. Profissionais como ele e outros foram encarnados por personagens chanchadescas, a exemplo de Jacinto Pouchard (Cyll Farney), de O homem do Sputnik (1959). 
Ao longo dos anos 50 a imprensa diária passou por uma série de reestruturações: muitos jornais viram-se obrigados a reduzir seus cadernos especiais, enquanto outros, ao contrário, ampliaram sua área de atuação. 0 Estado de São Paulo, em 1953, e o Jornal do Brasil, em 1956, lançaram seus suplementos literários, editados aos sábados e domingos.

Para Sodré (1999), esse fato indica que a literatura e a arte eram vistas como algo sem importância, uma vez que eram destinadas simplesmente ao “lazer, à pausa, à ociosidade, coisa domingueira, aos dias em que, com a trégua no trabalho, é possível cuidar de alguma coisa sem importância, gratuita, fácil e vazia $[\ldots] ”(1999,85)$.

Eram nesses suplementos que os jornalistas ou "críticos de cinema" escreviam sobre a chanchada. Na década de 50, começaram a aparecer as publicações especializadas em cinema. Mas havia poucas revistas especializadas no assunto. E as únicas que alcançavam todo o país eram O Cruzeiro, fundada em 1928, e Manchete, lançada em 1952. O Cruzeiro, do grupo Diários Associados e que também tinha uma versão em espanhol, foi uma das revistas mais vendidas na América Latina e a maior do Brasil, chegando a alcançar uma tiragem de 720 mil exemplares com a cobertura do suicídio de Getúlio Vargas, em agosto de 1954.

Para termos uma noção de como os cadernos dedicados à cultura e variedades eram poucos, somente em 1958 começou a circular a "Ilustrada", da 
Folha de S.Paulo, que já fazia cobertura de assuntos culturais desde a sua fundação, em 1921, mas ainda não havia criado um caderno específico para esses temas.

De qualquer forma, nos anos 50 houve uma expansão do mercado de publicações, com a ampliação do número de jornais, revistas e livros, como descreve Ortiz:

São vários os indicadores que demonstram o crescimento deste setor: tiragem, importação de papel, e, a partir de 1947, implantação de grupos nacionais (Klabin) na produção de papel. Um exemplo é a tiragem da revista $O$ Cruzeiro, que em 1948 é de 300 mil exemplares, atingindo, quatro anos depois, o número de 550 mil. Paralelamente ao sucesso das radionovelas surgem as revistas de fotonovelas (Grande Hotel, 1951; Capricho, 1952) que, no princípio, veiculavam estórias idealizadas pela matriz italiana [...] (2001, 4243).

Até a década de 50 , os escritores brasileiros tinham enorme prestígio. Eles eram, segundo o escritor Ledo Ivo, protagonistas privilegiados da cena cultural, eram colaboradores dos suplementos literários dos anos 50 e podiam ser incluídos entre os chamados intelectuais criativos e distribuidores da cultura (Abreu, 1996).

Naquele período, havia uma predominância do intelectual escritor, poeta, cronista, ensaísta, crítico e historiador. A presença marcante desse tipo de intelectual está ligada ao fato de que os suplementos voltavam-se quase exclusivamente para a literatura, a história, a arte, a música, o cinema e o 
teatro, em detrimento da política e da economia. Ao lado do intelectual escritor, colaboravam nos suplementos o intelectual jornalista.

Em razão dessa proximidade do intelectual escritor e por estar atrelado a grandes grupos empresariais, o jornalista desfrutava de grande prestígio nos anos 50, tanto que muitos cineastas eram jornalistas ou vice-versa. A nata da crítica cinematográfica, de um lado a intelectualidade que defendia o cinema popular ligado às tradições e aos costumes do povo brasileiro, de outro o pensamento cosmopolita e dominante da Vera Cruz, passava pela imprensa. Os diretores e atores das chanchadas, do ponto de vista dessa elite intelectual, não eram considerados agentes da cultura formadores de opinião.

Nos anos 50, os suplementos literários não eram catalisadores de um discurso ideológico e político de esquerda, nem dos debates travados por universitários sobre o processo de desenvolvimento do país. Os debates sobre o futuro do país eram promovidos pelas vanguardas culturais e artísticas, por meio da divulgação do cinema crítico e de seus manifestos, do teatro engajado, da poesia concretista, das artes plásticas, da música etc. (Abreu, 1996).

Uma nova configuração foi-se impondo à imprensa e à estrutura produtiva do país durante a década de 50 . A substituição das importações determinou uma maior diversificação da atividade industrial. Com a introdução de novas técnicas 
de produção e administração, o Estado passou a assumir a função empresarial, voltando-se para a planificação do desenvolvimento.

Essas mudanças exigiram quadros com uma formação profissional técnicocientífica, alterando o grau de influência dos intelectuais no Brasil. Abreu assinala que

Da anterior formação essencialmente humanista-jurídica, começou a verificar-se a ascensão dos experts, dos 'tecnocratas', envolvidos na elaboração da política de desenvolvimento. Ao mesmo tempo, teve início o processo de formação de uma sociedade de consumo em que cada setor da cultura se desenvolveu de forma diferenciada. 0 teatro, o cinema, o rádio, a televisão, o disco, a publicidade, as editoras foram se estruturando como indústria de massa ao longo dessa década para finalmente atingir, nas décadas seguintes, a configuração de uma indústria de bens culturais (1996, p. 16).

Por sua vez, a imprensa, que até os anos 30-40 dependia dos favores do Estado, de pequenos anúncios populares ou domésticos e da publicidade das lojas comerciais, passou, na década de 50, a ser mais hegemônica, mais articulada com o poder empresarial e com o capitalismo que se expandiu em determinados setores com a industrialização do país.

Foram os anos da imprensa industrial, controlada por poucos grupos empresariais familiares brasileiros (Assis Chateaubriand, Roberto Marinho, Júlio de Mesquita Filho, Paulo Bittencourt, Nascimento Brito) e por agências de notícias internacionais. Período em que o jornalista é tido enquanto sujeito “intelectual” não mais em função da tradição literária da imprensa, mas em 
decorrência dos novos papéis que assume como profissional: como técnico da escrita, capaz de escrever sobre diversos assuntos, ou expert em determinados temas.

A produção intelectual na década de 50 foi profundamente marcada pelo debate de idéias políticas, pela ideologia do anti-comunismo (o PCB, Partido Comunista Brasileiro, permaneceu na ilegalidade durante toda a década), pela elaboração de projetos de desenvolvimento e pela ideologia nacionaldesenvolvimentista. Trata-se de um período de concretização de projetos elaborados durante a Segunda Guerra e o pós-Guerra, de realizações nos campos político, econômico, social e cultural. Naqueles anos, houve o restabelecimento do regime democrático, o que evidentemente permitiu a livre expressão de idéias e a explosão da criatividade em todas as áreas do conhecimento.

A efervescência cultural verificada na década de 60 construiu seus alicerces nos anos 50. Foram anos em que o engenheiro Lúcio Costa e o arquiteto Oscar Niemeyer levaram a cabo, em Brasília, suas idéias revolucionárias no campo da arquitetura urbanística. Época em que o Cinema Novo ensaiou seus primeiros passos inspirado no neo-realismo italiano do pós-Guerra, que produziu obras como Roma, Cidade Aberta (1945), de Roberto Rossellini, e Ladrões de Bicicleta (1948), o filme-manifesto desse movimento, de Vittorio de Sica.

Nos anos 50, o teatro brasileiro renovou-se ao adotar a temática social e política, lançando uma nova geração de atores, diretores e dramaturgos - no 
final da década, o Teatro Brasileiro de Comédia (TBC) reduz o número de espetáculos, enquanto o Teatro de Arena de São Paulo torna-se o grupo cênico a inovar a dramaturgia nacional com a encenação de Eles Não Usam Black-Tie, de Gianfrancesco Guarnieri, em 1958.

No campo da música, a bossa nova, ao incorporar o jazz e o bebop norteamericanos ao samba tradicional, constituiu-se na maior inovação da música brasileira. Em fevereiro de 1959, foi lançado o disco em 78 rpm contendo "Desafinado" (gravado em novembro do ano anterior) e "Hô-Ba-Lá-Lá" (gravado em fevereiro), de João Gilberto. Em março, foi lançado o primeiro álbum do músico, “Chega de Saudade”. De acordo com a Revista do Rádio, em 1959 “o assunto da moda no rádio, discos e TV, é João Gilberto. Todos são unânimes em dizer que estamos diante de um acontecimento totalmente novo na música popular” (Revista do Rádio, 1959).

Foi nesse contexto que o cinema, cuja base do modelo industrial havia sido lançada na década de 40, tornou-se "de fato um bem de consumo, em particular com a presença dos filmes americanos, que no pós-guerra dominaram o mercado cinematográfico” (Ortiz, 2001, p. 41).

Mesmo considerando a ingerência norte-americana no cinema brasileiro, foi durante os anos 50 que a chanchada viveu seu apogeu, tanto na relação com o público quanto no aprimoramento narrativo do gênero. Os filmes passam a 
distribuir de forma mais equilibrada os números musicais no enredo, isto é, ampliam os diálogos e encaixam a música como um complemento da história. Começam a despontar tramas mais elaboradas e mais críticas em relação ao contexto social. O recurso da paródia a filmes norte-americanos torna-se corrente, e os diretores que respondem por essas mudanças são José Carlos Burle, Carlos Manga e Watson Macedo, além do roteirista Victor Lima, todos na Atlântida.

Essa evolução narrativa da chanchada, antes de ser deliberada - com o intuito de ser reconhecida pela crítica especializada da imprensa -, esteve de fato associada às rápidas transformações pelas quais o Brasil passava: o surgimento da televisão em 1950, o fortalecimento da indústria nacional, a campanha pela nacionalização do petróleo, a transição da capital federal do Rio de Janeiro para Brasília ${ }^{59}$, a explosão dos meios massivos no país. A meta das produções chanchadescas era manter o esquema industrial da Atlântida, por esse motivo os diretores não podiam perder de foco do seu público-alvo: a grande massa assalariada.

Ortiz frisa que somente a partir da década de 40 se pode considerar seriamente a presença de uma série de atividades vinculadas a uma cultura popular de massa no Brasil. Nos anos 40, consolida-se o que os sociólogos

\footnotetext{
${ }^{59}$ A construção de Brasília foi iniciada em 1957.
} 
denominaram de sociedade urbano-industrial, que cria as condições sociohistóricas propícias para o despontar de uma "sociedade de massa" no Brasil.

A sociedade brasileira modernizou-se, em diferentes setores, após a Segunda Guerra Mundial. Os antigos meios (imprensa, rádio e cinema) e as técnicas como a televisão e o marketing são redefinidos dentro de um contexto mais amplo cujas mudanças estão associadas a "fenômenos como o crescimento da industrialização e da urbanização, a transformação do sistema de estratificação social com a expansão da classe operária e das camadas médias, o advento da burocracia e das novas formas de controle gerencial, o aumento populacional, o desenvolvimento do setor terciário em detrimento do setor agrário” (2001, p. 38-39).

\subsection{O RÁDIO SOB O CONTROLE DO ESTADO POPULISTA}

Em 1950, havia no Brasil 300 emissoras de rádio, concentradas nas capitais. Algumas, como a Rádio Nacional do Rio de Janeiro, tinham alcance em grande parte do território nacional. O traço mais característico do rádio naqueles anos foram os programas de auditório. Neles eram lançadas gravações de sucesso, realizavam-se sorteios, narravam-se vidas e apresentavam-se calouros, cantores amadores que, não raras vezes, tornaram-se grandes astros. 
O rádio também produziu estrelas do jornalismo no mundo e no Brasil. Eram comentaristas ouvidos com reverência por imensas multidões. Durante a Segunda Guerra Mundial (1939-1945), esses astros brilhavam como correspondentes na Europa conflagrada. O “Aqui, Londres”, da CBS, com Edward R. Murrow, por exemplo, marcou época (Costella, 1984). O primeiro jornal falado do rádio brasileiro entrou no ar na década de 40. Foi o “Grande Jornal Falado Tupi”, de São Paulo, da Rádio Tupi AM, que pertencia aos Diários e Emissoras Associados, conglomerado fundado por Assis Chateaubriand. Em 1941, foi criado o noticiário mais importante do rádio brasileiro: o “Repórter Esso"60.

No Brasil, o rádio desenvolveu-se na esteira da Era Vargas. A radiodifusão foi introduzida no país em 1922, e até 1935 as emissoras organizavam-se como sociedades e clubes cuja programação era de cunho erudito e lítero-musical, funcionando basicamente como meios não-comerciais. Havia poucos aparelhos e o ouvinte tinha que pagar uma taxa de contribuição para o Estado pelo uso das ondas. A mudança na legislação, em 1932, passou a permitir a publicidade no rádio, estipulando-a inicialmente em 10\% da programação diária. A partir da década de 30, o rádio tornou-se um veículo cada vez mais comercial, a ponto de alguns anunciantes, a maioria grupos estrangeiros, transformarem-se em verdadeiros produtores dos programas, como a Standart Propaganda e a Colgate Palmovile, que se encarregavam da contratação de atores, escritores e tradutores de radionovelas. Com o aumento do percentual de publicidade para

\footnotetext{
${ }^{60}$ Os programas levavam o nome dos patrocinadores, que controlavam o conteúdo e o perfil do que era transmitido.
} 
20\%, permitido pela legislação de 1952, acentuou-se o caráter comercial do rádio, que contribui para a expansão de uma cultura popular de massa (Ortiz, 2001).

Com o avanço da publicidade no rádio, despontaram os programas de auditórios, músicas variadas e especialmente a radionovela, introduzida no Brasil em 1941. Esta última em poucos anos constituiu-se no produto radiofônico por excelência, alcançando grande popularidade. A Rádio Nacional chegou a produzir, entre 1943 e 1945, 116 radionovelas, totalizando 2.985 capítulos $^{61}$. Em 1956, a radionovela compunha cerca de metade da programação da rádio, ou seja, eram transmitidas até 14 novelas por dia. No entanto, entre os anos 40 e 50, a rede de comunicação por rádio ainda era limitada em grande parte do território nacional, pois um número considerável da população não tinha acesso a esse meio. Em 1952, o Brasil possuía 2,5 milhões de aparelhos de rádio; esse volume saltou para 4,7 milhões em 1962.

A história do rádio no país está intrinsecamente associada à formação do Estado Novo e do nacionalismo. A Rádio Nacional, que se manteve durante vinte anos no ar no Rio de Janeiro (1936-1956), é o melhor exemplo de como a mídia rádio foi utilizada como veículo ideológico dos governos de Getúlio Vargas, do general Eurico Gaspar Dutra e de Juscelino Kubitschek, entre as décadas de 30 e 60. 
A idéia do Estado era utilizar os meios de comunicação de massa como instrumento de integração nacional, pois o Estado seria o espaço no interior do qual se realizaria a integração das partes da nação, como atesta Ortiz (2001). Com uma mercantilização da cultura incipiente, cabia ao Estado deter o poder e a vontade política para a transformação da sociedade brasileira. 0 rádio, principalmente, foi o instrumento ideológico de cunho fascista do Estado Novo. Entre os meios de comunicação de massa, foi o mais utilizado como veículo ideológico do governo de Getúlio Vargas.

Em 1937, sob o pretexto de que um suposto plano comunista (Plano Cohen) tomaria o poder por meio de luta armada, o presidente Getúlio Vargas anunciou no rádio a implementação no país do Estado Novo, que contava com o apoio dos setores mais conservadores. A nova ordem transmitida por radiodifusão caracterizava-se pelo autoritarismo, centralismo e corporativismo: extinguiu os partidos políticos, suspendeu as eleições livres, retirou o poder do Legislativo e do Judiciário e ampliou o mandato do presidente para seis anos.

O Estado Novo estabeleceu amplos poderes ao presidente, que passa a deter o controle de todo o país, inclusive dos governos estaduais, que perdem a autonomia. A nova Constituição, por ter-se baseado na constituição da Polônia, fica conhecida como "Polaca". Além da extinção dos partidos políticos, os sindicatos trabalhistas ficam subordinados a Vargas.

\footnotetext{
${ }^{61}$ As novelas difundidas no rádio abrangiam diversos gêneros, como religioso, policial, romântico.
} 
Em 1939, o governo Vargas criou o Departamento de Imprensa e Propaganda (DIP), órgão de censura e propaganda do Estado, que lança no mesmo ano $A$ hora do Brasil. O programa passa a ser transmitido diariamente das 19 horas às 20 horas $^{62}$ pela Rádio Nacional, difundindo os feitos do governo e os principais acontecimentos da vida nacional durante o Estado Novo. A censura atinge todos os meios de comunicação: teatro, cinema, rádio, jornais e revistas. O objetivo era alcançar todas as camadas populares, buscando interferir nos meios de grande alcance como o cinema e o rádio. Ortiz atesta que

a idéia para o cinema era transformá-lo, de 'simples meio de diversão', em aparelho pedagógico. A mesma preocupação orientava as metas do Estado em relação à radiodifusão, setor considerado como chave na promoção da educação e na transmissão da palavra oficial (2001, p. 51).

No entanto, o governo Vargas não avançou como pretendia na implementação dessa política de extremo controle dos meios de comunicação de massa. Havia uma contradição entre a intenção política e a realidade de mercado, uma vez que o governo incentivou o crescimento das emissoras comerciais. Até a própria Rádio Nacional, encampada pelo governo em 1940, “praticamente funcionava nos moldes de uma empresa privada. Seus programas (música popular, radioteatro, programas de auditório) em nada diferem dos outros levados ao ar pelas emissoras privadas" (Ortiz, 2001, p. 53).

\footnotetext{
${ }^{62}$ A edição matutina de A hora do Brasil foi lançada em 1957, no segundo ano do governo de Juscelino Kubitschek.
} 
Tomado como meio narrativo, o rádio é uma mídia da cultura moderna que se caracteriza pela difusão generalizada de bens simbólicos através de nova forma de interação social que atinge grandes audiências e supera distâncias espaço-temporais. A chanchada brasileira inspirou-se no rádio para criar seus enredos e até emprestou em seus filmes nomes de alguns programas, como Balança mas não cai, transmitido em 1948 pela Rádio Nacional. Em mais de vinte anos de existência, a Rádio Nacional foi líder de audiência, nas décadas de 40 e 50, a época de ouro do rádio brasileiro. Eram os anos dos programas de auditório, shows de calouros, canções de ídolos da época, radionovelas famosas, como Em busca da felicidade e $O$ direito de nascer, e das transmissões do popular Repórter Esso, com edições extraordinárias.

O sucesso crescente dos filmes da Atlântida nas décadas de 40 e 50, que chegavam ao grande público pela distribuição e exibição organizadas por Luís Severiano Ribeiro Jr., pouco a pouco acostumou os brasileiros a ver nas telas atores e atrizes com quem começavam a se identificar. Graças, principalmente, aos nomes já famosos do rádio, que possuíam fã-clubes espalhados pela cidade do Rio de Janeiro, com filiais também em outros estados, como os de Emilinha Borba, Ângela Maria e Marlene, que arrastavam multidões aos cinemas (Vieira, 1987). A mídia rádio exercia enorme influência no público e foi uma grande aliada da chanchada. Do rádio, o meio mais popular na época, a chanchada emprestou muitos dos astros e estrelas, explorando a popularidade desses ídolos, grande parte deles vindos do teatro de revista. Bernardet observa esse caráter mimético do cinema em relação ao rádio: 
A indústria cinematográfica criou suas estrelas, mas às vezes aproveita-se do estrelismo criado por outros veículos. É o que se verifica no Brasil, onde o Olimpo foi americano e os atores cinematográficos nunca chegaram a se consolidar. Mas [...] quando se lança Alô, Alô, Carnaval (1936) 'com todos os ases do rádio', quando se convida Emilinha Borba e um sem-fim de cantores para as chanchadas dos anos 50, granjeia-se para o cinema a fama desses artistas na música, no rádio [...] $(1980,74)$.

Merten lembra que "nas ondas do rádio, a chanchada estabeleceu um tipo de estrutura narrativa particular. Era como se o rádio ganhasse imagem. Tramas simples, humor e números musicais, a cargo dos cantores do rádio que eram os ídolos da época" (2001, p. c-3).

Em outras palavras, o maior ponto de convergência entre a chanchada e o rádio era o caráter popular de suas linguagens, destinado a alcançar um público cada vez maior. Assim, rádio e chanchada viviam em lua-de-mel desde os primórdios do gênero cinematográfico, inclusive os temas musicais lançados nas rádios eram usados nos filmes musicais carnavalescos e nas tramas da chanchada na mesma época para não perder a atualidade. Portanto, as radio-entrevistas eram favoráveis aos lançamentos dos filmes de chanchada.

Apesar de veicular programas norte-americanos - e com estes o american way of life -, o rádio estava diretamente ligado ao desenvolvimento e ao apogeu do gênero chanchada, por ter sido, ao mesmo tempo, o principal veículo de comunicação e integração nacional, nos anos 40 e 50. 


\subsubsection{A CHANCHADA E A BURGUESIA DO CINEMA PAULISTA}

A efervescência cinematográfica dos anos 50 criou suas bases na década de 40, com a fundação da Atlântida Cinematográfica, em 194. Além do gênero cômico-popular chanchada, produzido por companhias como Atlântida, Flama, Maristela, Cinedistri, Watson Macedo, entre outras empresas, nos anos 50, o cinema brasileiro realizou, entre o eixo Rio-São Paulo, diversos dramas, melodramas (capitaneados pela produtora paulista Vera Cruz), documentários e filmes de cunho histórico, lançando as bases do cinema novo inspirado no neorealismo italiano. A década de 50 é período no qual o cinema nacional mais produziu e distribuiu filmes, como atesta Ortiz:

Em 1941 é criada a Atlântida, que passa a produzir uma média de três chanchadas por ano, e em 1949 a Vera Cruz, que pretendia explorar um pólo cinematográfico em São Paulo. [...] Entre 1935 e 1949 tinham sido produzidos em São Paulo somente seis filmes. A criação desses novos centros de produção tem consequiência direta no mercado cinematográfico nacional; entre 1951 e 1955 foram realizados 27 filmes em média por ano" (2001: 42).

Assim como aconteceu com outros ciclos do cinema nacional, a Atlântida surgiu com um manifesto, o "Manifesto da Atlântida", uma espécie de carta de intenções escrita por Alinor Azevedo e Arnaldo de Farias. Entre outras coisas, afirmava: “[...] quem se propuser, fundado em seguras razões de capacidade, a contribuir para seu desenvolvimento industrial [do cinema brasileiro] ${ }^{63}$, sem dúvida estará fadado aos maiores êxitos”.

\footnotetext{
${ }^{63}$ Observação nossa.
} 
O manifesto da Atlântida foi, possivelmente, a primeira demonstração no meio cinematográfico brasileiro de consciência da necessidade de adequar a produção e a proposta de industrialização à realidade concreta do mercado. Essas intenções foram levadas a cabo pela produtora carioca, que, em vez de desperdiçar grandes somas com equipamentos e estúdios que não condiziam com a realidade econômica daquela época, construiu um estúdio bastante improvisado e procurou comprar equipamentos de segunda mão.

Nada podia ser mais quixotesco do que a fundação da empresa, em 1941. Com efeito, o cenário nacional e internacional não era nada favorável: a Segunda Guerra Mundial (1939-1945) dificultava o acesso a filmes virgens. O Estado Novo (1937-1945) reproduzia o espírito nazi-fascista, com censores cerceando a liberdade de imprensa e de expressão. No cinema, o mercado exibidor brasileiro era território de Hollywood. A Sonofilmes fora devorada por um incêndio. A Brasil Vita Filmes estava no quinto ano de filmagem da Inconfidência Mineira (um desastre). E a Cinédia só saldaria parte de suas dívidas alugando seus estúdios para Orson Welles rodar It's All True.

A Companhia Cinematográfica Vera Cruz (1949-1954), criada em 1949 por Franco Zampari, em São Paulo, também se propôs a se adaptar à realidade de mercado, mas, como assinala Bernardet (1979), a busca do universalismo na linguagem cinematográfica nacional tinha a função de "envernizar a burguesia 
periférica" que produzia filmes no Brasil, tornando-os mais dignos da autoimagem dessa burguesia que buscava se equiparar à burguesia dominante. A função desse grupo, observa o autor, era "superar magicamente tanto a precariedade inconfessável da realidade social brasileira como a precariedade cinematográfica” (1979, p. 77).

Os filmes do mercado interno que realmente se comercializavam e lucravam, antes, durante e depois da Vera Cruz eram as chanchadas, que não tinham o padrão internacional apregoado pela companhia paulista. Os orçamentos dos filmes chanchadescos eram muito baixos e fechados, ao contrário das produções Vera Cruz

A Vera Cruz era a “fábrica dos sonhos”, como assinala Galvão (1981), que descreve como a burguesia paulista entendia a chanchada:

\begin{abstract}
A sensibilidade burguesa, no entanto, repugnava na chanchada aquilo que ela tinha de mais aparente: a produção rápida e descuidada, alguns cômicos careteiros, o humor chulo, a improvisação, a pobreza de cenografia e indumentária, todas as decorrências do baixo orçamento. 0 que repelia, fundamentalmente, era a chanchada enquanto tipo de espetáculo, exatamente como o teatro ligeiro da época, e muito parecida com ele. Sobretudo como tipo de espetáculo, porque é pouco provável que as pessoas tivessem alguma noção do que representava a chanchada em termos de produção (GALVÃO, 1981, p. 84).
\end{abstract}

A Vera Cruz surge em um contexto econômico-cultural em que uma nova burguesia urbana paulista está empenhada em superar sua vocação provinciana, fomentando um sistema de produção cultural em sintonia com o crescimento 
industrial da cidade. Enquanto o Rio de Janeiro era a capital política, São Paulo configura-se nitidamente como a construção, avessa aos velhos cenários e aos velhos costumes do Brasil oitocentista e rural. Em consonância com o projeto de construção da modernidade paulista pelas suas elites intelectuais e com sua emergente burguesia industrial está o nascimento de instituições culturais - o Teatro Brasileiro de Comédia (TBC), o Museu de Arte Moderna (MAM) e a Cia. Cinematográfica Vera Cruz -, que materializam essa concepção de cultura cosmopolita e urbana que correspondia à representação da sociedade paulistana.

Para os críticos que preteriam a chanchada, a Vera Cruz era a promessa de um novo cinema nacional, pois inaugurava uma nova fase na cinematografia brasileira: a produção de um cinema “sério" em oposição a um cinema “burlesco”, “carnavalizado”, realizado pela Atlântida.

Ao contrário, a Vera Cruz deveria seguir o esquematismo industrial de Hollywood. A seriedade era expressa por meio da qualidade técnica e narrativa de seus filmes, que correspondiam ao ideal "estético-cultural hegemônico da burguesia industrial paulista". Afinal, a Vera Cruz era moderna e equipada com as últimas novidades tecnológicas, possuía um "star-system" nos moldes de Hollywood e colaboradores estrangeiros experientes.

Mas ao mesmo tempo que pretendia se firmar no mercado como um cinema industrial, foram poucos os sucessos de bilheteria da Vera Cruz. Na tentativa de atrair público, a produtora paulista contrata o popular Amácio Mazzaroppi, que 
estréia em 1951 seu primeiro sucesso no cinema, Sai da Frente, encarnando um caipira urbano. No ano seguinte, a Vera Cruz lança Mazzaroppi em Nadando em Dinheiro, porém o público rejeita a troca de papel de caipira pobre pelo de milionário. Em Candinho (1953), quando volta a representar o caipira, o sucesso é grande, mas a Vera Cruz já se encontra financeiramente abalada.

Outra grande diferença entre a Vera Cruz e a Atlântida: enquanto a produtora carioca se manteve por vinte anos no mercado e sua história se confunde com o próprio gênero chanchada - apesar de parodiar Hollywood construiu um cinema com forte identidade nacional -, as produções da Vera Cruz, boa parte delas baseadas em melodramas pequeno-burgueses, estilizavam a realidade brasileira em um modelo estrangeiro. Resultado: não sobreviveu ao gosto popular e fechou as portas em 1953, quatro anos após sua fundação. Os maiores problemas então enfrentados foram a lentidão da comercialização dos filmes e o desinteresse das distribuidoras norte-americanas em patrocinar a produção nacional.

A Atlântida, por reconhecer que não tinha condições de competir com as superproduções de Hollywood, preferia parodiá-las, em vez de “apenas copiálas" como tentaram fazer, em certa medida - especialmente no que se refere à 
estética adotada na narrativa e no décor (decoração de cena; cenário) -, os filmes da Vera Cruz. ${ }^{64}$

A chanchada Carnaval Atlântida, dirigida por José Carlos Burle em 1952, é um dos melhores exemplos dessa postura crítica sobre si mesma, de saber qual é o seu lugar no mercado. O filme é uma paródia sobre a própria chanchada, mostrando-a como uma opção em um país onde a superprodução é inviável. A paródia surge, então, como uma resposta do cinema colonizado, subdesenvolvido, por meio do gênero chanchada, ao cinema hegemônico norteamericano.

Assiste-se ao filme dentro do filme: o diretor Cecílio B. de Milho (uma paródia a Cecil B. de Mille) tem a intenção de filmar o épico “Helena de Tróia no Brasil", tema logo abandonado ao reconhecer que o cinema nacional não comporta temas sérios, ou seja, realizar superproduções nos moldes norteamericanos, com muitos extras e cenários grandiosos. Assim, a história de Helena de Tróia é substituída por um filme de carnaval, e o especialista em história grega, professor Xenofontes (Oscarito), contratado como consultor de costumes do filme original, abandona seus livros e se transforma num debochado carnavalesco (CATANI e SOUZA 1983, 84-85).

\footnotetext{
${ }^{64}$ A Vera Cruz renega a chanchada, contrata técnicos estrangeiros e ambiciona produções mais aprimoradas, como "Floradas na Serra", do italiano Luciano Salce, "Tico-tico no Fubá", de Adolfo Celli, e "O Canto do Mar", de Alberto Cavalcanti.
} 
A Atlântida Cinematográfica foi a mais antiga e a maior produtora de chanchadas. A empresa manteve-se mais de vinte anos produzindo nesse período 64 filmes (62 ficções e dois documentários). As outras companhias, como a Cinédia e a Brasil Vita Filmes, viviam mergulhadas em repetidos ciclos de melhora e piora nas suas produções.

No início dos anos 60, o gênero chanchada entrou em crise e, com ele, a Atlântida, que encerrou a produção de filmes chanchadescos em 1962. Em parte, este fato se deve ao surgimento da televisão em 1950, que, ao longo da década, “roubou” anunciantes do rádio e, aos poucos, as platéias da chanchada.

Ainda assim, a respeito do fim das produções chanchadescas, particularmente da Atlântida, cabe salientar que, em âmbito mundial, a televisão foi a maior responsável pela evasão do público dos cinemas a partir de meados dos anos 50, como atesta Bernardet (1980, 87-88):

0 público quase indiferenciado que se verificou nas décadas de 20 , 30 e 40 modifica-se profundamente a partir de cerca de 1950. Surge a TV, que logo se torna o veículo de massa por excelência e destrona o cinema. Atribui-se à TV sobretudo, mas também ao desenvolvimento de outras formas de lazer, uma evasão de público que em muitos países atinge índices fantásticos. Para só citar os Estados Unidos, passa-se de 21.000 salas de exibição e 90 milhões de espectadores em 1945 para 14.000 e 45 milhões de espectadores em 1955, e no mesmo período passa-se de 30.000 receptores para 46 milhões. 
No fim da década de 50 , os gêneros comédias ligeiras e musicais começaram a envelhecer em função da repetição exagerada de uma mesma fórmula que já soava ultrapassada. Entre os diversos motivos que contribuíram para o fim da chanchada destaca-se o novo cenário político do Brasil, com a transferência da capital federal do Rio de Janeiro para Brasília, que influenciou o imaginário popular. Com a consciência política mais acentuada entre os estudantes e a população das grandes cidades, as gagues da chanchada soavam anacrônicas.

A televisão tornou-se muito mais popular no fim dos anos 50 . Com um cinema nas telas de contexto social e político nunca antes vistos - o Cinema Novo, influenciado pelo neorealismo italiano ainda em meados dos anos 50 -, todo o esquema de produção sobre o qual se sustentava a Atlântida começou a ruir, e os artistas cômicos, diretores e equipe técnica não tiveram outra saída senão assumir cargos nas emissoras de televisão, no início a rede Tupi.

Segundo Sérgio Augusto (1989), o desgaste sofrido pelas chanchadas está relacionado com a desumanização das nossas metrópoles, marcadamente a partir do surto desenvolvimentista de JK, na segunda metade dos anos 50 .

Para Rudolf Piper (1977), houve um afrouxamento progressivo do espírito festivo e carnavalesco do brasileiro, em particular do carioca. À medida que as tendências cosmopolitas foram aprofundando o processo de urbanização - e 
desumanização - de grandes camadas de nosso povo, perdiam-se os últimos vestígios de inocência e autenticidade, nos quais estavam assentadas as bases dessas comédias.

\subsection{A MÍDIA IMPRESSA E A ESTIGMATIZAÇÃO DA CHANCHADA}

A estigmatização da chanchada pela imprensa iniciou-se bem antes de o gênero ser produzido no Brasil nos moldes industriais pela Atlântida Cinematográfica (1941-1962), a maior produtora chanchadesca. O que se convencionou chamar de chanchada no Brasil, na sua origem, eram comédias cujos enredos serviam apenas como pano de fundo para apresentar números musicais baseados no sucesso dos cantores do rádio e nas marchinhas de Carnaval.

As chanchadas derivaram dos filmes musicais carnavalescos, que por sua vez foram influenciados pelos filmes-revista e pelo teatro de revista. A narrativa chanchadesca é uma síntese de toda uma tradição que vem primeiro do teatro de costumes, "espetáculos que procuravam conciliar o vaudeville (parisiense) e a opereta (italiana), numa alquimia que, sob a designação de teatro de revista, conheceu um século de consagração praticamente ininterrupta”65 (Sérgio Augusto, 1989, p. 26).

\footnotetext{
${ }^{65}$ O período de tempo aludido vai da segunda metade do século 19 ao final dos anos 50 do século
} 20 [nota nossa). 
Essa herança do teatro de revista conferiu à chanchada, desde o seu nascimento, o estigma pela imprensa de subproduto cultural, uma vez que o teatro de costumes também foi marcado negativamente pela crítica desde a segunda metade do século XIX. Segundo Sérgio Augusto, o dramaturgo Arthur Azevedo, um dos maiores revisteiros daquele período, foi acusado pela imprensa da época de "precipitar a decadência do teatro nacional, ao aceder sem resistências às exigências do público" (1989, p. 25-26). Contudo, o espectador médio daquele tempo correspondia fielmente às paródias das comédias de costumes, lançadas a cada ano para concorrer com o vaudeville parisiense e a opereta italiana.

O teatro de revista, que substituiu o circo no espaço urbano, inseriu no lugar dos adestradores de feras, dos malabaristas, das dançarinas de picadeiro, dos palhaços, “[...] políticos corruptos, agiotas implacáveis, malandros cativantes, casais românticos e jornalistas matreiros", que eram destaque nas montagens junto com clones da cena política nacional. Na revista $O$ Rio de Janeiro de 1877, de Arthur Azevedo e Lino de Assunção, a personagem política uma paródia ao general Osório -, "sofria o diabo nas mãos de repórteres sedentos de notícias frescas sobre uma viagem dele ao sul do país" (Sérgio Augusto, 1989, p. 26).

O nome chanchada, conforme descrevem os estudiosos do gênero cinematográfico, deve ter sido utilizado na Argentina antes de chegar ao Brasil. 
Do espanhol, sua etimologia significa porcaria, peça teatral sem valor, destinada apenas a produzir gargalhadas, aproximando-se de “chancho", que significa porco ou sujo. É um termo também derivado da palavra italiana “cianciata", que, segundo o Grande Dizionario della Lengua Italiana, significa "um discurso sem sentido, uma espécie de arremedo vulgar, argumento falso”.

Sérgio Augusto lembra que a cumplicidade do cinema brasileiro com o público doméstico consolidou-se à revelia da mídia impressa, que veiculava artigos nada favoráveis às chanchadas. Por esse motivo não surpreende que "o seu apelido tenha saído das páginas dos jornais e das revistas como um estigma, [...] para designar um tipo específico de comédia, que também floresceu em Portugal, no México, na Argentina, em Cuba e na Itália” (1989, 16-17).

Talvez por não ter sido legitimada pelo gosto estrangeiro e por conter um apelo popular que incomodou parte da elite intelectual particularmente nos anos 40 e 50, o nome chanchada mantenha até hoje uma conotação pejorativa. Segundo definição do Dicionário Aurélio, chanchada, substantivo feminino brasileiro, quer dizer "porcaria" (1. peça ou filme sem valor, em que predominam os recursos cediços, as graças vulgares ou a pornografia. 2. qualquer espetáculo de pouco ou nenhum valor). O Dicionário Houaiss amplia um pouco a noção de chanchada:

[...] 1. Teatro espetáculo popularesco de baixa qualidade conceptual, formal e cultural, geralmente mesclando música e humor. 2. Cine TV espetáculo ou filme em que predomina um humor 
ingênuo, burlesco, de caráter popular. 3. Cine TV pejorativo filme cinematográfico ou programa televisivo de baixa ou má qualidade. 4. por extensão pejorativo comportamento ou providência carente de seriedade (a vida dela foi uma chanchada) (essas medidas do governo são uma chanchada) ETM orig. contrv. segundo nasc. do plat. Chanchada 'porcaria', p. ext., 'peça de pouco valor', destinada apenas a fazer rir. JM der. de um it. Cianciata (Houaiss, 2001).

Stam (2000) observa que o estigma ao qual vem sendo submetida a chanchada ao longo dos anos, no contexto social, provém do preconceito, da idéia incrustada de cisão entre cultura alta e baixa:

As paródias populares burlescas tipo chanchada têm sido objeto de uma série de preconceitos estratificados: em relação à comédia, como forma 'inferior' (preconceito que encontramos pelo menos desde Aristóteles), em relação à intertextualidade explícita (considerada derivativa e parasitária), em relação a trocadilhos e jogos de palavras (proverbialmente considerados como 'a forma mais baixa de humor'), em relação a palhaçadas físicas e pancadarias (consideradas grosseiras e vulgares) e finalmente em relação ao público, popular de classe baixa. Esses preconceitos têm em comum a noção de alto/baixo, superior/inferior [...].

As críticas às produções chanchadescas eram freqüentes em revistas especializadas, a exemplo de $A$ cena muda, uma das mais importantes nos anos 50. Em 1952, o crítico Salvyano Cavalcanti de Paiva escreveu artigo na revista intitulado "O cômico no cinema brasileiro", no qual afirma que "fazemos comédia", porém “o pior tipo de comédia", definindo a chanchada como um "disparate vulgar combinado a um pouco de sexo e frases de duplo sentido [...], influência do baixo teatro, da burleta e do radiologismo mais ruim" (Sérgio Augusto, 1989, p. 24). 
No livro Revisão crítica do cinema brasileiro (1963), uma espécie de manifesto que contém a maior parte das palavras de ordem política e cultural do cinema novo, o jornalista e cineasta Glauber Rocha narra que a primeira tática política do cinema novo, em 1962, era destronar a chanchada; a grande luta do cinenovistas era contra a chanchada: “[...] tudo que não era chanchada passava a ser 'cinema novo' para derrubar a chanchada”. Mais tarde reviu sua opinião, chegando a preconizar no livro Revolução do cinema novo (1981) "uma recuperação de formas nacional-populares como a chanchada”. Entretanto, Rocha classificou-a de "vulgar", de "câncer reformista do subdesenvolvimento", de “musicais alienantes" (1981, p. 285).

Frases como "mais um abacaxi nacional!” ou “descemos a nível de cloaca” eram comuns entre os críticos a cada lançamento de uma chanchada. Apesar dos preconceitos, com

seu humor quase sempre ingênuo, às vezes malicioso e até picante, o filme musical carnavalesco impôs-se como um entretenimento de massa de singular expressividade. Nem sempre o chamaram de chanchada e, em sua forma larvar, ele se ressentiu das limitações formais do filme-revista. [...] Seu humor mais ingênuo encantava as crianças, seu humor mais malicioso divertia os adultos, e seus interlúdios românticos e musicais fechavam o círculo da sedução familiar" (Catani e Souza, 1983, p. 86; Sérgio Augusto, 1989, p. 1617).

Em Assim era a Atlântida (1975), documentário com antologia de vários filmes da produtora carioca, produzido em 1975, Carlos Manga, diretor de clássicos como De vento em popa (1957) e O Homem do Sputnik (1959), relembra 
quem estigmatizava a chanchada: "Os filmes musicais carnavalescos eram chamados de chanchada por alguns esnobes que gostavam de filmes estrangeiros $[\ldots] "$

A nata da crítica cinematográfica brasileira nos anos 50 - de um lado a intelectualidade que defendia o cinema popular ligado às tradições e aos costumes do povo (a exemplo dos filmes de Humberto Mauro), de outro o pensamento cosmopolita e dominante da Vera Cruz -, passava pela imprensa. Os diretores e atores das chanchadas, do ponto de vista dessa elite intelectual, não eram considerados agentes da cultura formadores de opinião.

Apesar do grande sucesso comercial, as chanchadas ressentiam-se da interferência negativa de jornais e revistas em relação à sua produção. Se o estigma imposto aos filmes chanchadescos por um lado não esmoreceu a maior produtora do gênero, a Atlântida Cinematográfica, por outra parte criou uma auto-imagem depreciativa entre os que estavam envolvidos com esse tipo de produção. Diretores e atores de chanchada assimilaram dos críticos "uma concepção renitentemente pejorativa da chanchada”. Até Carlos Manga, o mais bem-sucedido diretor de chanchadas, não as tolerava, conforme admitiu em inúmeras entrevistas. "A loucura do Manga era fazer uma fita dramática, mas não conseguia", declarou Oscarito em depoimento ao Museu da Imagem e do Som (MIS) do Rio de Janeiro, em 11 de setembro de 1968. 
Esse constrangimento confirma-se em 1977, quando a chanchada já não era tão estigmatizada pelos críticos. 0 ator Wilson Grey deixou os velhos companheiros e os revisionistas estarrecidos com a seguinte declaração ao semanário Pasquim:

Era constrangedor ir por esse Brasil afora vendo as fitas de Oscarito, Ankito, Grande Otelo. Em todas elas, eu, José Lewgoy, Wilson Viana, Catalano, participávamos. E era constrangedor porque fazíamos esse filme que não tinha nada a ver com a realidade brasileira, feitos única e exclusivamente para divertir. 0 sr. Luiz Severiano Ribeiro fazia esses filmes porque davam dinheiro. Eram filmes de baixo nível intelectual, não deixavam nenhuma mensagem, não retratavam nada da vida ou costume brasileiros [...] mas davam rios de dinheiro porque o índice de analfabetismo no Brasil, há alguns anos, era grande [...] A nossa chanchada nunca retratava o que era nosso [...] Nosso cinema não trazia nada para o povo (Sérgio Augusto, 1989, p. 29).

Para os críticos que preteriam a chanchada, a Companhia Cinematográfica Vera Cruz (1949-1954) configurava-se como a promessa de um novo cinema nacional, pois inaugurava uma nova fase na cinematografia brasileira: a produção de um cinema "sério", com grandes recursos técnicos. As chanchadas eram vistas pela elite cultural paulista como um cinema "burlesco", "vulgar", retrato do subdesenvolvimento do país. A Vera Cruz, ao contrário, deveria seguir o padrão de qualidade hollywoodiano. Além do aprimoramento técnico, a seriedade também se expressava na narrativa melodramática das películas produzidas pela produtora paulista. Mesmo quando a Vera Cruz realizou comédias populares com Amácio Mazzaroppi, a primazia técnica era motivo para o elogio da crítica. 
Nas relações históricas de poder hegemônico, a ideologia predominante da elite intelectual brasileira menosprezou o cinema popular que escapasse ao modelo pré-moldado de registro dos valores genuínos do homem e da terra. A chanchada, cuja narrativa pautava-se no princípio cômico-carnavalesco, não se enquadrava em nenhuma categoria estanque nos anos 40 e 50.

Foi este princípio carnavalesco que assegurou à chanchada uma relação saudável com o público, que enchia as salas de cinema para se reconhecer nas telas. O povo brasileiro ia ao cinema não para sonhar, mas para rir, rir de si mesmo e do Brasil - do estigma de ser do Terceiro Mundo ou, como se dizia naquela época, de ser "subdesenvolvido". A enorme aceitação popular do gênero cômico chanchada, como assinala Viany (1959), devia-se aos elementos tipicamente brasileiros presentes nos enredos dos filmes: carnaval, situações do cotidiano, o jeitinho brasileiro de ser.

Com efeito, o público se identificava com as chanchadas. 0 discurso da crítica não tinha grande ressonância entre a massa popular, até porque boa parte dela não era alfabetizada - na década de 50, o grande público praticamente não lia jornais e, quando os lia, interessava-se pelas páginas policiais ou manchetes políticas. Entre outros atributos, o filme atraía os não-letrados por não haver a necessidade de ler letreiros. Nesse sentido, a chanchada estabelecia uma relação de proximidade com o rádio, meio cuja linguagem sonora e lítero-musical era familiar ao público. 
A chanchada foi estigmatizada de subproduto cultural, particularmente pela mídia impressa e cinematográfica. O rádio serviu de inspiração para os filmes chanchadescos e a televisão, como mídia incipiente, herdou elementos da narrativa chanchadesca. O reconhecimento dessas produções como gênero cinematográfico popular, cujos enredos abarcam discursos de crítica social, só viria a se concretizar no final dos anos 70 e início da década de 80 , após revisões críticas promovidas por uma nova geração de teóricos de cinema.

O crítico Alex Viany foi pioneiro, em 1959, ao reconhecer na chanchada um tom popular voltado para o cotidiano, um reflexo das atitudes e modos de ser da gente brasileira. No entanto, a prática corrente entre os críticos na década de 50 era estigmatizar negativamente os filmes chanchadescos. A revista especializada em cinema $A$ cena muda afigura-se como uma das publicações que contribuíram para o estigma degradante dessas produções. Os filmes vistos pela crítica da revista eram cotados com notas de 1 a 5: Fraco (1), Regular (2), Bom (3), Muito Bom (4) e Ótimo (5). A chanchada Aí vem o barão (1951) nem chegou a receber a classificação 2 (Regular), nem ao menos pelo mérito de Oscarito ser o campeão de bilheteria no mercado cinematográfico brasileiro. 0 filme não foi recomendado "[...] a ninguém $[\ldots]$ ":

1 Depois de fazer 'A sombra da outra', um dos melhores filmes nacionais, os produtores 'entendidos' acharam que Watson Macedo devia prosseguir elaborando películas no estilo 'Carnaval no fogo', 'Segura esta mulher' e 'Aviso aos navegantes', que bateram recordes de bilheteria. Conclusão: 'Aí vem o barão' foi o pior de todos e o que 
mais rendeu na primeira semana de exibição. É isto porque Oscarito continua sendo o campeão de bilheteria no mercado brasileiro, fazendo frente aos maiores cartazes estrangeiros. Qualquer história serviria, e seria filmada de qualquer maneira. Assim foi. Resultado: um espetáculo para o público infantil, ou para adultos de mentalidade infantil, ou para os fãs de Oscarito, que adoram ver seus trejeitos sempre repetidos. [...] Não recomendamos a ninguém, mas temos certeza que os fãs de Oscarito e do cinema brasileiro irão de qualquer maneira. ${ }^{66}$

Em tom irônico e formato de editorial, pois raramente uma crítica era assinada em $A$ cena muda, outro artigo denigre os atores do cinema nacional ao comparar as cenas dramáticas dos filmes com uma chanchada:

\begin{abstract}
Astros Brasileiros
Não se pode contestar que o nosso cinema já possui astros de apreciável grandeza no firmamento artístico verde-amarelo. [...] 0 drama é o que mais estraga os nossos artistas, especialmente quanto às 'estrelas'. Raramente o 'suspense' dramático ajuda a platéia a sentir as emoções indispensáveis às cenas culminantes ou emotivas. Muitas vezes o público desaba em gargalhadas e galhofas quando todo mundo devia estar sofrendo com os artistas na tela. $\dot{E}$ que as seqüências dramáticas se convertem na mais ridícula chanchada ${ }^{67}$. Mas não desesperemos. Já temos um Lewgoy (José Lewgoy) e uma Tônia Carrero. Tenham fé em nossos cineastas. 0 cinema brasileiro vencerá $^{68}$.
\end{abstract}

Mais um artigo de $A$ cena muda, um editorial dedicado ao cinema nacional, destaca os erros e defeitos dos filmes brasileiros, desta vez criticando a maquiagem exagerada nas atrizes:

\footnotetext{
Cinema e Arte
}

Basta uma cena em que artistas não estejam bem, para deitar a perder o filme inteiro. 0 espectador é exigente, e a crítica ainda mais. Quando o filme é bom, ainda é possivel que se fechem os olhos a certos erros e defeitos; mas, como os nossos filmes

\footnotetext{
${ }^{66}$ Revista A cena Muda, 6 de dezembro de 1951.

${ }^{67}$ Grifo nosso.

${ }^{68}$ Revista A cena muda, 15 de agosto de 1952.
} 
raramente atingem o nível de bons ${ }^{69}$, é preciso toda cautela para que não haja cenas destoantes do bom gosto e da arte. Nosso cinema já progrediu muito, realmente; mas ainda possui defeitos lamentáveis. Um deles é a maquilagem, especialmente em se tratando de figuras femininas de primeira linha. Uns lábios mal pintados são de ridículos intolerável e provocam comentários desabonadores. Muitas vezes a artista se sai bem de suas interpretações; mas o baton ${ }^{70}$ estragou tudo. Um bonito palminho de cara não se destrói com um lambuzado de tinta. Vejam os leitores como está mal pintada a boca de Patrícia Lacerda encarnando o papel de Sônia em 'Com o diabo no corpo', direção de Mário de Rio. A maquilagem labial não deve apresentar reflexos diante dos refletores, como acontece na foto que ilustra esta página. [...] Nosso cinema precisa ir desbastando as arestas de suas insuficiências, de seus erros, sem o que muito dificilmente obteremos triunfos definitivos. [...]"71.

A respeito da reincidente crítica ao cinema nacional articulada por $A$ cena muda, Galvão assinala que a revista concebe o cinema brasileiro como um reflexo do subdesenvolvimento do país, apregoando que talvez a solução para o cinema nacional fosse simples: “[...] por que não empreendem os poderes públicos a construção de casas exibidoras exclusivamente para películas nacionais"? (1981, p. 44).

Com efeito, os recursos técnicos e artísticos-cenográficos das chanchadas daquela época eram bastante limitados, se comparados aos padrões de Hollywood. O fato é que a limitação legitimava o discurso de desvalorização imposto pelos críticos aos filmes nacionais. Eles não conseguiam ter uma visão

\footnotetext{
${ }^{69}$ Grifo do autor.

${ }^{70}$ Grifo do autor

${ }^{71}$ A revista A cena muda, 8 de agosto de 1952.
} 
mais abrangente da cadeia produtiva que envolvia realizar um filme, ainda que fosse uma chanchada.

Produzir uma chanchada exigia desde a contratação de atores, maquiadores, maquinistas, iluminadores, diretores, fotógrafos, cenógrafos, assistentes em diversas funções, até a distribuição dos filmes no mercado. Assim empenhava-se a Atlântida, a maior produtora do gênero, para se firmar como indústria do entretenimento nas décadas de 40 e 50, apesar dos baixos orçamentos empregados em relação às produções da Vera Cruz. Nos tempos áureos, a produtora paulista congregou em seus estúdios, em São Bernardo do Campo (SP), uma vasta equipe de diretores estrangeiros, alguns deles importados da Itália. De fato, a melhoria técnica no cinema nacional só viria a ser introduzida com a criação da Vera Cruz, em 1949.

Do ponto de vista do mercado, as “comédias musicais" eram produtos culturais para ser consumidos pelas massas assalariadas. No entanto, a partir da atribuição pejorativa de "chanchada", assumiram o perfil de produtos menores. No entanto, a Atlântida Cinematográfica foi fundada com a intenção de transformar o cinema brasileiro em uma grande indústria do entretenimento. Em seu estatuto consta claramente o objetivo de produzir melodramas, documentários, cinejornais, entre outros formatos. A predominância das chanchadas foi uma decorrência da grande aceitação desses filmes pelo mercado exibidor. 
O crítico de cinema Luiz Carlos Merten, que considera o gênero chanchadesco uma vertente polêmica do cinema, dado o estigma negativo que recebeu da elite intelectual durante anos, lembra que

\begin{abstract}
a chanchada, com raízes no humor radiofônico e na tradição do teatro de revistas, sempre dividiu os intelectuais. Já foi definida como "rádio com imagem". E muitas vezes foi desprezada por seu gosto pela paródia, especialmente de filmes americanos, o que seria sintoma de alienação cultural e dependência do produto estrangeiro. [...] (Merten, 2001).
\end{abstract}

Nesta pesquisa entendemos que o gênero chanchada dialogou com a mídia a partir da posição estigmatizada (o lugar do "outro") que seus filmes ocuparam no estabelishment cultural dos anos 50. Pressupomos que, deste posicionamento como formação discursiva, a chanchada criou um discurso crítico a respeito da imprensa, do rádio, da televisão e do cinema. No plano dialógico-discursivo apontado por Bakhtin, o discurso relaciona-se com outros discursos de que se apropria ou diante dos quais se posiciona (ou é posicionado) para que venha a produzir sentido.

Desse modo, adotamos a noção de estigma proposta por Elias e Scotson (2000), que discorrem sobre a relação entre estabelecidos e outsiders (estigmatizados), e por Stuart Hall (2003), que aborda a questão da construção social da identidade e diferença. 
A bem da verdade, o conceito de estigma é bastante difuso, mas se aplica perfeitamente às investigações dos discursos midiáticos, que criam estigmas negativos ou positivos em suas mediações das formas culturais. A figuração entre estabelecidos e outsiders é pertinente para analisar a questão do estigma chanchadesco por considerar a dinâmica das relações sociais, as diferentes situações que envolvem a aceitação ou a rejeição do grupo outsider.

Se por um lado o gênero chanchada foi estigmatizado negativamente, por outra parte assimilou uma contra-estigmatização positiva. A historicidade que abarca todo e qualquer enunciado revela esse processo de contra-estigmatização que envolve qualquer gênero artístico, até mesmo no momento em que é estigmatizado. Podemos citar, como exemplo, as chanchadas De vento em popa (1957) ou O homem do Sputnik (1959), umas das mais aceitas pelos críticos na época em que foram produzidas. Scotson observa que

\footnotetext{
A estigmatização, como um aspecto da relação entre estabelecidos e outsiders, associa-se muitas vezes a um tipo específico de fantasia coletiva criada pelo grupo estabelecido. Ela reflete e, ao mesmo tempo, justifica a aversão - o preconceito - que seus membros sentem perante os que compõem o grupo outsider. [...] Isso ilustra muito vividamente a operação e a função das crenças do establishment a respeito de seus grupos outsiders: o estigma social que seus membros atribuem ao grupo dos outsiders transforma-se, em sua imaginação, num estigma material - é coisificado (Elias e Scotson, 2000, p. 35)
}

Historicamente, os gêneros literários e teatrais influenciados pelos gêneros do sério-cômico e vinculados à cosmovisão carnavalesca, como a prosa, a ópera bufa e a vaudeville parisiense, foram estigmatizados como produtos da 
cultura baixa, do ponto de vista dos grupos que ocupavam o estabelishment social. O mesmo aconteceu com a chanchada, particularmente em meio à ebulição cultural dos anos 50 .

De acordo com Elias e Scotson (2000) o estigma social imposto pelo grupo mais poderoso ao menos poderoso penetra na auto-imagem deste último e chega a enfraquecê-lo e a desarmá-lo. A capacidade de estigmatizar diminui, ou até se inverte, quando um grupo deixa de estar em condições de manter seu monopólio das principais fontes de poder, isto é, quando o equilíbrio de poder é ameaçado. Entendemos que o estigma da chanchada como subproduto cinematográfico foi, em parte, uma construção discursiva da mídia impressa, uma vez que esse meio estava posicionado no centro de uma elite cultural brasileira que, nos anos 50, rejeitava a possibilidade de um cinema fora dos padrões hegemônicos de Hollywood.

O processo de contra-estigmatização, ou de construção de uma nova identidade social, articula-se bem com a definição de identidade de Stuart Hall (2003, p. 111), para quem "as identidades são construídas por meio da diferença e não fora dela. Isso implica o reconhecimento radicalmente perturbador de que é apenas por meio da relação com o outro, da relação com aquilo [...] que tem sido chamado de seu exterior constitutivo, que o significado 'positivo' de qualquer termo - e, assim, sua ‘identidade’ - pode ser construído”. 
Entretanto, o estigma, que caminha para onde for a coisa ou o sujeito estigmatizado, permanece no imaginário coletivo. Mesmo reconhecida pela crítica especializada, a chanchada continua sendo estigmatizada como um gênero cinematográfico inferior no cinema nacional.

\section{CAPÍTULO IV -O DIÁLOGO DA CHANCHADA COM A MÍDIA NOS ANOS 50}

Neste capítulo, empreendemos a análise do corpus nos níveis verbal, visual e sonoro, buscando apreender as vozes que permeiam, no discurso parodístico e discurso irônico, o diálogo da chanchada com a mídia.

A leitura dos narratemas "Votai em Sansão, um homem de ação" e "Cinema indígena" nesses níveis toma o enunciado em sua totalidade, considerando a participação de todos os elementos que se associam com os diálogos organizados numa determinada seqüência narrativa, mas não pretende esgotar outras possibilidades de leitura de sentidos que emanam desses textos.

\subsubsection{NEM SANSÃO NEM DALILA, O RÁDIO E A TELEVISÃO}

Narratema I - "Votai em Sansão, um homem de ação"

O narratema, bloco narrativo ou texto "Votai em Sansão, um homem de ação", de agora em diante denominado de T2 (texto 2), foi delimitado do 
enunciado Nem Sansão nem Dalila ${ }^{72}$ por se afigurar como o ponto-chave para a análise do diálogo da chanchada com a mídia rádio, diálogo que se materializa no discurso parodístico. Em T2 ressoa, nos três níveis do fluxo discursivo-narrativo (verbal, visual e sonoro), um discurso-outro que, materializado num interdiscurso ressignificado pela paródia, traz as marcas de pré-construídos que ecoam nos sentidos possíveis decorrentes de T2. Dito de outra forma, T2 apresenta-se como uma síntese da paródia realizada por Nem Sansão nem Dalila (1954) ao épico Sansão e Dalila (1951), de Cecil B. de Mille, aqui denominado de T1 (textofonte). É com base nesse texto primitivo que T2 também parodia o Estado getulista e a Rádio Nacional. Em T2, o foco narrativo volta-se principalmente para a interação da personagem Sansão/Horácio ${ }^{73} \mathrm{com}$ o rádio, o meio de comunicação de maior alcance popular entre as massas assalariadas nos anos

\footnotetext{
72 Sinopse: A chanchada Nem Sansão nem Dalila (1954) narra a história do barbeiro Horácio (Oscarito), que num "passe de mágica" transforma-se num poderoso político, em plena campanha eleitoral. Paródia a Sansão e Dalila (1951), superprodução bíblica do norte-americano Cecil B. de Mille, Nem Sansão nem Dalila é uma sátira ao governo populista de Getúlio Vargas e ao cotidiano urbano da Capital Federal, o Rio de Janeiro dos anos 50, onde imperam a inflação, o consumismo, o desemprego, entre outros problemas estruturais do país. A narrativa inicia-se com o físico Incógnitus Von Tempo apresentando à comunidade científica e à imprensa a sua grande invenção: a Máquina do Tempo. Simultaneamente, naquela mesma manhã, o barbeiro Horácio chega atrasado ao Salão Dalila e, atrapalhado, arranca a peruca do mal-encarado lutador Chico Sansão (Wilson Viana), enquanto o barbeava. Irado, o brutamontes persegue o barbeiro pelo salão, envolvendo outras personagens na briga. Horácio aproveita a confusão e foge num Jipe, dirigindo desgovernadamente pelas ruas do Rio de Janeiro, até perder o controle e bater numa parede. Na colisão, cai na Máquina do tempo do cientista Incógnitus e viaja no tempo, saltando do Rio de Janeiro em 1954 para o Reino de Gaza em 1.130 a.C. Nesse jogo de espaço-tempo entre passado e presente, as personagens do presente (1954) têm a sua correspondência em Gaza. Nessa terra, Horácio encontra o forte Sansão (Wilson Viana), com o qual troca $o$ isqueiro por uma peruca, adereço que the confere poderes descomunais, transformando-o no poderoso Sansão. Depois de mandos e desmandos em Gaza e de correr risco de vida, Sansão/Horário volta ao Rio de Janeiro, em 1954, onde percebe que tudo não passou de um sonho ou de um pesadelo.

${ }^{73}$ Ao assumir o poder em Gaza por via indireta, em razão da sua imbatível força, o poderoso Sansão/Horácio implementa uma série de medidas populistas no Reino de Gaza, a exemplo da alteração na legislação trabalhista, do tabelamento de preços de produtos e do lançamento de "invenções modernas" como o rádio, o telefone e a televisão. Neste bloco narrativo, o estadista Sansão/Horácio escuta a programação da Rádio Gazeteira, "a preferida dos ouvintes", e censura o conteúdo transmitido por não divulgar a sua campanha política.
} 
$50^{74}$, mas também encampa toda a rede significante, ou seja, os diversos circuitos narrativos do enunciado que se relacionam com o rádio e produzem sentidos no espaço-tempo diegético. A focalização na televisão é secundária no narratema, no plano da alusão, mas suficientemente expressiva para situá-la em relação ao rádio e ao contexto socio-histórico nos anos 50 .

Antes de iniciarmos a análise, apresentamos a seqüência verbal T2, recortada de Nem Sansão nem Dalila:

Miriam (assessora de gabinete): "Não achais, poderoso Sansão, que essas novas leis estão criando confusão?"

Sansão/Horácio: “He, he, he, deixa a confusão. O governo é isso mesmo. Pelo menos na minha terra é assim, he, he... Ah, deixa eu ouvir meu programa de rádio." (Sansão/Horácio levanta-se e liga o rádio)

Locutor (em off): "Patrocinado pelo leite de cabra Samur, o único legítimo, puro e sem água, vendido exclusivamente pelo bazar de Abdula, o único barateiro de Gaza... (entra jingle da marca: 'Para homem, mulher e brotinho não há nada melhor, leite de cabra, beeé, Samur é o melhor)... Não deixai de ir esta noite à boate Gazeli, o melhor espetáculo da cidade com as dançarinas núbias e os cancioneiros do Egito. Preços baratíssimos e uísque legítimo... Atenção! Atenção! A partir de amanhã, o tráfego na rua principal será feito em mão única, devendo os burros e camelos que demandem a zona norte passar..." (irritado, Sansão/Horácio desliga o rádio.)

Sansão/Horácio: "Esse cara fala de tudo, menos da minha propaganda política. Deixa ele comigo!"

Miriam: "Mas está tão bom!"

Sansão/Horácio: “Tá bom nada!" (Sansão/Horácio dirige-se à rádio)

Locutor (em off): “...E fica também estabelecido que os camelos só podem estacionar na praça Sansão (Sansão/Horácio entra no estúdio e senta-se ao lado do locutor). E agora, num patrocínio exclusivo do Bazar Zacarias, voltamos a apresentar..."

Sansão/Horácio (interrompe a locução pondo a mão no microfone e fala ao locutor): "Chega de anúncio! Você é pago para fazer a minha propaganda política!"

${ }_{74} \mathrm{Em} \mathrm{1952,} \mathrm{o} \mathrm{Brasil} \mathrm{possuía} \mathrm{2,5} \mathrm{milhões} \mathrm{de} \mathrm{aparelhos} \mathrm{de} \mathrm{rádio;} \mathrm{esse} \mathrm{volume} \mathrm{saltou} \mathrm{para} \mathrm{4,7}$ milhões em 1962. 
Locutor: "Perdão, mestre Sansão! De agora em diante, passarei apenas a transmitir vossas notícias..."

Sansão/Horácio: "Vá, vá, vá..."

Locutor: Povo de Gaza, atenção! atenção! A Rádio Gazeteira, a preferida dos ouvintes, passa a um novo programa. Votai em Sansão para um governo de ação..."

Sansão/Horácio (fala pelo microfone da rádio): "Sansão é o maior!"

Locutor: "Tem razão!"

Sansão/Horácio: "Obrigado."

Locutor: "Sansão faz o que promete. E Sansão anuncia a próxima novidade para os gazeteiros: a televisão. (voz em off, imagem de aparelho de rádio em primeiro plano; zoom out abre plano geral) Aguardai a maravilha do século. Numa oferta gentil de Sansão, o governador que Gaza precisa. Votai em Sansão, o homem que..." (o guerreiro Artur, chefe da guarda, desliga o rádio).

Artur: "O ignóbil corso está ganhando popularidade."

Rei: "É um verdadeiro demônio. Não viu as coisas estranhas que ele inventou? Rádio, telefone, televisão, e..."

Artur: "Sansão precisa ser eliminado."

Guarda: "Mas como, se ele é invencível?"

Artur (olha a taça em que bebe vinho): "He, he, he, até mesmo um leão invencível pode morrer pela boca."

Rei: "O que dizeis Artur?"

Artur: "Deixai por minha conta. Esta noite durante a festa."

\section{A) Análise do Nível 1 - Verbal}


Para a leitura da série verbal, buscamos as marcas enunciativas de T2 em catorze termos-pivôs: Sansão, confusão, terra, rádio, patrocínio (patrocinado), pago, propaganda, política, perdão, ação, razão, televisão, popularidade, leão. Como expressões da língua, esses termos evocam contextos nos quais viveram povoados de intenções (Bakhtin, 1993a), remetendo às condições de produção e à conjuntura socio-histórica em que a enunciação se inscreve nos anos 50 . Não buscamos a vasta polissemia que essas palavras trazem, mas os sentidos que emergem da interação que umas estabelecem com as outras na seqüência textual e da relação com exterior que atravessa o enunciado.

Partindo dos termos-pivôs, o primeiro aspecto que nos chama atenção em T2 é a estrutura rimada de algumas seqüências, tais como:

"Não achais, poderoso Sansão, que essas novas leis estão criando confusão?"

"Votai em Sansão para um governo de ação..."

"E Sansão anuncia a próxima novidade para os gazeteiros: a televisão"

“Perdão, mestre Sansão!..."

"Sansão é o maior!" / "Tem razão!"

Com orientações semânticas diversas (argumentativa, coercitiva, assertiva), essas séries enunciativas têm em comum a forma rimada, amplamente 
utilizada como estilo lingüístico quer em textos épicos (por exemplo, o coro da tragédia), quer na linguagem metafórica, na poesia, na prosa ou na paródia. A literatura de cordel, em poesia ou prosa, vale-se da rima para narrar temas cotidianos, religiosos, políticos, lendas ou episódios históricos. Nas séries verbais de T2, a rima aproxima-se de enunciados populares nos quais circulam os traços da fala coloquial cotidiana (Sansão - confusão; Sansão - ação; perdão - Sansão etc.). Por outro lado, nas mesmas séries e em outras no decorrer do texto verificamos a absorção da linguagem épica, expressa pelo uso cortês das formas dos dêiticos verbais (achais, votai, dizeis).

Essa apropriação de duas linguagens, a popular e a erudita, configura-se como uma característica recorrente da formação discursiva chanchada e como um traço da bivocalidade da palavra dialógica, própria do discurso parodístico, em que ocorrem num mesmo enunciado duas orientações semânticas, duas vozes centrais (neste caso, T2 e T1).

O discurso parodístico materializado em T2 deriva, em primeira instância, do filme Sansão e Dalila $(1951)^{75}$, texto-fonte (T1) a partir do qual esse discurso

\footnotetext{
75 O épico Sansão e Dalila (Samson and Delilah), de Cecil B. de Mille, lançado em 1951, é inspirado num episódio bíblico, narrado no Livro Juízes, do capítulo 13 ao 16 . Seguindo o padrão dos filmes épicos da época, Hollywood transforma esse episódio numa superprodução. Sansão era um homem de força descomunal e líder do povo danita, que vivia em Gaza escravizado pelos filisteus há 40 anos. Apaixonado por Dalila, uma filistéia, Sansão volta-se contra o seu povo, que nele depositara a esperança de libertação. Dalila, após conquistar a confiança de
} 
desdobra-se em outras paródias no interior do enunciado, isto é, em vozes que se fazem presentes no embate interdiscursivo. Como observa Vieira (1995), a paródia assume diversas formas no cinema brasileiro. Particularmente na chanchada Nem Sansão nem Dalila (1954), a paródia segue aproximadamente a estrutura narrativa do filme original (Dalila trai Sansão, Sansão é preso etc.), mas diferentemente do enredo norte-ameriano, cuja ideologia é o culto ao herói americano $^{76}$, a idéia central volta-se para a sátira política e social. A paródia, lembra-nos Bakhtin, tem várias gradações, pois é possível parodiar a maneira típico-social de o outro pensar e falar ou parodiar "apenas as formas superficiais do discurso" ou "até mesmo os princípios profundos do discurso do outro" (1997, p. 194).

A dupla identidade da personagem Sansão/Horácio constitui-se um dos rastros enunciativos centrais do discurso parodístico em T2, pois é a partir dessa duplicidade que se evidencia a paródia ao Estado getulista. Da alocução de Sansão/Horácio emerge a voz do governo populista de Getúlio Vargas, marcadamente presente nos termos-pivôs confusão, terra e rádio:

Sansão, descobre o segredo da sua força e o trai, cortando o seu cabelo. Sem força para lutar, Sansão é preso, torturado e humilhado. Arrepende-se de ter traído o seu povo e pede perdão a Deus. Alcança a redenção e recupera a força, derrubando o templo dos filisteus e desarticulando o poder daqueles que massacravam o seu povo. A morte triunfal, no final, em nome da justiça divina, completa o caminho da redenção do herói.

${ }^{76} \mathrm{Na}$ década de 50 , os heróis dos filmes norte-americanos eram idealizados com superpoderes físicos, com retidão de caráter e devoção a grandes causas. Quando Sansão e Dalila foi lançado, em 1951, apenas três anos após o fim da Segunda Guerra Mundial, a orientação ideológica do cinema hegemônico hollywoodiano voltava-se para enredos de cunho triunfalista, em que estivesse implícita a supremacia americana. Sansão e Dalila, assim como outros filmes posteriores povoados de heróis, representa a força do homem americano. 
"He, he, he, deixa a confusão. O governo é isso mesmo. Pelo menos na minha Terra é assim, he, he... Ah, deixa eu ouvir meu programa de rádio."

Os termos terra, confusão e rádio, encadeados na seqüência textual, remetem a outras palavras marcadas ideologicamente como nação, baderna e radiodifusão, pois toda produção discursiva, como assinala Maingueneau (1989), surge numa conjuntura dada, colocando em movimento formulações anteriores já enunciadas, ou seja, ativando a memória discursiva que circula entre as formações discursivas que repetem, recusam e transformam essas formulações no interdiscurso.

Em T2, esses termos estão carregados de um semantismo negativo, simbolicamente vinculado à idéia de um Estado negligente. A palavra terra é o lugar socio-histórico associado à personagem Horácio, isto é, à nação brasileira, ao Rio de Janeiro dos anos 50, então Distrito Federal, onde a política é regida sob o signo da confusão, da baderna, da marmelada ou negociata. No enunciado, o termo confusão afigura-se como a estratégia política de um Estado sem transparência, no qual prevalece a ausência de organização social. As leis sancionadas por Sansão para dar sustentação à política nacionaldesenvolvimentista confundem a população de Gaza, pois essas medidas são a 
base da ideologia demagógica-populista, que escamoteia as debilidades do governo atenuando as contradições sociais.

\footnotetext{
“Todos os dias serão feriados, menos o Dia do Trabalho"6

"Fica instituída a burocracia"77

“E Sansão anuncia a próxima novidade para os gazeteiros: a televisão"
}

Para o governo getulista, a radiodifusão tinha uma função educativoideológica, moral, cívica e higienista, pois o rádio constituía-se o veículo de integração de um público disperso territorialmente, num país onde mais da metade da população ${ }^{78}$ não era alfabetizada. 0 grande alcance da mídia radiofônica desperta o interesse do político Sansão/Horácio na programação de rádio; para o político o programa é propriedade do Estado:

“Ah, deixa eu ouvir meu programa de rádio”

Mas quais outros sentidos emergem de T2 como não-dito, implícito? Da alocução do locutor do rádio, predomina a voz do patrocinador (propaganda comercial). Nesse trecho de T2, a linguagem publicitária no rádio oscila da propaganda comercial à propaganda política. Considerando os termos-pivôs pago, propaganda, política, patrocínio, perdão, ação, razão, televisão, popularidade e 


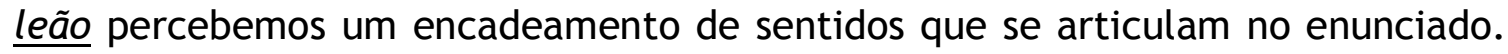
A palavra rádio, como apontamos anteriormente, remete à emissora líder nacional de audiência nos anos 50, a Rádio Nacional. Apesar de ter sido estatizada pelo governo de Getúlio Vargas na década de 40, a trajetória da Rádio Nacional foi pautada por uma lógica de produção comercial.

Esse aspecto mercadológico está marcado em T2 na narração do locutor, que sempre inicia os programas da rádio anunciando os patrocinadores, como nos exemplos a seguir:

“Patrocinado pelo leite de cabra Samur, o único legítimo, puro e sem água,..."

“...Não deixai de ir esta noite à boate Gazeli, o melhor espetáculo da cidade... Preços baratíssimos e uísque legítimo..."

"E agora, num patrocínio exclusivo do Bazar Zacarias, voltamos a apresentar...”.

O termo-pivô patrocínio demarca a orientação coercitiva das séries verbais proferidas pelo locutor. Os produtos, anunciados em formato de jingle, são uma marca dos anos 50, quando o mercado publicitário cresce particularmente nas rádios $^{79}$ e surgem novas técnicas de marketing, introduzidas pelas multinacionais.

\footnotetext{
${ }^{77}$ Estas séries estão presentes num narratema anterior, em que Sansão/Horácio dita à assessora Miriam as novas medidas implementadas por seu governo.

${ }^{78} \mathrm{Na}$ década de 50 , havia em média 80 milhões de habitantes no Brasil.

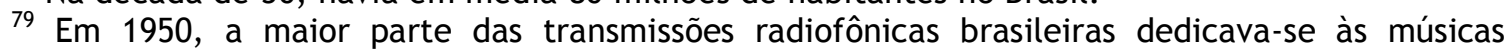
populares e folclóricas, que perfazem um total de 34\% da programação. Em segundo lugar,
} 
O tempo permitido para a veiculação de comerciais duplica nas rádios brasileiras, saltando para $20 \%$ da programação diária.

O espaço para a notícia, como podemos observar em T2, é bem menor do que o espaço dedicado aos anúncios:

“...Atenção! Atenção! A partir de amanhã, o tráfego na rua principal será feito em mão única..."

A voz do governo populista (propaganda política) emerge das relações de sentidos que se estabelecem entre os termos-pivôs pago, propaganda, política, perdão, $\underline{\text { ação }}, \underline{\text { razão, }} \underline{\text { televisão, }}$ popularidade e leão. Essa voz, que se impõe à programação da rádio, evidencia o caráter autoritário do governo populista de Sansão/Horácio, numa paródia satírica ao controle da Rádio Nacional pelo governo. Esse controle era exercido tanto para fins educativos, como para fins de propaganda política do governo. O programa A hora do Brasil, foi criado em 1939 junto com o Departamento de Imprensa e Propaganda (DIP), órgão de censura e propaganda do Estado Novo.

estão as propagandas comerciais girando em torno dos $20 \%$ legalmente instituídos. Nas terceira e quarta posições, têm-se o que foi identificado no censo de 1950 como "música ligeira" e "música de classe”. O restante da programação, seguindo a classificação censitária, divide-se, em ordem decrescente, entre: notícias e comentários jornalísticos, transmissões e comentários desportivos, programas de auditório, representações teatrais, programas instrutivos, programas infanto-juvenis, programas humorísticos, propaganda política, programas femininos, conferências e palestras, cursos e programas de ginástica. 0 uso do rádio como veículo pedagógico de moral e civismo ficou mais restrito às emissoras estatais, que ocupavam, em 
A palavra perdão remete à submissão das empresas ao Estado autoritário. Em T2, Sansão/Horácio assume o poder pela imposição de sua força, anunciando sua plataforma política com a criação de novas leis e benefícios trabalhistas durante a campanha à "presidência” de Gaza. Embora o mandato de Getúlio Vargas fosse democrático no momento da realização de Nem Sansão nem Dalila o filme foi rodado no início de 1954, meses antes do suicídio de Vargas -, ainda não fazia dez anos do fim do Estado Novo ${ }^{80}$. 0 perdão retifica a ordem do governo, redefine o espaço publicitário do Estado na rádio. A Rádio Gazeteira, a preferida dos ouvintes (outra marca enunciativa que remete à Rádio Nacional, que era a emissora de maior audiência nos anos 50), passa da propaganda comercial para a propaganda política.

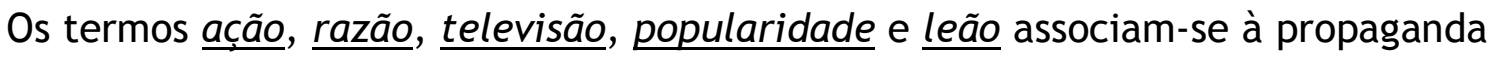
política das ações populistas do governo getulista, difundidas pela Rádio Nacional. Nessa seqüência de T2, destaca-se o slogan político de Sansão/Horácio:

"Votai em Sansão para um governo de ação"

1944, aproximadamente $5 \%$ do universo radiofônico (dados extraídos do site http://www.ifch.unicamp.br).

${ }^{80}$ Getúlio Vargas foi presidente da República por quatro vezes. Governou o Brasil de 1930 a 1934 no Governo Provisório; de 1934 a 1937, no governo constitucional, eleito pelo Congresso Nacional; de 1937 a 1945, no regime autoritário do Estado Novo; e de 1951 a 1954, como presidente eleito pelo voto direto. 
A série, com orientação coercitiva, apropria-se da forma rimada para produzir um efeito de sentido que aproxima o ato político (sanção das leis, dos decretos etc.) da atuação/peformance. A ação é promessa, e "Sansão faz o que promete". A seqüência, articulada numa linguagem prosaica, repete, na memória discursiva, outras formulações familiares à massa de eleitores.

O termo razão, cuja orientação semântica é assertiva em T2, remete à auto-promoção, ao marketing político legitimado pela mídia rádio:

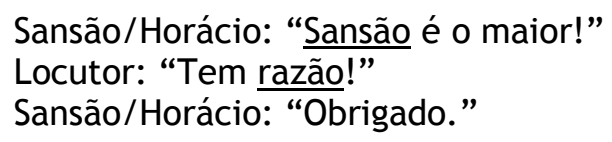

O marketing político afirma que Sansão/Horácio “faz o que promete”, e a grande promessa do século é a televisão, a “maravilha” que revolucionará o campo das comunicações, anunciada em T2 ironicamente pelo rádio, meio que reforça a popularidade de Sansão/Horácio. O termo popularidade no enunciado representa a grande conquista política para um governo populista, fortalecendo a imagem do imbatível Sansão/Horácio. Mas, por outro lado, traz as marcas de sentidos negativos, podendo ser lida como estágio que desperta a intriga da oposição. Diz Artur, o oponente de Sansão/Horácio:

“...até mesmo um leão invencível pode morrer pela boca.” 
Esta seqüência, cuja característica é o deslocamento matafórico, fecha o sentido do narratema no plano verbal. Em relação ao contexto histórico, em 1954, Getúlio Vargas, em seu quarto mandato como presidente do Brasil, apesar da imensa aceitação popular, conduzia um governo desgastado pela oposição e defrontou-se com tramas de vingança e tentativa de assassinato.

B) Análise dos Níveis 2 e 3 - Visual e Sonoro

As séries visual e sonora do narratema "Votai em Sansão, um homem de ação" (T2) desenvolvem-se em três minutos dos 90 que compõem a narrativa de Nem Sansão Nem Dalila, segmentada neste estudo, a título localização do narratema no espaço diegético, em três grandes movimentos: 1) O Rio de Janeiro em 1954; 2) Gaza em 1.130 a.C.; 3) De volta ao Rio de Janeiro em 1954, onde se dá o desenlace. O narratema (T2) circunscreve-se numa longa seqüência do segundo movimento, que se inicia no gabinete de Sansão/Horácio, ditando à sua assessora Miriam as novas leis de Gaza.

Para a leitura dos níveis visual e sonoro, consideramos as modalidades diegéticas ponto de vista, tipologia das personagens e espaço-tempo (como ambiente socio-ideológico).

Em relação à mídia rádio, o foco narrativo de $\mathrm{T} 2$ apresenta três pontos de vista: a perspectiva do protagonista Sansão/Horácio; a visão da coadjuvante 
Miriam, assessora de Sansão/Horácio; e a ótica de Artur, o antogonista que faz oposição ao governo de Sansão/Horácio.

O narratema T2 é constituído de longos planos, geralmente médios, com poucas alternâncias entre campo e contra-campo. Os movimentos de câmera, raros, são empregados com suaves panorâmicas ou zooms para introduzir o aparelho de rádio, em primeiro plano, no campo.

O ponto de vista de Sansão/Horácio em relação ao rádio é o do governo centralizador e populista, em plena campanha eleitoral. Ao assumir o poder de Gaza impondo a sua força, Sansão/Horácio estabelece uma série de decretos visando à consolidação do poder pelo voto direto. Para avançar nesse projeto, a personagem tem no rádio uma mídia estratégica para a sua propaganda política. A cena fílmica em que Sansão/Horácio escuta a transmissão da Rádio Gazeteira, junto com a assistente Miriam, é apresentada em plano médio, ao fundo lê-se um painel com o slogan da campanha política de Sansão/Horácio: “Votai em Sansão, um homem de ação". No entanto, praticamente durante toda a cena, Sansão/Horácio e Miriam, permanecem sentados. A seqüência do gabinete, desde a abertura em que o estadista prepara sua plataforma política, até o momento em que escuta a programação do rádio, não há praticamente ação, se comparada com outras seqüências do filme, em que há cenas de dança, prisões, fuga e lutas; a composição visual de T2 apresenta poucos movimentos de câmera e das personagens. 
O slogan tem uma proximidade semântica com o transmitido pela rádio: “Votai em Sansão, para um governo de ação”. Como o rádio, na perspectiva de Sansão/Horácio, não está cumprindo o papel de veículo do Estado populista, ocupando a programação com anúncios, Sansão interfere na programação, controlando o discurso radiofônico.

$\mathrm{Na}$ ótica de Miriam, a programação da rádio está a contento, pois a personagem incorpora a voz das massas populares, a audiência que ouve a Rádio Gazeteira e dá sustentação à ciranda de consumo de bens materiais e simbólicos que está em ascensão no Reino de Gaza.

Artur, posicionado como ouvinte que se opõe à política de Sansão/Horácio, tem o ponto de vista de que o meio rádio está aumentando a popularidade do estadista, por isso planeja envenená-lo. A cena, em que afirma que "até um leão invencível pode morrer pela boca",

Em T2, o rádio media as relações entre as personagens e seus pontos de vista no espaço-tempo diegético.

Quanto à tipologia, interessa-nos a dupla identidade de Sansão/Horácio, que, junto com a série dialogada, é um dos elementos diegéticos que materializa em T2 o discurso parodístico aos textos-fontes Sansão e Dalila, governo de 
Getúlio Vargas e Rádio Nacional. Essa duplicidade é conferida a Horácio através de um adereço: uma peruca que lhe proporciona poderes mágicos.

A força que emana da peruca de Sansão/Horácio é um elemento próprio do princípio carnavalesco que permeia as chanchadas, remetendo ao travestimento, à inversão de papéis, à redefinição do espaço oficial e não-oficial na sociedade. Sansão/Horácio é um herói às avessas. Franzino, sem os músculos à mostra, nem o porte "greco-romano", nem os cabelos "naturais” do Sansão norte-americano (Victor Mature), o Sansão da chanchada brasileira utiliza-se de um adereço para ter força, um artifício próprio ao Carnaval e à carnavalização em que o riso festivo transforma o pobre do morro em rei momo, assalariado em político, num movimento contínuo em que o periférico torna-se o centro. Esse é o princípio carnavalesco assinalado por Bakhtin (1993b). Em toda narrativa e em T2, a peruca é o objeto central para o desenrolar da trama, pois é portadora da conotação política de que é preciso valer-se de um artifício para conquistar o poder.

Associada à interpretação de Oscarito, entusiasta da improvisação com gags chistosas, e à precariedade do conjunto narrativo (figurinos e cenários em estilo épico), a peruca imprime um efeito cômico à personagem Sansão/Horácio. Antes do travestimento com a peruca, no primeiro movimento da narrativa, Horácio já é um anti-herói cômico, uma espécie de pilantra trapalhão que mescla a ingenuidade do homem simples com a sagacidade do trabalhador assalariado. 
Mesmo depois de se transformar no poderoso Sansão, a personagem também mantém parte da identidade original: o corpo franzino e o jeitinho zombador do brasileiro que satiriza os estrangeiros de Gaza e a própria terra Brasil. Mas não é apenas Horácio quem mantém o seu duplo em Sansão. Outras personagens que trabalhavam no Salão Dalila, no Rio de Janeiro de 1954, como as manicures Miriam (Fada Santoro) e Dalila (Eliana), tornam-se filhas do mercador Tubal (Sérgio de Oliveira) em Gaza.

É com esse perfil duplo que Sansão/Horácio transita no espaço-tempo diegético, um ambiente social que se assemelha ao Brasil, com corrupção no governo, precariedade no transporte coletivo, produtos contrabandeados, ruas esburacadas, problemas verificados no Rio de Janeiro de 1954. A mídia rádio ocupa posição central nesse universo diegético, em que há o controle da informação pelo Estado.

No espaço-tempo de T2 a televisão não é presentificada como objeto, mas aludida através do rádio. Quando o locutor anuncia "a próxima novidade para os gazeteiros: a televisão", uma rápida panorâmica seguida de zoom focaliza o aparelho de rádio do estúdio. Uma montagem paralela cria um efeito narrativo cujo sentido é irônico: enquanto o locutor ainda pronuncia a palavra televisão, o som invade o primeiro plano da cena seguinte, em que o foco é outro aparelho de rádio em primeiro plano. E voz do locutor em off continua: ...televisão. Aguardai a maravilha do século. Mas o que 
se vê no campo é caixa acústica de um aparelho radiofônico antigo. As novidades “inventadas” por Sansão/Horácio em Gaza, como telefone, rádio, são representadas no espaço-tempo como peças de museu. Esses objetos simbolizam, metaforicamente, a precariedade do subdesenvolvimento brasileiro mesmo na busca pela modernização.

Geralmente, no nível sonoro, os diálogos transcorrem em som direto. A interferência sonora que chama atenção é o jingle do leite de cabra Samur, que patrocina o programa da Rádio Gazeiteira. O jingle acentua a comicidade da cena ao se apropriar do estilo árabe de cantar, introduzindo um "beeé" de cabra.

Apenas aludida ironicamente pelo rádio como a "maravilha do século", a televisão tem uma participação mais ampla em outras narrativas chanchadescas. Em Absolutamente certo (1957), cujo enredo gira em torno de um programa de TV de acertos e erros, a televisão é satirizada numa cena paródica ao programa 0 céu é o limite, apresentado nos 50, em São Paulo, pelo radialista Aurélio Campos, famoso pelo bordão "absolutamente certo". A paródia, nesse filme, situa-se numa fronteira tênue com a alusão, pois é menos exagerada do que outras paródias chanchadescas. O efeito cômico não é criado pela personagem Aurélio Campos (Luiz Orine), mas por Dona Bela (Dercy Gonçalves), cuja representação caricatural satiriza a TV. Ao assistir ao programa “Absolutamente Certo”, Dona Bela retruca: “Esse programa é de morte, só têm luta de boxe, jogo de futebol que não se vê a bola, gente de cabeça cortada dançando mambo!”. Única telespectadora a possuir um 
aparelho de TV, pois o custo era alto nos anos 50, Dona Bela cobra uma taxa dos vizinhos que são fãs do programa “Absolutamente Certo". O aspecto comercial da televisão, que era um meio extremamente dependente dos patrocinadores, também é destacado em Absolutamente certo.

A chanchada Com Água na boca (1956), em que os palhaços Carequinha (Carequinha) e Fred (Fred Villar) e a mocinha Marina (Anilza Leoni) tornam-se estrelas de televisão, satiriza os comerciais de eletrodomésticos na TV. Desajeitada ao demonstrar o uso de produtos como liqüidificador, enceradeira e batedeira, a garata-propaganda Marina arranca risos do auditório (naquela época os programas eram feitos ao vivo, com platéia), deixando o diretor da TV preocupado com os patrocinadores.

\subsection{A BARONESA TRANSVIADA, O CINEMA E A MÍDIA IMPRESSA}

\subsection{1. “Cinema indígena" - Narratema 2}

O narratema "Cinema indígena" foi delimitado de $A$ baronesa transviada $(1957)^{81}$ por se afigurar como um enunciado em que o discurso irônico se faz

\footnotetext{
${ }^{81}$ Sinopse: A Baronesa Transviada narra a história da manicure Gonçalina Piaçava da Silva, que sonha ser atriz de cinema, porém suas tentativas são todas frustradas. Ao herdar, num golpe de sorte, a fortuna de uma velha baronesa que a reconhece como filha legítima, Gonçalina decide investir todo o seu capital no cinema. 0 produtor Ambrósio Bezerra, que trabalha num estúdio à beira da falência, toma conhecimento pelo jornal das intenções da ex-manicure e resolve proporthe um negócio. A baronesa Gonçalina aceita a proposta de Bezerra e aplica seu dinheiro no
} 
predominante. Esse narratema pode ser tomado como uma síntese da interação da chanchada com o cinema nos anos 50, da posição de estigmatizada que ocupava no contexto de produção cinematográfica daquele período.

Vejamos a seqüência verbal de "Cinema indígena":

Ambrósio Bezerra/diretor de cinema: (rindo à mesa): “A senhora baronesa tem muita graça, he, he, he... O cinema nacional precisa de uma mulher da sua envergadura."

Gonçalina/Baronesa: "Ele disse que eu uso ferradura?"

Eduardo: "Não, Gonçalina, ele disse envergadura."

Gonçalina/Baronesa: "Ah, cavalgadura, he, he, he."

Ambrósio Bezerra/diretor de cinema: "A senhora pode se tornar a Lolobrigida do cinema nacional."

Gonçalina/Baronesa: "Engraçado, outras pessoas já me falaram nessa semelhança, he, he, he."

Ambrósio Bezerra/diretor de cinema: "Nós pretendemos fazer filmes em cinemascope, starvision, em alto-relevo..."

Gonçalina/Baronesa: "He, he, he..."

Ambrósio Bezerra/diretor de cinema: "Nós os cineastas que fazemos cinema nacional precisamos de pessoas inteligentes como a senhora baronesa."

Gonçalina/Baronesa: "Inteligente é o cor de abóbora, que tem o Pedro Álvares Cabral nas costas, he, he, he..."

Ambrósio Bezerra/diretor de cinema: "He, he, he, a Baronesa tem muito espírito!"

Gonçalina/Baronesa: "Essa foi direta, he, he, he..." (todos riem)

Ambrósio Bezerra/diretor de cinema: "A senhora Baronesa com todo o seu dinheiro e nós com a nossa experiência podemos mudar o rumo do cinema nacional!"

Gonçalina/Baronesa: "Isso mesmo, muito bem. Se é para o bem de todos e a felicidade geral do cinema indígena, amanhã estaremos quites."

Ambrósio Bezerra: "Muito bem, e eu estou certo que a senhora Baronesa não se arrependerá."

Gonçalina/Baronesa: (cumprimenta todos com um aperto de mãos):

“Ótimo, ótimo, que ótimo!"

estúdio, sob a promessa de que irá protagonizar uma comédia musical. No entanto, Gonçalina terá de enfrentar produtores inescrupulosos e a família maldosa da falecida velha baronesa. 


\section{A) Análise do Nível 1 - Verbal}

O que primeiramente nos chama a atenção no narratema são os termos marcados ideologicamente, como nação, cinema, nacional e indígena. Essas expressões comportam uma memória discursiva de um Brasil concebido como subdesenvolvido em diversas esferas, particularmente no campo da produção cinematográfica se comparado com o cinema hegemônico de Hollywood. A construção cinema indígena carrega um semantismo ao mesmo tempo negativo e irônico:

\footnotetext{
"Se é para o bem de todos e felicidade geral do cinema indígena, amanhã estaremos todos quites."
}

Negativo ao associar o cinema nacional ao que é indígena, selvagem, popular no sentido do subdesenvolvido. Em outro narratema, quando Gonçalina ainda é uma simples manicure e diz que seu sobrenome é "Piaçava" ao diretor de cinema Ambrósio, ele confirma em tom de estranhamento: “Piaçava?” Gonçalina responde: “É, é indígena”. Ora, Gonçalina, além de pertencer a uma classe social desprovida economicamente, foi encontrada numa lata de lixo quando recémnascida. Considerando as marcas da enunciação e o contexto histórico do Brasil nos anos 50 (as tribos indígenas viviam bastante isoladas da cultura urbana), podemos deduzir os sentidos que essa palavra carregava. 
O discurso irônico, neste caso, materializa-se na estrutura de uma enunciado de cunho sentencial, histórico, relacionado com o período colonial do país: "Se é para o bem geral de todos e felicidade geral da nação, eu fico" (texto 1). Enunciados desse tipo designam uma linguagem familiar e simbólica. Uma proposição de tipo sentencial com traçado verbal bem arcaico que constitui por si só um espetáculo. No texto 2 Gonçalina lança mão da estrutura sentencial subvertendo a autoridade desse dizer e imprimindo autoridade a novos dizeres. Esse desvio consiste em produzir um enunciado com as marcas lingüísticas de outra enunciação conferindo-lhe um novo acento, contradizendo-o. A ironia manifesta-se no duplo sentido, no emprego ambíguo que contraria e contradiz o discurso original. A idéia de nação cujo cinema é indígena remete ao subdesenvolvimento do cinema nacional.

A ironia permeia outras seqüências do diálogo entre Ambrósio e Gonçalina no narratema, como:

Nós pretendemos fazer filmes em cinemascope, starvision, em altorelevo..."

“Nós os cineastas que fazemos cinema nacional precisamos de pessoas inteligentes como a senhora baronesa” 
O discurso irônico é dirigido ao próprio cinema nacional e torna-se mais transparente quando materializado nos dois níveis (verbal e extra-verbal): enquanto Ambrósico faz essas promessas, Gonçalina ri e balança a cabeça, como se dissesse ironicamente: “Ah, sei, sei..”.

Mais duas séries carregam têm a orientação irônica, ao se voltar para palavra comum e para um outro discurso, apropriando-se do enunciado original para contradizê-lo, com uma idéia oposta, acentuando o duplo sentido, a ambivalência:

"A senhora pode se tornar a Lolobrigida do cinema nacional."

“Inteligente é o cor de abóbora, que tem o Pedro Álvares Cabral nas costas, he, he, he..."

A primeira seqüência, a princípio uma falsa promessa, tem uma orientação irônica por ressiginificar o mito do cinema italiano (é a Lolobrigida, mas do cinema nacional). A segunda série refere-se ironicamente ao capital, dinheiro, que determina os rumos do cinema nacional.

Desse conjunto irônico, emergem: a voz do cinema subdesenvolvido (cinema indígena nacional), a voz do cinema estrangeiro (Lolobrigida, starvision, alto-relevo) e voz do capital (cor de abóbora).

O narratema é uma síntese do contrato ideológico primordial sobre o qual se desenvolve a idéia central de $A$ baronesa transviada: a promessa de mudança 
do rumo do cinema nacional constitui uma espécie de garantia, de troca na negociação que visa o capital da baronesa. Em troca, Gonçalina trabalhará numa chanchada.

\section{B) Análise do Nível 2 - Visual e Sonoro}

O narratema inicia-se com um plano geral, no qual se vê a opulência do jantar oferecido pela baronesa/Gonçalina. Há dois pontos de vista: a percepção de Gonçalina do que cinema nacional e a visão do diretor Ambrósio do que é cinema nacional. Ao ironizar cunhando o cinema nacional de indígena, Gonçalina ao mesmo tempo reconhece as reais condições de um cinema subdesenvolvido. 0 seu projeto é fazer um cinema cômico-popular, dirigido ao povo. Dessa ótica, emerge a voz da chanchada. Tanto A baronesa transviada (1957) como Carnaval Atlântida (1952) podem ser lidos como filmes-manifesto do gênero chanchada. No primeiro, há o reconhecimento de que não é possível realizar no Brasil uma superprodução nos padrões do cinema hegemônico (o diretor Cecil B. de Milho, uma paródia a Cecil B. de Mille, interrompe o projeto de filmagem de Helena de Tróia e realiza uma comédia musical carnavalesca). No segundo, o projeto emana de uma personagem com características populares e que acredita num cinema voltado para o riso.

O ponto de vista de Ambrósio é do diretor/produtor que precisa do capital para realizar os projetos de seu estúdio, cujos filmes são melodramáticos. Essa 
visão muda no decorrer da narrativa, cujo desenlace acontece com a exibição de uma comédia em que Gonçalina/Baronesa é a protagonista.

Em relação ao espaço-tempo o narratema desenrrola-se no Castelo da Baronesa/Gonçalina, onde é selado o acordo de “mudar o rumo de cinema nacional”. Nesse caso, o cinema popular, a chanchada, também se constitui uma burguesa, uma elite com a visão mais parcimoniosa do que é investimento no nacional.

Em outros narratemas de $A$ Baronesa transviada a imprensa é aludida e o jornal O Globo noticia em primeira página quando Gonçalina herda os milhões da velha baronesa. São referências pontuais. O Homem do Sptunik (1959) é o filme cuja narrativa volta-se essencialmente para a mídia impressa. Nesse filme, há a defesa da credibilidade como o principal tributo da imprensa. Permeado pela ambivalência, o discurso desta chanchada constrói personagens jornalistas ora “bons moços”, endeusando-os, ora "vilões”. Tendo retratado, essencialmente, o conflito entre cultura popular e de elite no Brasil dos anos 50, com sua comicidade crítica (o discurso cômico-irônico), O homem do Sputnik (1959) evidencia as vozes, construídas no discurso polifônico, entre personagens do povo e da alta sociedade. Em seu discurso paródico e carnavalizado, o filme cria encontros discursivos, apresenta diversidade de vozes, cortesia e descortesia, nobreza e vulgaridade 


\section{CONCLUSÃO}

A proposta inicial de analisar o diálogo da chanchada com a mídia resultou num estudo ao mesmo tempo desafiador e estimulante. Mergulhar no universo dos filmes chanchadescos e dele extrair as marcas discursirvas que emergem da interação com os meios de comunicação na década de 50 permitiu responder, senão a todas, pelo menos a algumas indagações às quais nos propusemos neste trabalho.

O primeiro aspecto a ser destacado diz respeito ao período histórico delimitado para a análise. Entendido a princípio como um momento em que há uma dicotomia entre o culto e popular marcadamente presente no campo da produção cinematográfica, a década de 50 revelou uma mobilidade entre essas fronteiras bem maior do que havíamos suposto.

A lógica da mercantilização, que abriu o caminho para a consolidação de uma cultura de massas nos grandes centros urbanos nos anos 50 , permitiu uma maior interação entre os meios de comunicação. O diálogo da chanchada com esses meios revela esse aspecto.

Na relação dialógica da chanchada com a mídia de sua época, percebemos alguns posicionamentos gerais de cada meio de comunicação: da mídia impressa emerge a voz estigmatizadora, dominada pelas elites; da mídia radiofônica, a voz 
inspiradora, complementar, que estabeleceu uma cumplicidade com a chanchada âmbito da linguagem popular; da televisão, a voz da publicidade; e da mídia cinematográfica, a voz do cinema industrial carioca e da burguesia paulista. Essas vozes, evidentemente, não são se enquadram em categorias estanques.

No entanto, percebemos que uma voz central permeia essa rede interdiscursiva que se processa na interação entre chanchada e mídia: a da propaganda, quer comercial, quer política. Por seu turno, o diálogo da chanchada com a mídia processou-se a partir da posição estigmatizada que essa produção cinematográfica ocupou no contexto sócio-histórico dos anos 50.

Dessa posição, a chanchada mesclou o popular, o culto e o massivo (os meios de comunicação de massa) em suas comédias, transportando para o cinema matrizes culturais em conflito, colocando em evidência a cisão entre elite e povo no cenário urbano-industrial brasileiro dos anos 40 e 50 . Nos filmes chanchadescos, costumes urbanos se misturavam aos rurais, histórias míticas (greco-romanas) se fundiam com tipos brasileiros e o carnaval se mesclava com paródias a gêneros de filmes norteamericanos (musical, policial, western, reconstrução de épocas). Eis a fórmula da chanchada para construir sua narrativa cômica.). 


\section{BIBLIOGRAFIA}

ABREU, Alzira Alves de (org.); RAMOS, Plínio de Abreu et al. A imprensa em transição: o jornalismo brasileiro nos anos 50. Rio de Janeiro: Fundação Getulio Vargas, 1996.

ASSAF, Alice Gonzaga. 50 Anos de Cinédia. Rio de Janeiro: Record, 1987.

AUGUSTO, Sérgio. Este mundo é um pandeiro: a chanchada de Getúlio a JK. São Paulo: Companhia das Letras/Cinemateca Brasileira, 1989.

AUMONT, Jacques et al. A estética do filme. Trad. Marina Appenzeller. Campinas, SP: Papirus, 1995.

; MARIE, Michel. L'analyse des films. Paris: Nathan, 1988.

ALTHUSSER, Louis. Ideologia e aparelhos ideológicos de Estado. Trad. J. J. Moura Ramos. Lisboa: Presença, Martins Fontes, 1974.

BAKHTIN, M.M. Questões de literatura e de estética: a teoria do romance. $3^{a}$ ed. São Paulo: Unesp/Hucitec, 1993a.

A cultura popular na Idade Média e no Renascimento: o contexto de François Rabelais. Trad. Yara Frateschi. $2^{\mathrm{a}}$ ed. São Paulo-Brasília: Edunb/Hucitec: 1993b.

. Problemas da poética de Dostoiévski. $2^{\mathrm{a}}$ ed. rev. Rio de Janeiro: Forense Universitária, 1997.

(Volochinov, 1929). Marxismo e filosofia da linguagem: problemas fundamentais do método sociológico na ciência da linguagem. $11^{\circ}$ ed. São Paulo: Hucitec, 2004.

BARROS, Diana Luz Pessoa de. "Contribuições de Bakhtin às teorias do discurso". In: Bakhtin, dialogismo e construção do sentido. Brait, Beth (org.). Campinas, SP: Editora da Unicamp, 1997.

BARROS, Luiz de. Minhas memórias de cinema. Rio de Janeiro: Arte Nova / Embrafilme, 1978.

BARTHES, Roland. “Introdução à análise estrutural da narrativa”. In: Análise estrutural da narrativa: pesquisas semiológicas. Trad. Maria Zélia Barbosa Pinto. $3^{\mathrm{a}}$ ed. Petrópolis, Rio de Janeiro: Vozes, 1973. 
BENVENISTE, Emile. Problèmes de linguistique générale. Paris: Gallimard, 1966. BERNARDET, Jean-Claude. Brasil em tempo de cinema. Rio de Janeiro: Civilização Brasileira, 1967.

. O que é cinema. São Paulo, Brasiliense, 1980.

. Cinema brasileiro: propostas para uma história. Rio de Janeiro: Paz e Terra, 1979.

- Cinema brasileiro: propostas para uma história. Rio de Janeiro: Paz e Terra, 1979.

.Trajetória crítica. São Paulo: Polis, 1978.

BONITZER, Pascal. Le regard et la voix. Paris, 1976.

BRANDÃO, Helena N. "Análise do discurso: algumas balizas históricas". In: Subjetividade, argumentação e polifonia: a propaganda da Petrobrás. São Paulo: Unesp, 1998.

(org.). "Gêneros do discurso e tipos textuais". In: Gêneros do discurso na escola: mito, conto, cordel, discurso político, divulgação científica. São Paulo: Cortez, v. 5, 2000.

. “Da lingua ao discurso, do homogêneo ao heterogêneo". In: Estudos enunciativos do Brasil: histórias e perspectivas. Brait, Beth (org.). São Paulo: Fapesp, 2001.

. “Análise do discurso: um itinerário histórico". In: Língua, literatura e cultura em diálogo. PEREIRA, H.B.C. e ATIK, M.L.G. (orgs). São Paulo: Mackenzie, 2003.

Introdução à análise do discurso. $2^{\mathrm{a}}$ ed. rev. Campinas, SP: Editora da Unicamp, 2004.

BRAIT, Beth (org.). Bakhtin, dialogismo e construção do sentido. Campinas: Unicamp, 1997.

BRANIGAN, Edward. Point of view in the cinema. New York: Mouton, 1984.

BREMOND, Claude. "A lógica dos possíveis narrativos". In: Análise estrutural da narrativa: pesquisas semiológicas. Trad. Maria Zélia Barbosa Pinto. $3^{\mathrm{a}}$ ed. Petrópolis, Rio de Janeiro: Vozes, 1973. 
CÂNDIDO, Antonio; SALLES GOMES, Paulo Emílio; ROSENFELD, Anatol. A personagem de ficção. São Paulo: Perspectiva, 1972.

CASETTI, Francesco; DI CHIO, Federico. Cómo analizar un film. Barcelona: Paydos, 1991.

CASTRO, Maria Lília Dias de. “A dialogia e os efeitos de sentidos irônicos”. In: Bakhtin, dialogismo e construção do sentido. BRAIT, Beth (org.). Campinas: Unicamp, 1997.

CATANI, Afrânio M. e SOUZA, José I. de Melo. A chanchada no cinema brasileiro. São Paulo: Brasiliense, 1983.

(coord.) et al. Cinema popular brasileiro e a representação da malandragem: de Oscarito a Mário Fofoca, a chanchada e a telenovela humorística. Relatório Final de Pesquisa, Centro de Estudos Latino-Americanos sobre Cultura e Comunicação (CELACC), Universidade de São Paulo, 1998.

CHAIA, Miguel W. O tostão furado: um estudo sobre a chanchada. Dissertação de Mestrado, Universidade de São Paulo, mimeo., 1980.

CHARAUDEAU, Patrick e MAINGUENEAU, Dominique. Dicionário de análise do discurso. Trad. Fabiana Komesu (coord.). São Paulo: Contexto, 2004.

CHATMAN, Seymour. Story and discourse: narrative structure in fiction and film. Ithaca: Cornell University Press, 1993.

CLARK, Katerina e HOLQUIST, Michael. Bakhtin, Mikhail. Trad. Guinsburg. São Paulo: Perspectiva, 1998.

COSTE, Didier. Narrative as communication. Minneapolis: University of Minnesota Press, 1989.

COSTELLA, Antonio. Comunicação: do grito ao satélite. $2^{\mathrm{a}}$ ed. São Paulo: Editora Mantiqueira, 1984.

DIAS, Rosângela de Oliveira. 0 mundo como chanchada: cinema e imaginário das classes populares na década de 1950. Rio de Janeiro: Relume-Dumará, 1993.

DUCROT, Oswald. O dizer e o dito. Campinas, SP: Pontes, 1987.

. Princípios de semântica linguiística: dizer e não dizer. Trad. C. Vogt e outros. São Paulo: Cultrix, 1997.

EISENSTEIN, Serguei. Film Form. New York: Harcourt: Brace \& Company, 1949. 
ECO, Umberto. Les limites de l'interprétation. Grasset, 1992.

ECO, Umberto. Lector in fabula. Trad. Attílio Cancian. SP: Perspectiva, 1986.

FOUCAULT, Michel. Arqueologia do saber. 6. ed. Rio de Janeiro: Forense, 2000. ELIAS, Norbert e SCOTSON, John L. Os estabelecidos e os outsiders. Rio de Janeiro: Jorge Zahar, 2000.

FERREIRA, Aurélio Buarque de Holanda. Novo dicionário da língua portuguesa. $2^{\mathrm{a}}$ ed. Rio de Janeiro: Nova Fronteira, 1986.

FORD, Aníbal. Las fisuras de la industria cultural. Alternativa Latinoamericana, 1988.

GALVÃO, Maria Rita. Burguesia e cinema: o caso Vera Cruz. Rio de Janeiro: Civilização Brasileira, 1981.

e BERNARDET, J.C. Cinema: repercussões em caixa de eco ideológico. São Paulo: Brasiliense, 1983.

GARCÍA CANCLINI, Néstor. Culturas híbridas: estratégias para entrar e sair da modernidade. $3^{\mathrm{a}}$ ed. São Paulo: Edusp, 2000.

GENETTE, Gérard. Discurso da narrativa (Figures III). Trad. Fernando Cabral Martins. Lisboa: Coleção Vega Universidade, 1972.

GOMES, Angela de Castro (org.). O Brasil de JK. Rio de Janeiro: FGV / CPDOC, 1991.

GONZAGA, Adhemar e GOMES SALLES, Paulo Emílio. 70 anos de cinema brasileiro. Rio de Janeiro: Expressão e Cultura, 1966.

HOLQUIST, Michael. Dialogism: Bakhtin and his world. London and New York: Routledge, 1990.

http://www.ifch.unicamp.br/anphlac/anais/encontro4/ensaiob1.htm. Acesso em 23 fev. 2007.

http://www.atlantidacinematografica.com.br/. Acesso em 15 mar. 2004.

HOUAISS, Antônio; VILLAR, Mauro de Salles; MELLO FRANCO, Francisco Manoel.

Dicionário Houaiss da Língua Portuguesa. Rio de Janeiro: Objetiva, 2001.

IANNI, Octavio. "A questão nacional na América Latina”. In: Estudos Avançados. São Paulo, USP, jan-mar. 1988.

LEITE, Ligia Chiappini Moraes. 0 foco narrativo. 10ª ed. São Paulo: Ática, 2004. 
LEFEBVE, Maurice-Jean. Estrutura do discurso, da poesia e da narrativa. Trad. José Carlos Seabra Pereira. Coimbra - Portugal: Livraria Almedina, 1975.

LIMA, André Luiz Machado de. A imagem do jornalismo na chanchada brasileira: como a Atlântida representou a imprensa em seus filmes na década de 50. Monografia, Pontifícia Universidade Católica de São Paulo, 2002.

MACHADO, Irene A. 0 romance e a voz: a prosaica dialógica de Mikhail Bakhtin. Rio de Janeiro: Imago / São Paulo: Fapesp, 1995.

MAINGUENEAU, Dominique. Initiation aux méthodes de l'analyse du discours. Paris: Hachette, 1976.

Novas tendências em análise do discurso. Trad. Freda Indursky. Campinas, SP: Editora da Unicamp, 1989.

- Genèses du discours. Bruxelas: Marlaga, 1984.

MARTÍN-BARBERO, Jesús. Dos meios às mediações: Comunicação, cultura e hegemonia. Rio de Janeiro: Editora UFRJ, 1997.

MEIRELLES, William Reis. Paródia e chanchada: imagens do Brasil na cultura de classes populares. Londrina: Eduel, 2005.

MERTEN, Luiz Carlos. Chanchada da Atlântida chega ao DVD. O Estado de S.Paulo, Caderno 2, p. c-3, São Paulo, out., 2001.

CARLOS MERTEN, Luiz. “Moacyr Fenelon pede passagem para a Atlântida”. In: 0 Estado de S.Paulo, Caderno 2, p. c-2, mar., 2001

METZ, Christian. A significação no cinema. São Paulo: Perspectiva, 1972.

. “A grande sintagmática do filme narrativo”. In: Análise estrutural da narrativa: pesquisas semiológicas. $3^{\text {a }}$ ed. Petrópolis, Rio de Janeiro: Vozes, 1973. - L'enonciation impersonelle ou le site du film. Paris, Meridianes-Klinsieck, 1991.

MORAES, Fernando. Chatô: o rei do brasil, a vida de Assis Chateaubriand. São Paulo: Companhia das Letras, 1994.

Orlandi, Eni Puccinelli. Análise do discurso: princípios e procedimentos. $4^{\mathrm{a}}$ ed. Campinas, SP: Pontes, 2002.

ORTIZ, Carlos. Carlos Ortiz e o cinema brasileiro na década de 50. São Paulo: IDART / Arquivo de Multimeios, 1981. 
ORTIZ, Renato. Cultura brasileira e identidade nacional. $5^{a}$ ed. São Paulo: Brasiliense, 1994.

. A moderna tradição brasileira. São Paulo: Brasiliense, 2001.

PÊCHEUX, Michel. Semântica e discurso: uma crítica à afirmação do óbvio. Trad. Eni Orlandi et al. Campinas: Editora da Unicamp, 1988.

- “Análise automática do discurso (AAD-69). In: GADET, F. e HAK, T. (Org.). Por uma análise automática do discurso: uma introdução à obra de Michel Pêcheux. Trad. Bethania Mariani et al. Campinas: Editora da Unicamp, 1990.

. “A análise do discurso: três épocas”. In: GADET, F. e HAK, T. (Org.).

Por uma análise automática do discurso: uma introdução à obra de Michel Pêcheux. Trad. Bethania Mariani et al. Campinas: Editora da Unicamp, 1990.

“Papel da memória”. In: Papel da memória. Trad. e introdução J. Horta Nunes. Campinas: Pontes, 1999.

PIPER, Rudolf. Filmusical brasileiro e chanchada. São Paulo: Global, 1977.

REIS, Carlos. Técnicas de análise textual: introdução à leitura crítica do texto literário. Coimbra: Livraria Almedina, 1976.

e LOPES, Ana Cristina M. Dicionário de narratologia. (4 $4^{\mathrm{a}}$ ed.). Coimbra:

Livraria Almedina, 1994.

Revista do Rádio, n 517, 16/8/1959.

ROCHA, Glauber. Revisão crítica do cinema brasileiro. Rio de Janeiro: Civilização Brasileira, 1963.

Revolução de Cinema Novo. Alhambra/Embrafilme, Rio de Janeiro, 1981.

ROSENFELD, Anatol. O teatro épico. São Paulo: Perspectiva, 1997.

SALLES GOMES, Paulo Emilio. Cinema: trajetória no subdesenvolvimento. Rio de Janeiro: Paz e Terra/Embrafilme, 1980.

SENRA, Stella. O último jornalista: imagens de cinema. São Paulo: Estação Liberdade, 1997.

SODRÉ, Nelson Werneck. História da Imprensa no Brasil. $4^{\mathrm{a}}$ ed. rev. Rio de Janeiro: Mauad, 1999. 
SOUZA, Geraldo Tadeu. Introdução à teoria do enunciado concreto do círculo Bakhtin/Volochinov/Medvedev. 2a ed. São Paulo: Humanitas/FFLCH/USP, 2002. SOUZA, Suzana Cristina de. 0 cinema carioca nos anos 30 e 40: os filmes musicais nas telas da cidade. São Paulo: Annablume, 2000.

SPINK, Mary Jane (org.). Práticas discursivas e produção de sentidos no cotidiano: aproximações teóricas e metodológicas. In: “Produção de sentidos no cotidiano: uma abordagem teórico-metodológica para análise das práticas discursivas”. São Paulo: Cortez, 1999.

STAM, Robert. Bakhtin: da teoria literária à cultura de massa. São Paulo: Ática, 2000.

THOMPSON, John B. Ideologia e cultura moderna. Petropolis: Vozes, 1995.

A mídia e a modernidade: uma teoria social da mídia. Petrópolis, RJ: Vozes, 1998.

VANOYE, Francis e GOLIOT-LÉTÉ, Anne. Ensaio sobre a análise fílmica. Trad. Marina Appenzeller. Campinas, SP: Papirus, 1994.

VERNET, Marc. “Cinema e narração”. In: A estética do filme. AUMONT, J. et al. Trad. Marina Appenzeller. Campinas, SP: Papirus, 1995.

VIANY, Alex. Introdução ao cinema brasileiro. $2^{\text {a }}$ ed. Rio de Janeiro: Alhambra/Embrafilme, 1987. Ática, 1992.

VIEIRA, João Luiz. “A chanchada e o cinema carioca (1930-1955)”. In: Ramos, Fernão (org.). História do cinema brasileiro. São Paulo: Art Editora, 1987, p. 131-187.

. "From High Noon to Jaws: Carnival and parody in Brazilian Cinema". In: Robert Stam; Randal Johnson (Orgs.). Brazilian Cinema (expanded edition). 3 ed. New York: Columbia University Press, 1995, p. 256-269.

. Bakhtin: da teoria literária à cultura de massa. São Paulo: Ática, 2000. XAVIER, Ismail. Alegorias do subdesenvolvimento: Cinema Novo, Tropicalismo, Cinema Marginal, 1983.

(org.). A experiência do cinema. Rio de Janeiro: Graal, 1983. (org.). O cinema no século. Rio de Janeiro: Graal, 1983.

. "Do texto ao filme: a trama, a cena e a construção do olhar no cinema". In: Literatura, cinema e televisão.

Tânia Pellegrini... [et al.]. São Paulo: Senac São Paulo / Instituto Itaú Cultural, 2003. 


\section{FILMOGRAFIA}

\section{CARNAVAL NO FOGO}

Rio de Janeiro, 1949, $35 \mathrm{~mm}$.

Cia. produtora: Atlântida - Empresa Cinematográfica do Brasil; Distribuição: Columbia Pictures; UCB (União Cinematográfica Brasileira); Argumento: Anselmo Duarte; Roteiro: Watson Macedo; Alinor Azevedo; Direção: Watson Macedo; Direção de fotografia: George Dusek; Cinegrafista: George Dusek; Pedro Torre; Sonografia: Sílvio Rabello; Arranjos musicais: Panicalli.

Elenco/personagens: Oscarito (Serafim); Grande Otelo (Empregado do hotel); Anselmo Duarte (Ricardo); José Lewgoy (Anjo); Modesto de Souza (Empregado do hotel); Rocir Silveira; Adelaide Chiozzo; Jorge Goulart; Marion; Elvira Pagã; Ruy Rey e sua orquestra; Vocalistas Tropicais; Cuquita Carballo; Eliana (Marina); Geraldo Gamboa (Bandido medroso); Francisco Dantas (Capanga); Navarro de Andrade.

Músicas: Marcha do gago (Klecius Caldas e Armando Cavalcanti); Intérprete: Oscarito; Sangue e areia (Nelson Teixeira e Sebastião Gomes); Intérprete: Elvira Pagã; $A i$, ai, brotinho (Humberto Teixeira); Intérprete: Francisco Carlos; 
Serpentina (Haroldo Lobo e David Nasser); Intérprete: Jorge Goulart; Balzaquiana (Nássara e Wilson Batista); Intérprete: Jorge Goulart; Daqui não saio (Paquito e Romeu Gentil); Intérprete: Vocalistas Tropicais;

Canções: Traga o meu pandeiro; Intérprete: Marion; Pedalando (Benê Nunes e Anselmo Duarte); Intérprete: Adelaide Chiozzo; Naná (Rutinaldo e Ruy Reys); Intérprete: Ruy Reys; Tico-tico no fubá (Zequinha de Abreu); Intérprete: Eliana; Me deixa em paz (Luiz Gonzaga e H. Teixeira); Intérprete: Francisco Carlos; Jealousy (Jacob Gade); Intérprete: Eliana; Benê Nunes e sua Orquestra; Dice mi gallo (Juan Fernandéz); Intérprete: Cuquita Carballo.

\section{ESTOU AÍ?}

Rio de Janeiro, 1949, $35 \mathrm{~mm}$.

Cia. produtora: Cine Produções Fenelon; Cinédia; Produção: Moacyr Fenelon; Distribuição: Cinédia; Argumento: José Rodrigues; Cajado Filho; Diálogos: Cajado Filho; Ítalo Jacques; Estória: José Rodrigues; Direção: Cajado Filho; Coreografia: Cisne Branco; Pedro Dias; Direção de fotografia: A. P. Castro; Direção de som: Luiz Braga Filho; Direção musical: Guerra Peixe.

Elenco/personagens: Emilinha Borba (Prima que deseja ser artista); Colé (Falso empresário); Pedro Dias (Tio de Cuiabá); Celeste Aída (Sua mulher); Ronaldo Lupo (Diretor de rádio); Áurea Paiva (Galho de Colé); Zizinha Macedo (Tia); 
Cahué Filho (Malandro carioca); Duarte Moraes (Paquera de Izaurinha); Izaurinha Garcia; Déo Maia; Lêda Barbosa (Cigana); Zilah Fonseca; Ciro Monteiro; Nelson Gonçalves; Os Cariocas; Bob Nelson; Trio Guarás; Eva Lanthos; Floripes Rodrigues; Roberto; Irene; Paulo Molin; Luiza Mafra (dançarina de frêvo).

Músicas: Sem ela (Hugo Roberto e Ary Monteiro); Intérprete: Cyro Monteiro; Tem branco na maloca (Valente de Assis); Intérprete: Zilah Fonseca; Porta bandeira (Nássara e Antonio Almeida); Intérprete: Emilinha Borba; Chiquita bacana (João de Barros e Alberto Ribeiro); Intérprete: Emilinha Borba; De conversa em conversa (Lúcio Alves e Haroldo Barbosa); Intérprete: Isaurinha Garcia; Adeus América (H. Barbosa e Geraldo Jacques); Intérpretes: Trio Guarás; Vaqueiro no samba (Rosalino Senos e Irany Oliveira); Intérprete: Bob Nelson; Pra quê? (Celso Monteiro e Djalma Esteves); Intérprete: Deo Maia; Bailado espanhol; Intérpretes: Roberto e Irene; Pepita (Roberto Roberti e Arlindo Marques); Intérpretes: Nelson Gonçalves; Esther Tarcitano; Isabel; Yvette Simões e Alair; Está quase na hora (Pedro Caetano e Alcir Pires Vermelho); Intérpretes: Leda Barbosa e Eva Lanthos; Namoro a esparadrapo (Guerra Peixe); Intérprete: Luiza Mafra; Tem marujo no samba (João de Barros); Intérprete: Emilinha Borba; Cisne branco (Antonio Espírito Santo); Intérprete: Emilinha Borba; Meu coração vai chorar (Lazzoli e Dias da Cruz); De junho a dezembro (Jair Amorim e Nelson de Seixas); Intérpretes: Cyro Monteiro e Floripes Rodrigues; Música de: Luiz Gonzaga; Humberto Teixeira; Assis Valente; Iracy de Oliveira; Celio Monteiro. 


\section{AGÜENTA FIRME, IZIDORO}

Rio de Janeiro, 1950, 35 mm, 65 min.

Cia. produtora: Estúdios Cinédia; Produção: Adhemar Gonzaga; Co-produção: Luís Marques de Araújo; Distribuição: Art Films; Argumento: Gita de Barros; Roteiro: Adhemar Gonzaga; Direção: Adhemar Gonzaga; Continuidade: Yolanda Fronzi; Direção de fotografia: Maurice Pecqueux; Sonografia: Ercole Baschera; Edição: Luiz de Barros; Dir. Arte/Cenografia: Luiz de Barros; Trilha musical: Arturo Usai;

Elenco/personagens: Totó (Izidoro e Pedrito Molina); Nelma Costa (Rita Molina); Deleo Jr. (Dr. Jayme Peixinho); Zaquia Jorge (Cartomante); Zé Trindade (Vizinho que desmaia, no apartamento de Izidoro); José Mafra (De óculos leve, no apartamento de Izidoro); Adolar Costa (De óculos leve, no apartamento de Izidoro); Violeta Ferraz (Dona Mariquinhas); Jacy de Oliveira (Empregada de Izidoro); Marilu Dantas (Empregada da pensão); Nilza Ferreira (Rumbeira); Wellington Botelho (Queixoso, preso na delegacia); Carlos Barbosa ( $\mathrm{Na}$ delegacia); Augusto Annibal (Guarda de prontidão); Alexandre Alencastro (Médico); Leonel Saraiva ( $\mathrm{Na}$ boate, de piteira na mão); Oswaldo Loureiro ( $\mathrm{Na}$ boate, terno marrom listrado); Joe Lester (Guarda); Maria (Com colares brancos); Yolanda Fronzi (Mulher que segura o bebê); Walter de O. Villas (Locutor); Mário Alcoforado (Locutor); Claudete de Souza Aguiar (Recém-nascido); José Ferreira (Empregado do edifício); Dedé Martins Pinheiro (Moradora do prédio); Mário 
Costa (Padeiro na entrada do prédio); Newton Reis da Fonseca (Guarda na entrada do prédio); Ilídio Costa (Bicheiro, no botequim); Carlos Freitas Rodrigues (Agente de polícia); Gastão André (Comissário de polícia); Anna Filomena Matuleone (Girl no teatro); Carmem Laman (Girl no teatro); Hilda Jaanikz (Girl no teatro); Neyde Lamar (Girl no teatro); Madame Lou; Maury da Rosa e Silva; Feliz Baptista; Luiz Piccini; João Rodrigues (Agente de polícia no botequim); José Queiroz (No teatro); Olga Queiroz (No teatro); Jerônimo Peres (Contra-regra); Jorge Dias Ferreira (Porteiro do teatro); José Ferreira (Porteiro do teatro); Afrânio Acioly Oliveira (Menino na pensão de D. Mariquinhas); Edmundo C. de Almeida (Menino pega ladrão, roubo da bolsa); Isabel de Almeida (Mulher da bolsa); Antonio Fernandes (na entrada do edifício); Oswaldo Mandarino (na entrada do edifício); José Monteiro de Carvalho (na entrada do edifício); Itamar Monteiro Oliveira (No apartamento de Izidoro); Rosita Grey (No apartamento de Izidoro); Ludmilla Rybalowski (No apartamento de Izidoro); Edemmee Cavalcanti (No apartamento de Izidoro); Mme. Vanja (No apartamento de Izidoro); Orlando Mendonça (Guarda na $1^{\text {a }}$ delegacia); José Izidoro (Garçom "malhado" no botequim); Oldemar Pinheiro (No botequim); Antonio Correa (No botequim).

Canções: Um Pedaço do Brasil (Luiz Antonio e J. Jr.); Intérprete: Helena de Lima; O Badala (Zerém e Guará); Intérprete: Aracy Costa; Mi comparsa linda (Don Valdrico); Intérprete: Sil Mary; Orquestra: Orquestra de Don Valdrico; 
Conjunto e banda: Trio de Ouro; Intérprete: Linda Baptista; Orquestração: Três Marias.

\section{CARNAVAL ATLÂNTIDA}

Rio de Janeiro, 1952, 35 mm, $92 \mathrm{~min}$.

Cia. produtora: Atlântida - Empresa Cinematográfica do Brasil;Gerente de produção: Guido Martinelli; Distribuição: UCB (União Cinematográfica Brasileira); Argumento: Jr. Berliet; Victor Lima; Roteiro: José Carlos Burle; Jr. Berliet; Victor Lima; Estória: Estória de Jr.Berliet e Victor Lima; Direção: José Carlos Burle; Continuidade: Arlete Lester; Coreografia: Juliana Yanakiewa; Direção de fotografia: Amleto Daissé; Técnico de som: Aloisio Viana; Jesus Narvaez; Ercole Baschera; Montagem: Wilson Monteiro; Dir. Arte/Figurinos: Gilda Bastos; Osvaldo Mota; Cenografia: Martim Gonçalves; Pablo Olivo; Direção musical: Lirio Panicalli; Instrumentista: Dinarte; Partitura musical: Lirio Panicalli.

Elenco/personagens: Oscarito (Prof. Xenofontes); Grande Otelo(Assistente de estúdio); Cyll Farney (Augusto); Eliana (Regina); José Lewgoy (Conde Verdura); Colé (Empregado do estúdio); Renato Restier(Cecílio B. de Milho); Wilson Grey(Amestrador de pulgas); Iracema Vitória (Aurélia); Carlos Alberto; Blecaute; Francisco Carlos; Bill Farr; Nora Ney; Dick Farney; Orquestra de Chiquinho; Colé (Pedro); Aurélio Teixeira; Jesus Ruas; Leonel Saraiva; Rosa Sandrini; Victor Binot; 
W.Hanner; Aurelina Lisboa; Argentina Della Torre; Edith Tremonte; Edmundo Carlo; Ingrid Germer; Isaura Henriques; Marlene Barroso; Maurício Loyola; Moacir Ferreira; Núcia Miranda; Oscar B. Freitas; Participação especial: Maria Antonieta Pons (Lolita).

Canções: Dona cegonha (Armando Cavalcanti e Klecius Caldas); Intérprete: Blecaute e Maria Antonieta Pons; No tabuleiro da baiana (Ari Barroso); Intérprete: Grande Otelo e Eliana; Quem dá aos pobres (Klecius Caldas e Armando Cavalcanti); Intérprete: Francisco Carlos; Vai nascer sapinho (Humberto Teixeira e Norte Victor0; Intérprete: Oscarito e Maria Antonieta Pons; A Marcha do conselho (Paquito e Romeu Gentil); Intérprete: Bill Farr e Orquestra de Chiquinho; Mambo caçula (Benício Macedo e Beré Alexandre); Intérprete: Maria Antonieta Pons; Cachaça (Mirabeau Pinheiro; Lucio de Castro e Heber Lobato); Intérprete: Grande Otelo e Colé; Ninguém me ama (Antônio Maria e Fernando Lobo); Intérprete: Nora Ney; Dick Farney; José Lewgoy e Iracema Vitória; Alguém como tu (José Maria de Abreu e Jair Amorim); Intérprete: Dick Farney; Máscara da face (Armando Cavalcanti e Klecius Caldas); Intérprete: Maria Antonieta Pons; Valsa da formatura (Lirio Pnicalli e Claribalte Passos); Orquestra de Chiquinho; Baião (Humberto Teixeira e Luiz Gonzaga); Orquestra de Chiquinho; Queria ser patroa (M.Pinto e Airão); Eliana e Orquestra de Chiquinho; Frevo vassourinha n. 1; Intérprete: Eliana; Bigode de gato (Jesus Guerra); Cuquita Carballo; Acho-te uma graça (Benedito Lacerda); Haroldo Lobo e Carvalhinho; Agora é cinza (Alcebíades Barcellos e Armando Marçal); Ai que 
saudades da Amélia (Ataulpho Alves e Mário Lago); É bom parar (Rubens Soares); Rasguei a minha fantasia (Babo, Lamartine); Serpentina (Haroldo Lobo e David Nasser); O Teu cabelo não nega, mulata (Lamartine Babo); João Valença e Raul Valença; O Domingo no Jardim de Allah (Lírio Panicalli e Ewaldo Ruy); Pastorinhas (Noel Rosa e João de Barro); Pirata (João de Barro e Alfredo Ribeiro); Se a lua contasse (Custódio Mesquita); Um Pierrot apaixonado (Heitor dos Prazeres e Noel Rosa); Praça 11 (Herivelto Martins e Grande Otelo).

\section{CARNAVAL EM CAXIAS}

Rio de Janeiro, 1953, 35 mm, $80 \mathrm{~min}$.

Cia. produtora: Flama Filmes; Produção: Murilo Berardo; Jorge Ileli; Diretor de produção: Guido Martinelli; Distribuição: UCB (União Cinematográfica Brasileira) ; Argumento: Leon Eliachar; Paulo Vanderley; Jorge Ileli; Alex Viany; Roteiro: Leon Eliachar; Paulo Vanderley; Jorge Ileli; Alex Viany; Direção: Paulo Vanderley; Coreografia: Wladimir Irman; Direção de fotografia: Ferenc Fekete; Direção de som: Luiz Braga Jr.; Montagem: Rafael Justo Valverde; Dir. arte/Cenografia: Martim Gonçalves; Música: Radamés Gnatalli.

Elenco/personagens: José Lewgoy (Honório Boa Morte); Doris Monteiro (Garçonete do sallon); Modesto de Souza (Prefeito de Caxias); Josette Bertal (Estrela do Cabaret); Ariston (Irmãos Dione); Consuelo Leandro (Filha do prefeito); Jece Valadão (Camelô e locutor); Nelson Dantas (Homem do bar); 
Jesus Ruas (Juiz); Aurélio Teixeira; Wilson Grey; José Melo; Valdo César; Mário Japa; Benedito Rodrigues; Armando Camargo; Dalwan Lima; Nelson Soares; Jefferson Dantas.

Canções: Se eu fosse Getúlio (Peter Pan); Dor de cotovelo (Aylce Chaves); Mulher que é mulher (Luiz Souza); Seu Honório (Paulo Marques); Lama ( João R. Kelly); Que saudade é esta ( Marcílio Vieira); Marcha da Penicilina (José Marcílio); Miguel é o maior (Klécius Caldas); Em Mangueira eu nasci (Hervê C.)Abre alas ( Armando Cavalcanti); Intérpretes: Iracema Vitória; Nelson Gonçalves; Dircinha Batista; Linda Batista; Nora Ney; Jorge Goulart; Carmélia Alves; Bené Nunes e sua Orquestra.

Prêmios: Melhor Argumento para Alex Viany e Leon Eliachar, Melhor Edição para Rafael Justo Valverde, Prêmio O Índio, 1954, Revista Jornal do Cinema, RJ.

\section{CARNAVAL EM MARTE}

Rio de Janeiro, 1954, 35 mm, 90 min.

Cia. produtora: Brasil Vita Filmes; Produção: Watson Macedo; Direção de produção: Murillo Lopes; Distribuição: Cinedistri - Companhia Produtora e Distribuidora de Filmes Nacionais; Unida Filmes; Argumento: Watson Macedo; Roteiro: Watson Macedo; Anselmo Duarte; Diálogos: Alinor Azevedo; Leon Eliachar; Direção: Watson Macedo; Continuidade: Geny Macedo; Coreografia: 
Norbert Nardone; Direção de fotografia: Edgar Eichhorn; Giulio de Luca; Direção de som: Alberto Viana; Montagem: Watson Macedo; Anselmo Duarte; Dir. Arte/Figurinos: Elia M. de Souza; Oswaldo Mota; Cenografia: Gabriel Queiroz; Ayres Baldissara; Eudoro Pacheco; Música: Alexandre Gnatalli.

Elenco/personagens: Violeta Ferraz (D. Petrolina); Catalano (Catarino); Pituca; Silva Filho (Chaveco); Zezé Macedo (Justina); Oswaldo Elias; Armando Couto; Déo Maia; Edmundo Maia; Benedito Rodrigues; Vicente Marchelli; Walter Sequeira; Sylvia Telles; Selma Duval; Neida Marim; Alberto Curi; Pina Bruneti; Anselmo Duarte (Ricardo); Ilka Soares (Lidia).

Canções: Não vou morrer (Haroldo Lobo e Milton de Oliveira); Judas (Haroldo Lobo e David Nasser); Tem nego bebo aí (Mirabeau Ayrton Amorim); Se você pensa (Cesar de Alencar); No Japão é que é bom (Haroldo Lobo e Milton de Oliveira); Ninguém tem pena (Haroldo Lobo e Milton de Oliveira); A Água lava tudo (Paquito; Romeu Gentil e R. Gonçalves); Pé na tábua (Heraldo Medeiros); Tens que penar (Almeidinha; A. Lourenço e Peri Rib); Enchente da maré (J.Filho e Uzema); Jogado fora (Ruy Rei e Dunga); Deixa (Norival Reis e José Batista); Rio e amor (Bruno Marnet); Carnaval (Djalma Ferreira); Intérpretes: Angela Maria; Jorge Veiga; Linda Batista; Cauby Peixoto; Emilinha Borba; Cesar de Almeida e Carmem Costa. (Araci Costa); Intérpretes: Jorge Goulart; Ruy Rei e sua Orquestra; Bandeirante e seus Melódicos; Rey Tabajara do Brasil; Real Clube Escola; Império do Frêvo; Escola de Samba da Mangueira e Estação Primeira. 
NEM SANSÃO NEM DALILA

Rio de Janeiro, 1954, $35 \mathrm{~mm}, 90 \mathrm{~min}$.

Cia. produtora: Atlântida - Empresa Cinematográfica do Brasil; Direção de produção: J. B.Tanko; Gerente de produção: Victor Lima; Distribuição: UCB (União Cinematográfica Brasileira; Argumento: Victor Lima; Roteiro: Victor Lima; Direção: Carlos Manga; Coreografia: Blanche Mur; Continuidade: Arlete Lester; Direção de fotografia: Amleto Daissé; Direção de som: Aloysio Vianna; Montagem: Waldemar Noya; Carlos Manga; Dir. Arte/Cenografia: Cajado Filho; Música: Luís Bonfá; Partitura musical: Lirio Panicalli.

Elenco/personagens: Oscarito (Horácio e Sansão); Fada Santoro (Miriam); Cyll Farney (Hélio); Eliana (Dalila); Carlos Cotrim (Artur e chefe da guarda); Wilson Grey (Rei Anateques e médico); Wilson Viana (Chico Sansão); Ricardo Luna (Jebor e chofer); Werner Hammer (Professor Incognitus); Anthony Zamborsky (Elestal, o sacerdote); Sérgio de Oliveira (Zubal); João Péricles (Inspetor de tráfego); Gene de Marco (Zorina); Milton Leal (Carrasco e padioleiro); Carlos Mesnik (Carrasco e padioleiro); José do Patrocínio (Eunuco); Jorge Luiz (Eunuco).

Prêmios: Prêmios de Melhor ator para Cyll Farney e de Melhor Ator Secundário para Wilson Grey, O Índio, 1954, Revista Nacional do Cinema - RJ. 


\section{CARNAVAL EM LÁ MAIOR}

São Paulo, 1955, 35 mm, 90 min.

Cia. produtora: Cinematográfica Maristela; Cia. co-produtora: Cinédia Produção: Mário Audrá Jr.; Direção de produção: Alfredo Palácios; Distribuição: UCB (União Cinematográfica Brasileira); Argumento: Adhemar Gonzaga; Osvaldo Moles; Roteiro: Adhemar Gonzaga; Osvaldo Moles; Diálogos: Adhemar Gonzaga; Direção: Adhemar Gonzaga; Continuidade: Yolanda Fronzi; Direção de fotografia: Ferenc Fekete; Direção de som: Sérgio Alvarez; Montagem: José Cañizares; Edição: José Cañizares; Dir. Arte/Cenografia: Carlos Jiacheri; Música de: Gabriel Migliori.

Elenco/personagens: Walter d' Avila (Moreira); Sandra Amaral (Celina); Randal Juliano (Eleoberto); Caetano Gherardi (Apaixonado de Celina); Elisio de Albuquerque (Amigo de Eleoberto); Jane Batista (Loura de calça comprida); Caco Velho (Faxineiro na agência de turismo); João Soares (Passageiro com charuto e pasta); Carlos Assumpção; Cid Pais de Barros; Luiz Boronini; Anette Monteiro; Zé Bacuráu; Adoniran Barbosa(Judeu verdedor de móveis); Blota Jr. (Diretor da televisão); Durval de Sousa (Secretário); Nestorio Lipps (Louro de terno escuro); Carlos Araújo (Mamão macho); Aparecida Baxter (Mãe de Celina); Valery Martins (Dona da pensão); Mario Sena; Gilberto Chagas (Cozinheiro); Pimentão (Cozinheiro); Celina Amaral; Guaracy Maia(Morador da pensão); Luiza de Oliveira 
(Passageira com lenço no cabelo); Bob Junior; Genésio Arruda (Caipira na estação); Vicente Leporace (Passageiro na perua); Carmen Silva (Morena de chapéu com capa de chuva no braço); Oswaldo de Barros (Passageiro do avião com guarda-chuva); Cesar Medeiros; Idalina Oliveira (Moça na mesa na boate); Rosa Maria; Moneti Mendes; Alfredo Simoney; Arrelia (Cozinheiro); Assis (Maitre Menatti); José Mercaldi (Garçon da boate); Ivonette (Moça na agência de turismo); Emilio Dumas (Delegado); Roberto Mackim (Português com pasta); José Júlio Spiewack (Mordomo); Albertina (Ofélia); Arnaldo Weiss (Hamlet); Dirce Pires (Mulher fantasiada); Pisani Pisani (Pintor); Ary Leite (Morador da pensão); Cândido Banzatto (Diretor da agência funerária); Walter Duarte (Controlador da estação de TV); Felippe Ricci (controlador da estação de TV); José Vedovato; Edmar Sales; Luís Dias; Aracy de Almeida; Hervê Cordovil; Participação especial: Renata Fronzi (Lola).

Canções: Prece ao vento(Alcyr Pires Vermelho; Fernando Luís e Gilvan Chaves); Intérprete: Trio Nagô; Vamos falar de saudades (Mário Lago e Chocolate); Intérprete: Nora Ney; Seresteiros (Renato Lima); Intérprete: Tufik Lauar e Zé Keti; Joga fora o meu pandeiro (Nelson Gonçalves; Adelino Moreira e Jarbas Reis); Intérprete: Nelson Gonçalves; Soluço; Intérprete: Alvarenga e Ranchinho II; Banco de jardim (Edair Badaró e Bob Jr); Disco voador (Hervê Cordovil); Intérprete: Carmélia Alves; Os Estatutos da gafeira (Billy Blanco); Intérprete: Inezita Barroso; Pé de pobre (Alfredo Borba; A. Barbosa e José Roy); Intérprete: Elza Laranjeira; Rabo de saia (A. Alves e J. Castro); Intérprete: Ataulfo Alves e 
suas Pastoras; Saúva (Roberto Roberti e Arlindo Marques Jr); Ressaca (Zé da Zilda); Intérprete: Jorge Goulart; Retirantes (Luiz Vieira e Ubirajara Santos); Intérprete: Mario Senna; Fala-me de amor (Jorges Moran e Osvaldinho); Paulista de Mato Grosso (V. Simon e F. Martins); Intérprete: Vagalumes do Luar; Zé Praxedes (Zé Ramos e Juca do Acordeon); Dá licença (Mário Vieira e Henricão); Intérprete: Oswaldo Rodrigues; Meu primeiro amor (Herminio Gimenez; Pinheiro Jr. e José Fortuna); Intérprete: Cascatinha e Inhana; O Girassol e o jardim (Denis Brean e Nilo Silva); Carro de bigode (Filinho e Thalma de Oliveira); É pecado (Leitão Doca e Eunice); Intérprete: Ester de Souza; Outro caminho (Cezar Cruz e José Rosas); Dois violeiros no terreno de pouso; Intérprete: Alvarenga e Ranchinho; João, Isto é papel? (Paulo Ruschell); Intérprete: Aracy de Almeida; O Coco; Intérprete: Carlos Galhardo; Carro de bigode (Filinho e Thalma de Oliveira); Intérprete: Isaurinha Garcia; Na boate; Intérprete: Jimmy Lester. - Gatinho; Intérprete: Randal Juliano e Sandra Amaral.

Prêmios: Prêmio Saci, 1955, SP, Prêmio Revelação para Sandra Amaral.

\section{VAMOS COM CALMA}

Rio de Janeiro, 1955, $35 \mathrm{~mm}, 98 \mathrm{~min}$.

Cia. produtora: Atlântida - Empresa Cinematográfica do Brasil; Produção: Guido Martinelli; Distribuição: UCB (União Cinematográfica Brasileira); Argumento: Luís Iglésias; Miguel Santos; Roteiro: Carlos Manga; José Cajado Filho; Estória: 
Baseada na peça teatral “Cabeça de porco" de Luís Iglésias, e Miguel Santos;

Direção: Carlos Manga; Coreografia: Norbert Nardone; Continuidade: Arlete Lester; Direção de fotografia: Amleto Daissé; Direção de som: AloysioVianna; Montagem: Carlos Manga; Edição: Waldemar Noya; Dir. Arte/Cenografia: Wilson Monteiro; Benedito Macedo; Música: Guio de Morais.

Elenco/personagens: Oscarito (Buscapé); Eliana Macedo (Sandra); Cyll Farney (Luís Carlos); Margot Louro (Mme. Pixoxó); Ivon Curi (Príncipe Nico); Wilson Grey; Wilson Viana; Derek Wheatley; Maurício Sherman; Cesar de Alencar; Moacir Deriquem; Ataulfo Alves; Bill Farr; Blecaute; Emilinha Borba; Ester de Abreu; Francisco Carlos; Isaurinha Garcia; Jorge Goulart; Jupira; Nora Ney; Ruy Rey; Venilton Santos; Orquestra Fernando Azevedo; Orquestra Ruy Rey; Heleninha Costa; Marilena Cairo; Ed Liconln; Lourdes Freire; Aracy Rosas; Guio de Morais; Apresentando: Avany Maura (Carmen).

Música: Tema de Paganini; Intérprete: Geraldo Rocha; Orquestração: Guio de Morais. Canções: Pescador granfino (João de Barro); Ai Maria (Norival Reis; Ruy Rey e Antonio de Almeida); Palavra de rei (Ataulfo Alves); Fala Mulato (Alcebíades Nogueira e Ataulfo Alves); Olha a água (Estanislau Silva e Gil Lima); Festa do Samba (Denis Brean e Osvaldo Guilherme); Maria Champanhota (Klecius Caldas e Armando Cavalcanti); Amar é sofrer (Billy Blanco); Samba no Havai (Irany de Oliveira e Bruno Marmet); Era de madrugada (Paquito; Romeu Gentil e Boexi); O que Deus me deu (Paquito; Romeu Gentil e Airton Amorim); Sorriu para 
mim (Garoto e Luiz Claudio); Ressureição (Blecaute); Vem à janela (Claudionor Santos e Ivo Santos); É o fim (Ivo Curi); Que sabe, sabe (Sandoval Jota e Carvalhinho); Vou me acabar (Ricardo Galeno); Porque choras (Claudionor Santos e Maria Pereira); Amendoim torradinho (Henrique Beltrão); De hora em hora (Norival Reis; Antonio de Almeida e Rui Rey); Marcha do faquir (Haroldo Lobo e Branzinha); No baile dos casados (Alvaro Martins; Aristides Filho e Arnaldo Morais).

\section{COM ÁGUA NA BOCA}

Rio de Janeiro, 1956, $35 \mathrm{~mm}, 90 \mathrm{~min}$.

Cia. produtora: Herbert Richers - Produções Cinematográficas; Direção de produção: Eurico Richers; Distribuição: Herbert Richers - Sonofilmes; Argumento: J. B. Tanko; Renato Restier; Roteiro: J. B. Tanko; Renato Restier; Direção: J. B. Tanko; Coreografia: Helba Nogueira; Direção de fotografia: Amleto Daissé; Sonografia: Nelson Ribeiro; Montagem: Rafael Justo Valverde; Dir. Arte/Cenografia: Nicolas Lounine; Alexandre Horvat; Arranjos/ Partituras musicais: Renato de Oliveira.

Elenco/personagens: Carequinha (Carequinha); Fred Vilar (Fred); Renato Restier (Dr. Satã); Costinha (Bonifácio); Anilza Leoni (Marina); Adalgisa Colombo (Terezinha); Alberto Peres (Milton); Procopinho (Prudêncio); Yara Jety (Maria da Glória); Otelo Zeloni (Diretor da TV); Jorge Petroff; Madame Lou (Mme. Malut); 
Antônio Garcia; Cazarré Filho; Dracon; Laura Patrícia; Rosa Sandrini; Aldo Nélio; Rosita Lopes; Angela Maria; Cauby Peixoto; Lidia Reis; Orlando Guy; Os Três Rubis; Jupira e suas Cabrochas; Sarrafo.

Canções: Com água na boca (Assis Valente); Intérprete: Elenco do filme; Me leva (Assis Valente); Conj. e banda: Os Três Rubis, Jupira e suas Cabrochas; Ai, sa moça (Assis Valente); Intérprete: Anilza Leoni; U-la-la (Assis Valente); Intérprete: Madame Lou e Carequinha; Mentindo (Eduardo Patané e Lourival Faissal); Intérprete: Angela Maria; Conceição (Dunga e Jair Amorim); Intérprete: Cauby Peixoto;

Prêmios: Prêmio de Melhor Atriz para Anilza Leone, Festival do Distrito Federal, 4/4/1956, RJ.

\section{RIO FANTASIA}

Rio de Janeiro, 1956, $35 \mathrm{~mm}, 115 \mathrm{~min}$.

Cia. produtora: Produções Watson Macedo; Produção: Watson Macedo; Direção de produção: Elias Lourenço Souza; Distribuição: Cinedistri; Argumento: Watson Macedo; Roteiro: Ismar Porto; Riva Farias; Diálogos: Ismar Porto; Riva Farias; Direção: Watson Macedo; Continuidade: Geny Macedo; Direção de fotografia: Mário Pagés; Direção de som: Spiros Saliveros; Montagem: Mauro Alice; Dir. Arte/Figurinos: Elia Macedo; Maria Oliveira; Música: Lirio Panicalli. 
Elenco/personagens: Eliana (Lia); John Herbert (Carlos); Renato Murce (Freitas); Humberto Catalano (Leônidas); Trio Ikaritan; Rosa Sandrini; Zezé Macedo (Empregada da pensão); Madame Lou; Oswaldo Louzada; Elba Nogueira; Francisco Moreno; Guilherme Natalice; Inah Malagutti; Jairo Argileu; Eli Augusto; Francisco Sanatori; Império do Frevo; Rei Tabajara do Brasil; Álvaro Costa; Flora Almeida; Francisco Seciliano; Luiz Almeida; Margarida Lirio; José Reginaldo; Margarida Abreu; Ventura Ferreira; Turco Fernandinho; Eloá Dias; Angela Maria; João Dias.

Canções: Andorinha preta (Breno Ferreira); Intérprete: Eliana e Trio Irakitan; Ô Lia (Breno Ferreira); Intérprete: Eliana e Trio Irakitan; Forró no Tianguá (João Batista do Vale e Antonio Aguiar); Intérprete: Eliana e Trio Irakitan; Os Quindins de iaiá (Ari Barroso); Intérprete: Eliana e Trio Irakitan; Assim é o meu Rio (Irany Oliveira e Jair de Araújo); Intérprete: Eliana e Trio Irakitan; Salomé (Mario Mascarenhas); Intérprete: João Dias; Mentindo (Eduardo Patané e Lourival Faissal); Intérprete: Angela Maria; Hino ao músico (Dorival Silva e Francisco Anizio); Intérprete: Eliana e Trio Irakitan; Adeus batucada (Synval Silva); Intérprete: Eliana; Baião (Humberto Teixeira e Luiz Gonzaga); Intérprete: Eliana; Fazenda Boa União (Altamiro Carrilho). Instrumentistas: Waldyr Calmon - solo de piano e Luiz Bonfá - solo de violão. Conjuntos e bandas: Império do Frevo; Rei Tabajara do Brasil; Trio Irakitan. 


\section{A BARONESA TRANSVIADA}

Rio de Janeiro, 1957, $35 \mathrm{~mm}, 100 \mathrm{~min}$.

Cia. produtora: Produções Watson Macedo; Produção: Watson Macedo; Direção de produção: Elias Lourenço de Souza; Distribuição: Cinedistri - Companhia Produtora e Distribuidora de Filmes Nacionais; Unida Filmes; Argumento: Watson Macedo; Francisco Anísio; Roteiro: Ismar Porto; Watson Macedo; Diálogos: Watson Macedo; Ismar Porto; Direção: Watson Macedo; Continuidade: Geny Macedo Direção de fotografia: Mario Pagés; Montagem: Mauro Alice; Dir. Arte/Cenografia: C. Moura Eolo; Música: Lírio Panicalli.

Elenco/personagens: Dercy Gonçalves (Baronesa e Gonçalina); Grande Otelo (Benedito); Catalano (Ambrósio); Badaró (Neco); Zaquia Jorge (Suely Borel); Zeloni (Guilhermo Masseratti); Bill Farr (Eduardo); Aída Campos (Marisa); Francisco Dantas (Juvaldo); Rosa Sandrini (Celina); Lourdes Bergman (Zuleika); Silvio Jr.; Domingos Terras (Claudionor); Armando Nascimento(Médico); Renato Consorte (Advogado); Vicente Marchelli (Francisco); Apolo Correia (Sinval); Tiririca (Otoniel); Francisco Martorelli (Mordomo); Antonio Nobre (Especialista de pintas); Lindberg Leite (Homem da casa de penhores); Irismar Motta (Primeiro assistente de diretor); Silvio Fernando (Segundo assistente); Helena Martins (Mulher da primeira pinta); Patrícia Laura (Mulher da segunda pinta); Índia do Brasil (Mulher da terceira pinta); Alvaro Costa (Primeiro urubu); Francisco Seciliano (Segundo urubu); J. Viana (Terceiro urubu); Pedro Farah (Repórter); 
Luiz Almeida (Primeiro policial); Ventura Ferreira (Segundo policial); Átila lório (Amante e ator do drama); Guilherme Natalice (Marido e ator do drama); Marly Almeida (Manicure); Arli Roncato (Eletricista); José Melo ; Irany de Oliveira e seu conjunto Marabá.

Canções: O que é amar (Johnny Alf); Não me jogue fora (Avaré e Aldacir Louro); Vai que depois eu vou (Zé, Zilda, Adriano Barbosa e Aôr Ribeiro); Vamos beber (Paquito, Nelson Boexi e Romeu Gentil); Me leva pra Bauru (Irany de Oliveira).

\section{ABSOLUTAMENTE CERTO}

São Paulo, 1957, 35 mm, 95 min.

Cia. produtora: Cinedistri - Produtora e Distribuidora de Filmes do Brasil; Produção: Oswaldo Massaini; Distribuição: Cinedistri - Produtora e Distribuidora de Filmes do Brasil; Unida Filmes; Argumento: Anselmo Duarte; Roteiro: Anselmo Duarte; Diálogos: Thalma de Oliveira; Estória: Baseada em idéia original de: J. Miguel e Jorge Dória; Direção: Anselmo Duarte; Continuidade: Norberto Nath; Coreografia: Ismael Guizer; Direção de fotografia: Chick Fowle; Animação: Horacio Camargo; Engenharia de som: Bosdan Kostiw; Ernst Hack; Ernst Magassy;Edição: José Cañizares; Dir. Arte/Cenografia: Pierino Massenzi; Orquestra: Maestro Enrico Simonetti. 
Elenco/personagens: Anselmo Duarte (Zé do Lino); Dercy Gonçalves (Dona Bela); Odete Lara (Odete); Aurélio Teixeira (Raul); Maria Dilnah (Gina); José Policena (Pai de Zé do Lino); Luiz Orini (Aurélio); Jaime Barcellos (Capanga); A. Fregolente (Pai de Raul); Carlos Costa (Toneco); Marina Freire (Mme. Clarisse); Murilo Amorim Corrêa (Guilherme); Sergio de Oliveira (Tulio); Luciano Gregory (Luciano Rinaldi); José Mercaldi (Porteiro); Edson França (Revisor); Medeiros Filho (Revisor); Silva, Teotoni Pereira da (Televizinho); Pinheiro, Ceci (Televizinha); Cavagnole Neto (Tipógrafo); Suzi Pinheiro (Mulher de Luciano); Estanislau Furman Filho (Tipógrafo); Ernani Conti (Tipógrafo); Almir Cezar; Esdras Vassalo; Itamar Borges; Valentino Guzzo; Mario Benvenutti; Ovídio Cunha Lobo; Adalberto Maciel; Moacir Mello; Mario Gan; Franklin de Oliveira; Dorita Duarte (Secretária); Pedro Luiz (Locutor esportivo); Nelson de Oliveira (Locutor da boate); Henrique de Paula (Boxeador); Arnaldo Galdi (Boxeador); Jamil Maida (Boxeador); Paulo Victor (Sparring colored); Trio Irakitan; Betinho e seu conjunto; Lyris Castelani; Nilton Rezende; Booker Pittmann; Aloysio Figueiredo; Orlando Pierre; Rubens Morales (Bongozeiro); Ruy Ditore (Bongozeiro); Almir Ribeiro; Participação especial: Paulo de Jesus (Paulo).

Canções: Zezé (Humberto Teixeira e Caribé da Rocha); Intérprete: Trio Irakitan. Enrolando o rock (Betinho e Heitor Carillo); Intérprete: Aurélio Teixeira, Betinho e seu conjunto. Onde estou? (Hervé Cordovil e Vicente Leporace); Intérprete: Almir Ribeiro. Quando eu digo (Billo Frómeta); Intérprete: Odete Lara. Agora é cinza (Alcebiades Barcellos e Armando Vieira Marçal); 
Intérprete: Trio Irakitan. Não tenho lágrimas (Maximiliano Bulhões e Milton de Oliveira); Intérprete: Nilton Rezende. Jura (J. B. da Silva); Intérprete: Dercy Gonçalves.

Prêmios: Prêmio Saci, 1957, SP, de Melhor Roteiro para Anselmo Duarte; de Compositor para Enrico Simonetti. Prêmio Governador do Estado, 1957, SP, de Melhor Ator e de Melhor Roteiro para Anselmo Duarte.

\section{COM JEITO VAI}

Rio de Janeiro, 1957, 35 mm, 93 min.

Cia. produtora: Cinedistri - Produtora e Distribuidora de Filmes do Brasil; Produção: Oswaldo Massaini; Co-produção: Herbert Richers; Distribuição: Cinedistri - Produtora e Distribuidora de Filmes do Brasil; Distribuidora de Filmes Sino; Argumento: Renato Restier; Jr.Berliet; Roteiro: J. B. Tanko; Diálogos: Renato Restier; Jr. Berliet; Direção: J. B. Tanko; Continuidade: Oscar Nelson; Coreografia: Bambi Bramar; Direção de fotografia: Amleto Daissé; Direção de som: Nelson Ribeiro; José Moreira Frade; Montagem: Rafael Justo Valverde; Dir. Arte/Cenografia: Alexandre Horvat; Direção musical: Haroldo Eiras. Orquestra: Lírio Panicalli.

Elenco/personagens: Carequinha e Fred (Carequinha e Fred); Grande Otelo (Feijão); Renato Restier (Sargento Paulo); Costinha (Cabo Tripa); Roberto Duval 
(Sargento Braza); Anilza Leoni (Ângela); Malu (Malú); Nancy Montez (Vedete); Celeste Ainda; Procopinho (Capitão Médico); Perpétuo Silva (Comandante); Armando Nascimento (Empresário); Rodolfo Carvalho (Cabeleireiro); Altair Vilar (Sargento); Chiquinho (Fotógrafo); Antonio Batista Nabor (Mágico); Miriam Reny (Embaixatriz); Maria Muniz (Camareira).

Canções: Com jeito vai (João de Barro); Intérprete: Grande Otelo; Melodia do céu (Haroldo Eiras e Di Veras); Intérprete: Cauby Peixoto; Mentirosa (Rutinaldo e Moacyr Silva); Intérprete: Emilinha Borba; A Cara do pai (Lombardi Filho e Pedro Rogério); Intérprete: Ivon Curi; Smiling eyes (Haroldo Eiras); Intérprete: Nancy Montez; Apaga o fogo (Lirio Panicalli); Intérprete: Carequinha e Fred; Canção noturna (Sebastião Gomes); Intérprete: Renato Restier.

\section{DE VENTO EM POPA}

Rio de Janeiro, 1957, $35 \mathrm{~mm}, 101 \mathrm{~min}$.

Cia. produtora: Atlântida - Empresa Cinematográfica do Brasil; Direção de produção: Guido Martinelli; Distribuição: UCB (União Cinematográfica Brasileira); Argumento: Cajado Filho; Roteiro: Cajado Filho; Direção: Carlos Manga; Continuidade: Arlete Lester; Direção de fotografia: Ozen Sermet; Sonografia: Aloísio Viana; Montagem: Waldemar Noya; Dir. Arte/Cenografia: Cajado Filho; Música: Alexandre Gnatalli. 
Elenco/personagens: Oscarito (Chico); Cyll Farney (Sérgio); Sônia Mamede (Mara); Doris Monteiro (Lucy); Margot Louro (Luiza); Zezé Macedo (Mme. FruFru); Nelson Vaz (Tancredo); Eloína (Empregada); Abel Pêra (Médico); Vicente Marchelli; Ribeiro Fortes; Nélson Fortes; Grijó Sobrinho; Carlos Imperial; Francisco Carlos; Antônio Smith; Luiz Carlos Braga.

Canções: Tem que rebolar (José Batista e Magno de Oliveira); Intérprete: Oscarito e Sônia Mamede; Dó, ré, mi (Fernando César); Intérprete: Doris Monteiro; Mocinho bonito (Billy Blanco); Intérprete: Doris Monteiro; Calypso rock; Intérprete: Sônia Mamede e Oscarito.

Prêmios: Prêmio de Melhor Fotografia para Ozen Sermet e de Melhor Produção no Festival do Distrito Federal, 5, 1957, RJ.. Prêmio de Melhor Filme Brasileiro de 1957 eleito pela crítica do Rio de Janeiro.

\section{GAROTAS E SAMBA}

Rio de Janeiro, 1957, $35 \mathrm{~mm}, 102 \mathrm{~min}$.

Cia. produtora: Atlântida - Empresa Cinematográfica do Brasil; Distribuição: UCB (União Cinematográfica Brasileira); Argumento: Cajado Filho; Roteiro: Cajado Filho; Direção: Carlos Manga; Assistência de direção: Sanin Cherques; Direção de fotografia: Edgard Eichorn; Sonografia: Aloísio Viana; Montagem: Waldemar Noya; Dir. Arte/Cenografia: Cajado Filho. 
Elenco/personagens: Renata Fronzi (Naná); Adelaide Chiozzo (Didi); Sônia Mamede (Zizi); Francisco Carlos; Zé Trindade; Jece Valadão; Zezé Macedo (Inocência); Pituca; César Ladeira; Teresinha Morango; Grijó Sobrinho; Suzy Kirby (Jocelina); Berta Loran; Ivon Curi (Charlô); José Melo; Nora Ney; Ruy Rey; Jorge Goulart; Emilinha Borba; Joel de Almeida; César de Alencar; Isaurinha Garcia; Francisco Carlos; Venílton Santos; Ator Convidado: Cyll Farney.

Canções:Vou mandar meu filho pra Paris; Intérprete: Joel de Almeida; Marchinha do piche (Haroldo Lobo e Ivo Santos); Intérprete: César de Alencar; Se o negócio é sofrer (Mário Lago e Chocolate); Intérprete: Nora Ney; Encosta a cabeça no meu rosto; Intérprete: Isaurinha Garcia; Está na hora da onça beber água; Intérprete: Isaurinha Garcia; Não pense em me abandonar; Intérprete: Francisco Carlos.

\section{O CAMELÔ DA RUA LARGA}

Rio de Janeiro, 1958, $35 \mathrm{~mm}, 81 \mathrm{~min}$.

Cia. produtora: Cinedistri - Produtora e Distribuidora de Filmes do Brasil; Produção: Oswaldo Massaini; Distribuição: Cinedistri - Produtora e Distribuidora de Filmes do Brasil; Argumento: Francisco Anísio; Zé Trindade; Roteiro: Victor Lima; Direção: Eurides Ramos; Coreografia: Helba Nogueira; Direção de fotografia: Hélio Barrozo Netto; Direção de som: Alberto Viana; Roteiro de 
montagem: Hélio Barrozo Netto; Dir. Arte/Figurinos: Pedro Ivan;Cenografia: Alcebíades Monteiro Filho; Orquestração: Radamés Gnatalli.

Elenco/personagens: Zé Trindade (Vicente); Maria Vidal (Dona Bébé); Renato Restier (Geraldão); Nancy Wanderley (Aurora); Zezé Macedo (Possidônia); Humberto Catalano (Totó); Teresinha Amayo (Nancy); Mara di Carlo (Alice); Eloína (Virgínia); Allan Lima (Fernando); Wilson Grey (Gringo); Rodolfo Arena (Rafael); Aguinaldo Rocha; Armando Nascimento (Joaquim); Rosa Sandrini (Geraldina); João Péricles (Investigador); Virginia Moreira;Rafael Pellegrini; Virginia da Conceição (Sidósia); Myriam (Myrian).

Canções: Ouça (Maysa); Intérprete: Maysa; Escultura (Adelino Moreira e Nelson Gonçalves); Intérprete: Nelson Gonçalves; Fantasia internacional (M. Guimarães); Música: Vicente Paiva; Intérprete: Julie Joy; $O$ que é que Copacabana tem (M. Guimarães); Música: Vicente Paiva; Intérprete: Eloína.

\section{VOU TE CONTÁ}

São Paulo, 1958, 35 mm, 90 min.

Cia. produtora: Columbia; Companhia Cinematográfica Maristela; Produção: Mário Marinho; Alfredo Palácios; Direção de produção: Ary Fernandes; Distribuição: Columbia Pictures; Argumento: Alfredo Palácios; Roteiro: Cláudio Petraglia; Glauco Mirko Laurelli; Diálogos: Cláudio Petraglia; Glauco Mirko 
Laurelli; Estória: Baseada na peça “O Filho do rei do prego” de Gastão Tojeiro; Direção: Alfredo Palácios; Continuidade: Geny Santos; Direção de fotografia: Rodolfo Icsey; Direção de som: Konstantin Tkaczenko; Montagem: Maria Guadalupe; Edição: Maria Guadalupe; Dir. Arte/Cenografia: José Pereira da Silva.

Elenco/personagens: Pagano Sobrinho; Francisco Negrão; Luely Figueiró; Dorinha Duval; Cinderela; Chocolate; José Mercaldi; Gaetano Gherardi; Neide Pavani; Oswaldo de Souza; Doca; Júlio Ramler; Henrique Cesar; Luiz Campos; Fernando Vicente - Nenê; Walter - Nenê; Virgínia Lane - vedete do Brasil; Dalva de Oliveira; João Dias; Jorge Veiga; Carmen Costa; Risadinha; Ballet de Cid Paes de Barros; Michel Barbane; Isaura Garcia; Ronald Golias; Francisco Egídio; Demônios da Garôa; Milton Paz; Escola de Samba de Herivélto Martins; Escola de Samba de Henricão; Henrique da Costa; Participação especial: Milton Ribeiro; Maria Vidal.

Músicas: O Circo vem aí (José Roy e Francisco Neto); Macaco não (Mirabeau; Don Madrid e Rutinaldo); Jurei por Deus (Gomes Cardim e José Roy); Faladô passa mal (Haroldo Lobo e Milton de Oliveira); Juventude transviada (Malfitano e Frazão); Ingratidão (Afrânio Borba e Tânio Jairo); Mão de Gato (Isaurinha Garcia); Engole êle, paletó (J. Audi); Mamãe já vem aí (Nelson Castro e J. Batista); Cinco letras (J. Nunes; B. e Santos Lobo); Terreque, terreque (Raguinho Avaré e Adoniran Barbosa); Belezas do Rio (Gomes Cardin e Lela); Piripaque (Wilson Vanny; M. Pó e Abreu); Engole êle, paletó; Mão de gato; Mamãe já vem 
aí; Cinco letras; Terreque, terreque; Belezas do Rio; Piripaque; Alvorada. Música de: Brinquinho e Brioso.

Canções: Marcha da banana; Intérprete: Carmen Costa; Quem não conhece o Rio; Intérprete: Dalva de Oliveira; Harém do Maomé; Intérprete: Demônios da Garoa; Quem é que não chora; Intérprete: Francisco Egydio; Engole este paletó; Intérprete: João Dias; Telefonando; Intérprete: Jorge Veiga; Juventude Transviada; Intérprete: Nilton Paz; Alegria de Palhaço; Intérprete: Risadinha; Minha bandolinha; Intérprete: Ronald Golias; A Mamãe vem aí; Intérprete: Virgínia Lane.

\section{GAROTA ENXUTA}

Rio de Janeiro, 1959, 35 mm, $102 \mathrm{~min}$.

Cia. produtora: Herbert Richers - Produções Cinematográficas; Produção: Herbert Richers; Arnaldo Zonari; J. B. Tanko; Distribuição: Distribuidora de Filmes Sino; Argumento: J. B. Tanko; Francisco Anísio; Roteiro: Franciso Anísio; J. B.Tanko; Estória: Estória de: Herbert Richers e J. B. Tanko; Direção: J. B. Tanko; Coreografia: Edmundo Carijó; Direção de fotografia: Amleto Daissé; Direção de som: Alberto Vianna; Montagem: Rafael Justo Valverde; Roteiro de montagem: Rafael Justo Valverde; Dir. Arte/Figurinos: Modas Cabana; Trilha musical: Remo Usai; Orquestra: Remo Usai. 
Elenco/personagens: Ankito (Popó); Grande Otelo (Otelo); Renato Restier (Dr. Lacosta); Nelly Martins (Nelly); Agnaldo Rayol (Rafael); Carlos Costa (Baltazar); Lílian Fernandes (Walquiria); Iracema de Alencar (Vovó); Zequinha \& Quinzinho (Cosme e Damião); Carlos Mello (César); Milton Carneiro; Nick Nicola; Carlos Imperial; R. Furtado; Armando Ferreira; Carlos Henrique; Chiquinho; José Silva; Lia Mara; José Francisco Braga; Mendez; Mozael Silveira; Patrícia Laura; Paulo Rodrigues; Paulo Celestino; Pedro Farah; Riva Blanche; Rodolfo Carvalho; Telma Elita; Participação especial: Jayme Costa (Presidente Falcão); Renata Fronzi; Elizete Cardoso; Carminha Mascarenhas; Vera Regina; Trio Marangatu ; Zezé Gonzaga.

Canções: Nem sol, nem luz, nem paz (Fernando Cesar e Otelo Zuzzolo); Intérprete: Agostinho dos Santos; Em meus braços (Irany de Oliveira e Almeida Rêgo); Intérprete: Emilinha Borba; Sai menina (Ivon Curi); Intérprete: Ivon Curi; No bico da chaleira (Juca Storoni); Intérprete: Trio Irakitan; Touradas em Madrid (João de Barros e Alberto Ribeiro); Intérprete: Trio Irakitan; Eva querida (Benedito Lacerda e Luiz Vassalo); Intérprete: Grande Otelo e Vera Regina; Oh! Filomena (Cancioneiro popular); Intérprete: Grande Otelo e Vera Regina; Marcha do grande galo (Lamartine Babo e Paulo Barbosa); Intérprete: Grande Otelo e Vera Regina; Quebra, quebra gabiroba (Cancioneiro popular); Intérprete: Grande Otelo e Vera Regina; Teu cabelo não nega (Lamartine Babo); Intérprete: Grande Otelo; V. Regina e Carijó; Só faltava ela (Grande Otelo); Intérprete: Nelly Martins e Agnaldo Rayol; Luar de Paquetá (Freire Jr. e Hermes Fontes); 
Intérprete: Nelly Martins e Agnaldo Rayol; Pelas estradas do tempo (Grande Otelo); Intérprete: Nelly Martins; Agnaldo Rayol; Grande Otelo e Vera Regina; Conselho (Denys Brian e Guilherme); Intérprete: Morgana; No morro da Mangueira (Manoel Dias); Intérprete: Marion; Quem não gosta (Remo Usai e Israel Sattini); Intérprete: Iris Bruzzi; Pirata da perna de pau (J. de Barro e Alberto Ribeiro); Intérprete: Nuno Roland; Mamãe eu quero (Vicente Paiva e Jararaca); Intérprete: Jararaca; Qual a razão (Alceu Tunes); Intérprete: Rynaldo Calheiros; Fala quem quiser (Irmãos Orlando); Intérprete: Zequinha e Quinzinho; É bom parar (Nassara e Rubens Soares); Intérprete: Moreira da Silva; Lig-lig-lé (Oswaldo Santiago e Paulo Barbosa); Intérprete: Sylvio Jr.; Jardineira (Benedito Lacerda e Humberto Porto); Intérprete: Orlando Silva; Conjunto e banda: Conjunto Rancho Almeidinha; Instrumentista: Thelma Elita(solista); Instrumentista: Edmundo Carijó (solista).

\section{MASSAGISTA DE MADAME}

Rio de Janeiro, 1959, $35 \mathrm{~mm}, 92 \mathrm{~min}$.

Cia. produtora: Herbert Richers - Produções Cinematográficas; Produção: Herbert Richers; Direção de produção: Murilo Lopes; Distribuição: Fama Filmes; Argumento: Victor Lima; Roteiro: Victor Lima; Direção: Victor Lima; Coreografia: Blanche Mur; Direção de fotografia: Amleto Daissé; Engenharia de som: José Tavares; Nelson Ribeiro; Montagem: Rafael Justo; Roteiro de 
montagem: Rafael Justo; Dir. Arte/Cenografia: Victor Lima; Direção musical: Remo Usai.

Elenco/personagens: Zé Trindade; Renata Fronzi; Costinha; Nancy Wanderley; Aída Campos; Iris Bruzzi; Hélio Colona; Milton Carneiro; Rildo Gonçalves; Estelita Bell; Arlindo Costa; Duarte de Moraes; Nick Nicola; Lia Maria; Farnetto; Rosa Sandrini; Lêda Maria; Wilton Franco; José Silva; Carlos Machado e seu show milionário; Marina Marcel; Apresentando: Bob - cachorro; Figurantes:Vavá; Bellini.

Canções: Conjunto e banda: Night and Day; Orquestração: Jean D'Arco; Massagista de madame (Zé Trindade); Bahia com $H$ (Denis Brean); Apito do samba (L. Bandeira); Tangueira (Mariano Mores); Taquito militar (Mariano Mores).

\section{O HOMEM DO SPUTNIK}

Rio de Janeiro, 1959, 35 mm, $100 \mathrm{~min}$.

Cia. produtora: Atlântida Empresa Cinematográfica do Brasil; Produção: Cyll Farney; Diretores de produção: Abel Teixeira Costa e Cyll Farney; Distribuição: UCB (União Cinematográfica Brasileira); Argumento: José Cajado Filho; Roteiro: José Cajado Filho; Direção: Carlos Manga; Direção de fotografia: Ozen Sermet; 
Técnico de som: Aloysio Vianna; Sonografia: Aloysio Vianna; Montagem: Waldemar Noya; Edição: Waldemar Noya; Dir. Arte/Figurinos: Aelson; Cenografia: José Cajado Filho; Música: Radamés Gnatalli; Regente Maestro: Alexandre Gnatalli; Orquestração: Alexandre Gnatalli; Canção-título: Mademoiselle Bebé; Autor da canção: Bruno Marnet.

Elenco/personagens: Oscarito (Anastácio Fortuna); Cyll Farney (Nelson/Jacinto Pouchard); Zezé Macedo (Cleci Fortuna); Neide Aparecida (Dorinha/namorada de Nelson); Alberto Perez (Alberto/Repórter); Norma Bengell (BB); Heloísa Helena (Dondoca); Hamilton Ferreira (Chefe dos espiões soviéticos); Jô Soares (Espião americano); Geraldo Gamboa; João Labanca; Diego Cristian; Gilberto Luiz; César Viola; Ernesto Braga; Nestor Montemar; Abdias Nascimento; Abel Pêra; Fregolente; Grijó Sobrinho; Hilton Gomes; Joméri Pozzolli; Laura Galano; Maria Acyr; Denys Grey; Riva Blanche; Sergio Roberto; Tutuca.

Prêmios: Prêmio da Associação Brasileira dos Cronistas Cinematográficos de Melhor Atriz Secundária para Norma Bengell, 1959, RJ; Prêmio de Melhor Diretor e Melhor Argumento, para José Cajado Filho, no Festival do Distrito Federal, 1959, RJ.

\section{MARIDO DE MULHER BOA}

Rio de Janeiro, 1960, $35 \mathrm{~mm}, 102 \mathrm{~min}$. 
Cia. produtora: Herbert Richers - Produções Cinematográficas; Direção de produção: José Silva; Distribuição: Distribuidora de Filmes Sino; Argumento: Cajado Filho; Roteiro: J. B. Tanko; Diálogos: Edgar G. Alves; Cajado Filho; Diálogos adicionais: Zé Trindade; Estória: Baseada em história original de J. B. Tanko e Herbert Richers; Direção: J. B. Tanko; Coreografia: Edmundo Carijó; Direção de fotografia: Roque Funes; Direção de som: Nelson Ribeiro; José Tavares; Montagem: Rafael Justo Valverde; Dir. Arte/Acessórios de Cenografia: Ademir Nascimento; Direção musical: Lírio Panicalli; Orquestra: Carlos Monteiro de Souza e Orquestra.

Elenco/personagens: Zé Trindade (Anacleto); Otelo Zeloni (Frederico); Renata Fronzi (Arminda); Renato Restier (Leal); Lilian Fernandes (Sofia); Luely Figueiró (Sueli); Paulette Silva (Marlene);Wilson Grey (Tenório); Celso Faria (Sérgio); Isa Rodrigues (Virgínia); Darcy de Souza (Augusta); Billy Davis (Homem rude); Geraldo Alves (Técnico de TV); Cézar Viola (Giovanni); Paulo Rodrigues (Luiz); Lys Marques (Mário); Adélia Mercadelli (Modelo); Anneliese (Modelo); Ana Maria Soeiro (Modelo); Bernadette Cunha (Modelo); Helena Sanches (Modelo); May Marcinelli (Modelo); Maria Cristina (Modelo); Brigitte Blair (Recepcionista); Dilma Cunha (Vendeuse); Maria May (Vendeuse); Mary Doll (Vendeuse); Maria Luiza (Vendeuse); Edna Wanderley (Recepcionista); Léa de Almeida (Costureira); Lina Cunha (Costureira); Susy Montel; Agnaldo Rocha; Milton Villar; Yara Jety; Diana Eisoelo; Francisco Siciliano; Jacy de Souza; Joel Rosa; Suzette Leclair. 
Canções: Se é tarde me perdôa (Ronaldo Bôscoli e Carlos Lira); Intérprete: Silvinha Teles; $A$ Vizinha do lado (Dorival Caymi); Intérprete: Lúcio Alves; Kanimambo (A. Fonseca; R. Ferreira e M. Siqueira); Intérprete: Aracy Costa; Por quem sonha Ana Maria (Juca Chaves); Intérprete: Juca Chaves; O Relógio da saudade (Sérgio Ricardo); Intérprete: Luely Figueiró; Beijo quilométrico (Zé Trindade e Walter Levita); Intérprete: Zé Trindade; Mademoiselle Paris (Lírio Panicalli); Intérprete: Lilian Fernandes; Minha inspiração (Raul de Barros); Orquestração: Orquestra Raul de Barros; Intérprete: Lúcio Alves; Regente: Carlos Monteiro de Souza.

\section{VAI QUE É MOLE}

Rio de Janeiro, 1960, $35 \mathrm{~mm}, 102 \mathrm{~min}$.

Cia. produtora: Herbert Richers - Produções Cinematográficas; Produção: Herbert Richers; Arnaldo Zonari; J. B. Tanko; Direção de produção: Murilo Lopes; Distribuição: Herbert Richers - Produções Cinematográficas; Argumento: J. B. Tanko; Roteiro: J. B. Tanko; Diálogos: J. B. Tanko; Edgar G. Alves; Direção: J. B. Tanko; Coreografia: Helba Nogueira; Direção de fotografia: Amleto Daissé; Direção de som: Nelson Ribeiro; José Tavares; Edição: Rafael Justo Valverde; Arranjos musicais: Carlos de Souza Barros; Direção musical: Lyrio Panicalli. 
Elenco/personagens: Ankito (Macio); Grande Otelo (Brancura); Renata Fronzi (Repórter); Anilza Leoni (Lea); Renato Restier (Padre); Otelo Zeloni (Gianini); Pedro Dias (Médico); Armando Ferreira (Comendador); Jô Soares (Bolinha); Carlos Imperial (Pé de Cabra); Carlos Costa (Mordomo); Maria Augusta (Maisa); Aurino Cassiano (Zé Maria); Paulo Rodrigues; Luiz Mazzei; Adolfo Machado; Liz Marques; Jefferson Dantas; Farnetto; Tarcísio Zanotta; Milton Leal; Tony Júnior; lara Jaty; Tânia Martins; Balé Folclórico de Mercedes Batista; Adail Viana; Amado de Arimatheia; Antonio Nascimento; Berlinck Silva; Carmen Célia; Ilda Restier; Jorge Felipe; José Lopes; Martha Cristina; Nilo Pinheiro; Rodolfo Berghirchner; Silvio Bitencourt; Walter Goulart; Yolanda Moura; Participação especial: Aurélio Teixeira(Dureza).

Canções: Eu e o samba (Nelson Castro); Intérprete: Virgínia Lane; Mineiro sabido (Luiz Wanderley e Elias Soares); Intérprete: Luiz Wanderley; Quero me casar (Hugo Brando e Pedro Almeida); Intérprete: Hugo Brando; Eu quero é beijar (Carlos Imperial e Wilson Simonal); Intérprete: Ankito e Anilza Leoni; Morena Guanabara (A.Pinto e Grande Otelo); Intérprete: Grande Otelo e Maria Augusta; Ladrões de corações (A.Pinto e Grande Otelo); Intérprete: Ankito; Jô Soares; Maria Augusta e Grande Otelo.

\section{O DONO DA BOLA}

Rio de Janeiro, 1961, 35 mm, 90 min. 
Cia. produtora: Herbert Richers - Produções Cinematográficas; Produção: Herbert Richers; Direção de produção: Riva; Distribuição: Fama Filmes; Argumento: J. B. Tanko; Roteiro: J. B. Tanko; Diálogos: Mário Meira Guimarães; Estória: Baseada em idéia de: Meira Guimarães; Direção: J. B. Tanko; Coreografia: David Dupré; Direção de fotografia: Amleto Daissé; Técnico de som: José Tavares; Nelson Ribeiro; Montagem: Rafael Justo Valverde; Dir. Arte/Cenografia: AlexandreHorvath; Música: Lírio Panicalli.

Elenco/personagens: Ronald Golias (Bronco); Norma Blum (Eva); Vera Regina (Josefina Fitzgelo e Clarinha); Costinha (Arquibaldo); Carlos Imperial (Ronaldo); Perry Salles (Fernando); Armando Nascimento (Dono do supermercado); César Viola (Perpétuo); Luiz de Carvalho (Animador do programa); Valença Filho; Hélio Colona; Pedro Dias; Mozael Silveira; Billy Davis; Adélia lório; Waldemar Sujeira; Pedro Veiga Faria; Suzy Montel; Yara Jaty; Lyz Marques; Kátia Gestal; Martha Lamur; Walter Araújo; José Silva; Maria Cristina; Jaqueline Olivier; José Maia; Francisco Siciliano; Shirley de Araújo; Marly Tavares - solista no número de dança; Participação especial: Grande Otelo.

Músicas: Barão do Rio Branco; Música: Francisco Braga; Alvorada; Música: Oswaldo Passos Cabral; Cisne branco; Música: Antônio do Espírito Santo e Benedito Xavier de Macedo; 
Canções: Alta sociedade (Meira Guimarães); Música: Lirio Panicalli; Intérprete: Grande Otelo e Vera Regina; Chá chá chá (Lirio Panicalli); Intérprete: Grande Otelo e Vera Regina.

\section{TRÊS COLEGAS DE BATINA}

Rio de Janeiro, 1961, 35 mm, 103 min.

Cia. produtora: Cinedistri - Produtora e Distribuidora de Filmes do Brasil; Produção: Oswaldo Massaini; Watson Macedo; Direção de produção: Elias Lourenço de Souza; Distribuição: Cinedistri - Produtora e Distribuidora de Filmes do Brasil; Argumento: Darcy Evangelista; Roteiro: Darcy Evangelista; Ismar Porto;Estória: Baseada em idéia original de João Costa Neto; Direção: Darcy Evangelista; Continuidade: Eneyd Maria Neiva; Direção de fotografia: Ugo Lombardi; Direção de som: Alberto Viana; Montagem: Watson Macedo; Dir. Arte/Cenografia: Mauro Monteiro.

Elenco/personagens: Trio Irakitan; Eliana (Celina); Herval Rossano (Aloisio); Paulo Roberto (Dr. Pedro); Edmundo Maia (Frei Martinho); Augusto César (Jaime); Renato Murce (Padre Guardião); João Labanca (Frei Xavier); Nelson Vaz (Frei Felipe); Paulo Celestino (Diretor da repartição); Mozael Silveira (Zé Pedro); Telma Elita (Gilda); Valença Filho (Bonfim); Chiquinho (Frei Querubim); Angelito Melo (Alonir); Joel Vaz (Rodolfo); Iara Lex (Luizinha); Armando Ferreira (Alberto Machado); Isa Rodrigues (Mulher da rádio); Renee Brown(Marina); Nelly Costa 
(Esperança); Carmen Montiel (Ruth); Rosa Sandrini (Beatriz); Ronaldo Antunes (Betinho); Mergot Mello (Dulce); Valença Neto (Joãozinho); Shirley Munhoz; Samuel dos Santos; Ariel Dantas; Malena; Arthur Sanches; Augusta Moreira; Sônia Magalhães; Adrian Samoiloff; Rodolfo del Rio; Maravilha; Astorga Nagra; Clelia D'Ávila; Participação especial: Walter D'Ávila; Ari Barroso (Ari Barroso); Catalano (Nagib); Zezé Macedo (Funcionária da Caixa Econômica); Zeloni (Comunista); Abelardo Barbosa (Fotógrafo).

Canções: Semente de amor (Ari Barroso e Luiz Goulart); Música: Renzo Lamberto e Severino Filho; Conjunto e banda: Trio Irakitan; Pior p'ra você (Evaldo Gouveia e Almeida Rego); Música: José Evangelista; Intérprete: Telma Elita; Quem tem fé (Edson França e João Costa Neto); Música: Pedro Virgínio Vistoral; Conjunto e banda: Trio Irakitan; Magnificat (Pedro Virgínio Vistoral); Música: Evaldo Gouveia; Conjunto e banda: Pequenos Cantores da Guanabara; Ave Maria (Renzo Lamberto); Música: Almeida Rego; Conjunto e banda: Trio Irakitan; Nunca mais (João Costa Neto); Música: José Evangelista; Conjunto e banda: Marilda e seu conjunto; Flamengo (Edson França); Intérprete: Telma Elita; Porque sonho (José Evangelista); Música: Luiz Goulart Conjunto e banda: Marilda e seu conjunto;Vamos criança (Edson França e João Costa Neto); Cuore ingrato (Cardillo e Cordiferro); Intérprete: Alexandre Berlucci; São João tem uma gaita; Acorda escoteiro. 
Obs.: O Trio Irakitan era composto por: João Costa Neto; Paulo Gilvan e Edson França, que fizeram os papéis de Padre Geremias, Padre Rafael e Padre Mateus.

\section{VIROU BAGUNÇA}

Rio de Janeiro, 1961, 35 mm, $100 \mathrm{~min}$.

Cia. produtora: Watson Macedo Produções; Cinedistri; Produção: Watson Macedo; Direção de produção: Elias Lourenço de Souza; Distribuição: Cinedistri; Argumento: Watson Macedo; Ismar Porto; Mário Meira Guimarães; Roteiro: Watson Macedo; Ismar Porto; Mário Meira Guimarães; Diálogos: Mário Meira Guimarães; Direção: Watson Macedo; Direção de fotografia: Ugo Lombardi; Direção de som: Alberto Viana; Montagem: Watson Macedo; Dir. Arte/Cenografia: Watson Macedo; Mauro Monteiro; Música: Lírio Panicalli.

Elenco/personagens: Trio Irakitan (Trio Gerimum); Nádia Maria (Marly); Zezé Macedo (Biluca);Valença Filho (Josias); Roberto Duval (Fidelino Granada); Mozael Silveira (Napoleão); Paulo Celestino (Walter); Angelito Mello (Empresário); Abelardo Barbosa (Chacrinha); Átila lório (Detetive); Vicente Marchelli (Médico do hospício); Alberico Bruno (Nero); Adolfo Machado (Ademar); Ayrton Ventura (Primeiro barbudo); Fernando Ramos (Segundo barbudo); Nena Napoli (Vedete de teatro); Rosa Sandrini (Freguesa do restaurante); Gonzaga Vasconcelos (Rapaz da TV); Zé Bacurau (Deputado nordestino); Zé Praxedes (Dr. Kleber); Roberto Yago (Artista de teatro); Ademar Montila (Louco do trio); Tony Jr. (Garçom); Sérgio 
Vieira (Segundo enfermeiro); Olindo Camargo (Freguês); Mário Silva (Freguês); Ronaldo Granado (Boy do teatro); Nicolino Cupello (Diretor de TV); Walter Levita (Professor Bey); Pedro Faria Veiga (Delegado); Jaime Severino; Ilka.

Canções: Eu vim morar no Rio (H. de Almeida e F. Anisio); Intérprete: Carlos Gonzaga; Na hora de sambar (Miguel Gustavo); Intérprete: Francisco Carlos; Brasilina (Ayres Viana e Murilo Vieira); Intérprete: Antonio Carlos; Canção da aranha (Edson França e Costa Netto); Intérprete: Antonio Carlos; Não há (Leduvy de Pina); Almeidinha e Zilda do Zé; Intérprete: Linda Batista; Corocotum (Venancio e Corumba); Intérprete: Carlos Gonzaga; Tenho você (Almeidinha e Carlos Gonzaga); Intérprete: Zilda do Zé; Pensar... professor (José Costa e Fernandinho); Intérprete: Zilda do Zé; Índio quer apito (Aroldo Lobo e M. de Oliveira); Intérprete: César de Alencar; Cantareira (Barbosa da Silva e Eloide Horto); Intérprete: Aracy Costa; Lago dos cisnes (Piotr Ilitch Tchaikovski); Intérprete: Emilinha Borba; Ozébio (Braguinha); Intérprete: Zilda do Zé; Mustafá (Bob Azzam e Eddie Barclay); Intérprete: Emilinha Borba; Não teve graça (Aldacyr Loro e F. Rodrigues); Intérprete: Linda Batista; Quero morrer no carnaval (Luíz Antonio e Eurice Campos); Intérprete: Zilda do Zé; Walter Levita.

Fontes: AUGUSTO, Sérgio. Este mundo é um pandeiro: a chanchada de Getúlio a JK. São Paulo: Companhia das Letras/Cinemateca Brasileira, 1989.

http://www.cinemateca.gov.br/cgibin/wxis.exe/iah/?lsisScript=iah/iah.xis\&base=FILMOGRAFIA\& lang=p\&nextAction=Ink\&exprSearch=016479\&format=detailed.pft, 15:34, 2007. 
